\title{
DANILO STOCCO
}

\section{CARACTERIZAÇÃO DE SOLDA POR RESISTÊNCIA A PONTO ATRAVÉS DE AVALIAÇÕES NÃO DESTRUTIVAS}

Dissertação apresentada à Escola Politécnica da Universidade de São Paulo para obtenção do Título de Mestre em Engenharia Mecânica 


\section{DANILO STOCCO}

\section{CARACTERIZAÇÃO DE SOLDA POR RESISTÊNCIA A PONTO ATRAVÉS DE AVALIAÇÕES NÃO DESTRUTIVAS}

Dissertação apresentada à Escola Politécnica da Universidade de São Paulo para obtenção do Título de Mestre em Engenharia Mecânica

Área de Concentração:

Engenharia Mecânica de Projeto e

Fabricação

Orientador:

Professor Doutor

Gilmar Ferreira Batalha

São Paulo 
Este exemplar foi revisado e alterado em relação à versão original, sob responsabilidade única do autor e com a anuência do orientador.

São Paulo, 16 de Maio de 2010.

Assinatura do autor

Assinatura do orientador

\section{Stocco, Danilo}

Caracterização de solda por resistência a ponto através de avaliações não destrutivas / D. Stocco. -- São Paulo, 2010. $110 \mathrm{p}$.

Dissertação (Mestrado) - Escola Politécnica da Universidade de São Paulo. Departamento de Engenharia Mecatrônica e de Sistemas Mecânicos.

1. Ultrassonografia (Técnicas) 2. Soldagem por ponto 3. Soldagem por resistência 4. Ensaios não destrutivos I. Universidade de São Paulo. Escola Politécnica. Departamento de Engenharia Mecatrônica e de Sistemas Mecânicos II. t. 
A meus pais, Graziano e Beth, pela dedicação de suas vidas pela minha, e pelo caráter e valores que me ensinaram, para que eu pudesse chegar até aqui.

A minha amada esposa Claudia, e a nossa princesa Giulia, pela paciência, compreensão, suporte e alegria de vida que passam todos os dias. Obrigado pela compreensão do significado deste feito na minha vida (E no caminho chegou a Rafaela!).

Que Deus os abençoe e recompense por tudo! 


\section{Agradecimentos}

Ao professor Gilmar Ferreira Batalha, meu orientador, pelo tempo dispensado de suas inúmeras tarefas e pela competência e disponibilidade no paciente ensinamento não só da engenharia, mas da vida, sempre me dando exemplos para que eu perseverasse neste trabalho, especialmente pela atenção, compreensão e confiança.

A Mercedes-Benz do Brasil, pela cessão de material e suporte técnico para realização dos experimentos, em especial a equipe do Centro Tecnológico da Qualidade de Materiais.

Ao grande amigo Valdir Furlanetto, pelo tempo, esforço e incentivo para a conclusão deste trabalho, e auxílio na preparação das amostras.

A General Motors do Brasil, em especial aos colaboradores da Engenharia de Qualidade de Fornecedores, pelo apoio prestado na conclusão deste trabalho após uma transição rápida de empresas.

A Tessonics Corporation, pela permissão de uso de material e utilização do equipamento de ultra-som RSWA para a realização dos experimentos.

Ao Centro Universitário da Fundação Educacional Inaciana (FEI), em especial aos professores Roberto Bortolussi e Rodrigo Magnabosco, pelo apoio concedido desde a graduação, e pela cessão do equipamento para realização dos ensaios de fadiga.

Enfim, a todos que de uma forma ou outra ajudaram a cumprir mais esta etapa da minha vida. 


\section{Resumo}

O objetivo desta dissertação é escrever sobre a técnica de ultra-sonografia, aplicada na inspeção da soldagem por resistência a ponto, e demonstrar as vantagens desta técnica em relação aos ensaios destrutivos convencionalmente normalizados e utilizados na inspeção de solda a ponto até meados de 1999, quando a técnica de ultra-som começou a ser aplicada no Brasil. Para tanto foram realizados dois procedimentos experimentais, sendo o primeiro deles utilizando a técnica de ultrasom a-scan (transdutor de simples elemento), onde foram estudados os efeitos da indentação do ponto de solda, um dos parâmetros que pode ser detectado com extrema facilidade por esta técnica. O segundo experimento visa demonstrar a capacidade de detecção da técnica de ultra-som b-scan (transdutor matricial), onde a metodologia foi aplicada visando correlacionar os resultados obtidos pelo equipamento com os resultados encontrados nas técnicas de arrancamento (peel test) e nos ensaios macrográficos convencionalmente conhecidos. Com estes experimentos, foi possível comprovar a confiabilidade e repetibilidade desta técnica, mostrando uma maior precisão em relação aos ensaios normalizados conhecidos, além da avaliação quantitativa que pode ser feita, tornando possível a coleta estatística de dados. Foi também notada grande dificuldade em interpretar os sinais gráficos emitidos pelos equipamentos, bem como atestar sua confiabilidade e capacidade de detecção de defeitos, surgindo a necessidade de intensificar o treinamento dos operadores desta técnica. De qualquer forma, esta técnica representa o estado da arte na inspeção de solda por resistência, e foi o principal motivador deste estudo. 


\begin{abstract}
The aim is to describe the ultrasound technique, applied to the inspection of the resistance spot welding, and to demonstrate the advantages of this technique over the conventionally standardized destructive tests used in spotweld inspections until mid 1999, when the ultrasound technique began to be applied in Brazil. For this, two experimental procedures were organized, the first using the a-scan (single element transducer) ultrasound technique, in which the effects of the indentation of the spotweld were studied, one of the parameters that can be easily detected by this technique. The second experiment seeks to demonstrate the detection capacity of the ultrasonic b-scan technique (matrix transducer), in which the methodology was applied to seek the correlation between the results obtained by the equipment with the results found in the peel test and also in the macrographic results conventionally known. With these experiments, it was possible to prove the reliability and reproductibility of this technique, showing an increase in precision when related to the normalized known tests, besides the quantitative evaluation that can be made, allowing the statistical collection of data. A great difficulty was also noticed in interpreting the graphic signs emitted by the equipment, as well as in attesting the reliability and capacity of defects detection, raising the need of operators training. In any way, this technique represents the state of the art in the resistance spotweld inspection, and this was the main motivator of this study.
\end{abstract}




\section{Sumário}

Agradecimentos ....................................................................................................................................................... II

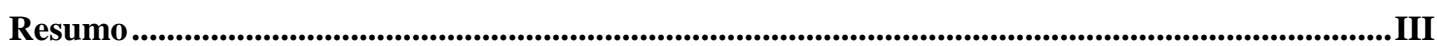

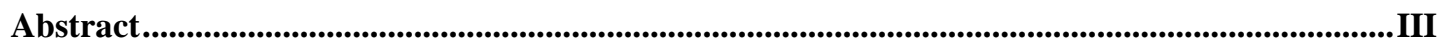

Lista de símbolos .............................................................................................................................. VIII

Índice de Figuras ..............................................................................................................................IX

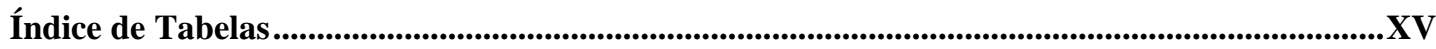

1 Introdução

$2 \quad$ A soldagem por resistência ............................................................................................................. 21

$2.1 \quad$ Definição de soldagem por resistência …………….................................................... 21

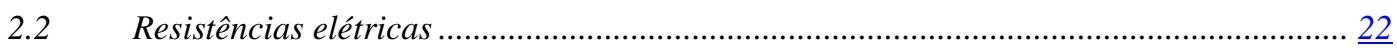

2.3 Formação da lentilha de solda............................................................................. 23

2.4 Distribuição de temperaturas e zonas metalúrgicas ......................................................... 24

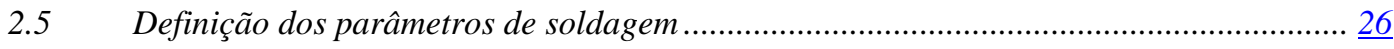

2.5.1 Corrente elétrica ............................................................................................ 2 28

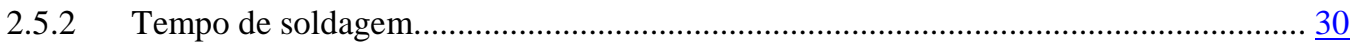

2.5.3 Força entre os eletrodos ......................................................................................... $\underline{30}$

2.5.4 Resfriamento do ponto de solda ………………................................................... $\underline{32}$

2.5.5 Eletrodos para soldagem por resistência a ponto .......................................................... $\underline{32}$

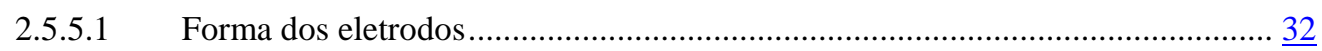

2.5.5.2 Propriedades das ligas utilizadas.................................................................. $\underline{33}$

2.5.5.3 Infuência do estado dos eletrodos ....................................................................... 34

3 Principais defeitos encontrados na soldagem por resistência a ponto.................................... 35

3.1 Ponto solto (Sem fusão, solda fria) …………….....................................................

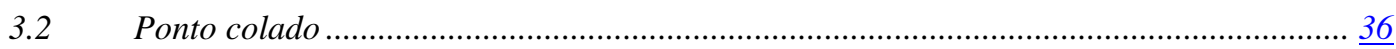

3.3 Lentilha pequena ……………………………......................................................

3.4 Descontinuidade interna (Falha no ponto) ………..................................................... 
4 Ensaios destrutivos aplicados em solda por resistência a ponto ……………………………….... $\underline{42}$

4.1 Ensaio de destacamento por martelo e talhadeira (peel test) ........................................... 42

4.2 Ensaios de Tração............................................................................................... 44

4.3 Ensaios metalográficos ou macrográficos ………………………………………..... $\underline{46}$

$5 \quad$ Método de ensaio por ultra-som .................................................................................................... 48

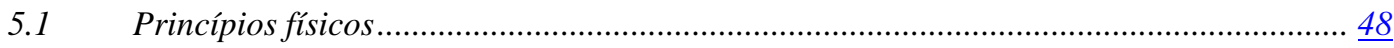

$5.2 \quad$ Efeito piezoelétrico...........................................................................................

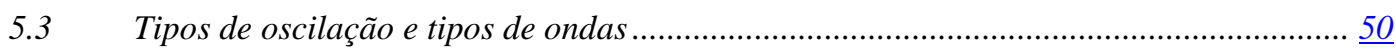

5.3.1 Ondas longitudinais ............................................................................................ 51

5.3.2 Onda transversal (onda de cisalhamento) ............................................................. $\underline{53}$

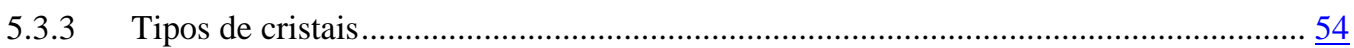

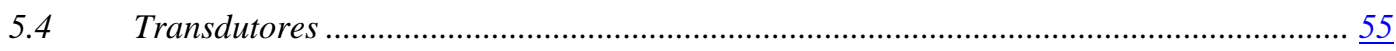

5.4.1 Transdutores normais ou retos...........................................................................

5.4.2 Transdutores angulares .................................................................................. 57

5.4.3 Transdutores duplo-cristal .......................................................................... $\frac{58}{\ldots}$

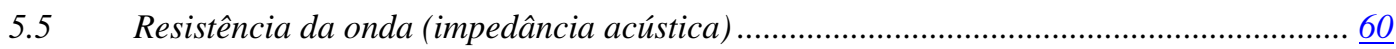

5.6 Técnicas de varredura utilizadas ............................................................................ 61

5.6.1 Técnica de transparência (Through-transmission mode) ........................................... 61

5.6.2 Técnica de impulso-eco / incidência perpendicular (pulse- echo mode) ........................ $\underline{62}$

6 Método de ensaio por ultra-som aplicado a soldagem por resistência a ponto ..................... 67

6.1 Transdutor de simples elemento (A-Scan) .............................................................. $\underline{67}$

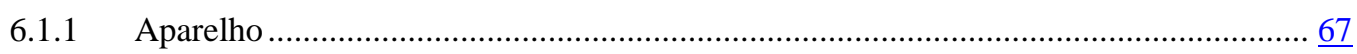

6.1.2 Impulso de transmissão ………………………………………………………………

6.1.3 Imagens de ecos ....................................................................................... 70

6.1.4 Seleção do transdutor adequado ............................................................................ 71

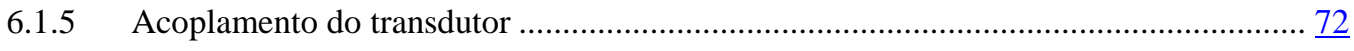

6.1.6 Avaliação de uma junta .................................................................................... $\underline{73}$

6.2 Correlção e interpretação dos sinais apresentados no equipamento a-scan X principais defeitos encontrados na solda por resistência a ponto.............................................................. $\underline{75}$

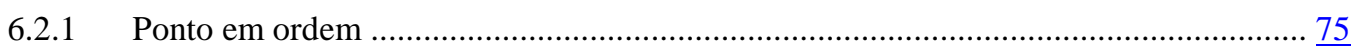

6.2.2 Ponto solto (Sem fusão, solda fria) …………………………………………… 76

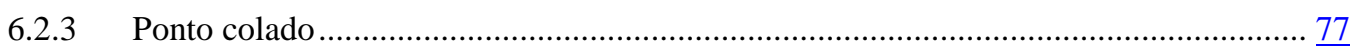


6.2.4 Lentilha pequena / Descontinuidade interna (Falha no ponto) ................................ $\underline{78}$

6.2.5 Excessiva indentação (ponto queimado) …............................................................ 79

6.3 Técnica de ensaio utilizando o transdutor matricial (B-scan) ..................................... $\underline{81}$

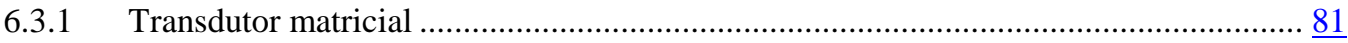

6.3.2 Geração de imagens e interpretação dos resultados................................................ $\underline{82}$

$7 \quad$ Procedimento experimental

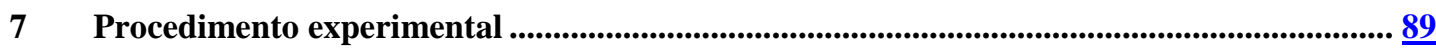

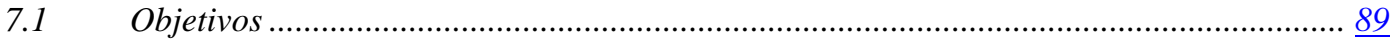

7.2 Utilização de inspeção por ultra-sonografia para aprovação de uniões por solda a ponto submetidas a fadiga ............................................................................................................ 89

7.2.1 Materiais e métodos.......................................................................................... 89

7.2.2 Modelamento pelo método dos elementos finitos ................................................ 93

7.2.3 Resultados e discussão …............................................................................. 97

7.3 Correlação entre os ensaios de ultra-som 2D, quando comparados ao ensaio de destacamento e os ensaios metalográficos ................................................................................ 100

7.3.1 Materiais e métodos............................................................................................ 100

7.3.2 Resultados e discussão …............................................................................. 102

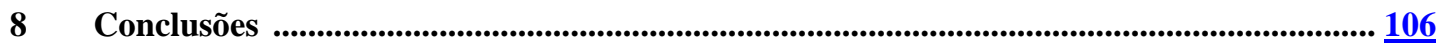

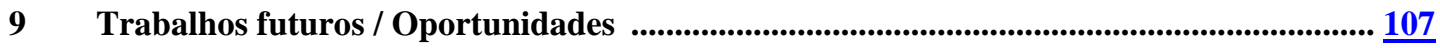

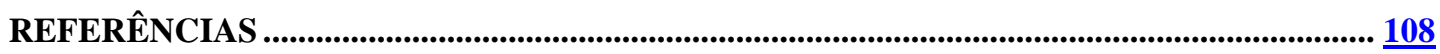




\section{Lista de símbolos}

Q

E

I

$\mathrm{R}$

e

$\mathrm{t}$

$\sigma$

$\sigma \mathrm{u}$

$\sigma \mathrm{e}$

1

Z

$\rho$

$\mathrm{v}_{\mathrm{T}}$

$\mathrm{V}_{\mathrm{L}}$

d

f
Calor gerado na solda

Módulo de elasticidade

Intensidade de Corrente de Solda

Resistência elétrica

Espessura da chapa

Tempo de aplicação da corrente

Tensão aplicada

Limite de resistência à tração

Limite de escoamento

Comprimento do corpo de prova

Impedância

$\left[\mathrm{kg} / \mathrm{m}^{2} \mathrm{~s}\right]$

Densidade do meio

$\left[\mathrm{kg} / \mathrm{m}^{3}\right]$

Velocidade de propagação da onda transversal

Velocidade de propagação da onda longitudinal

Diâmetro do ponto de solda

Frequência do transdutor $[\mathrm{m} / \mathrm{s}]$

$[\mathrm{m} / \mathrm{s}]$

$[\mathrm{mm}]$

$[\mathrm{J}]$

$[\mathrm{MPa}]$

$[\mathrm{mm}]$

[ciclos]

[MPa]

$[\mathrm{MPa}]$

$[\mathrm{MPa}]$

$[\mathrm{mm}]$

$[\mathrm{Hz}]$ 
Ds

Diâmetro do transdutor

[mm]

omed $_{\mathrm{VM}}$

$\sigma_{\max }$
Tensão média de Von Mises

[MPa

Tensão máxima principal
[MPa] 


\section{Índice de Figuras}

Figura 1 : Reclamação de cliente registrada em revista, referente a problemas em ponto de solda (Autoesporte, 2003).

Figura 2 : Reclamação de cliente registrada em revista, referente a problemas em ponto de solda (Quatro Rodas, 1998).

Figura 3 : Resistências Elétricas. 22

Figura 4: Esquema do processo de soldagem. 24

Figura 5: Distribuição de temperaturas.

Figura 6: Estrutura esquemática de uma lentilha de solda solidificada considerando resfriamento ideal e uniforme (ZHANG, 2005). 25

Figura 7: Seção transversal de um ponto soldado mostrando região fundida e zonas termicamente afetadas, ataque nital 2\%, 50X (STOCCO, 2003) 25

Figura 8: Perfil de recondicionamento de eletrodos (DaimlerChrysler,2002). 29

Figura 9: Senoidal representando 1 ciclo de corrente de solda (FURLANETTO,2005).

Figura 10: Formação de rebarba e deformação da lentilha devido à excessiva força entre os eletrodos. (DaimlerChrysler,2002). 31

Figura 11: Sistema de refrigeração dos eletrodos (MEDAR, 2004 - modificado).....32

Figura 12: Seção transversal de eletrodo de liga $\mathrm{Cu}$-Cr, com $200 \mathrm{X}$ de aumento (DaimlerChrysler,2002).

Figura 13: Microestrutura do material base da chapa a ser soldada, 100X .35

Figura 14: Microestrutura da região soldada após aquecimento, mostrando alteração térmica, porém sem a formação de lentilha soldada, 100X..... .36

Figura 15: Seção transversal mostrando ponto de solda colado, ataque nital 2\%, 40X (DaimlerChrysler,2002). .36

Figura 16: Seção transversal mostrando ponto com diâmetro abaixo do especificado, ataque nital 2\%, 40X (STOCCO, 2003)......

Figura 17: Seção transversal mostrando ponto de solda com descontinuidade interna, ataque nital 2\%, 40X (DaimlerChrysler,2002). .38

Figura 18: Seção transversal mostrando ponto de solda com indentação excessiva, ataque nital 2\%, 40X (STOCCO, 2003). 
Figura 19: Detalhe da superfície do ponto de solda apresentando trincas superficiais (STOCCO, 2001)

Figura 20: Seção transversal mostrando microtrincas na superfície do ponto de solda, ataque nital 2\%, 200X (STOCCO,2001)..... .40

Figura 21: Seção transversal mostrando microtrinca na superfície do ponto de solda com incrustação de material base do eletrodo utilizado para a soldagem, ataque nital $2 \%, \quad 500 X$

(STOCCO, 2001) 41

Figura 22: (a) Ilustração do ensaio de destacamento (peel test). (b) medições a serem efetuadas no caso de lentilha assimétrica. (c) localização e forma de medição ( $G M$, 2006) .43

Figura 23: Corpo de prova após o ensaio de destacamento. .44

Figura 24: Ensaio de tração realizado em ponto de solda. 45

Figura 25: Seção transversal mostrando ponto com diâmetro abaixo do especificado, ataque nital 2\%, 40X (STOCCO, 2003).....

Figura 26: Principais medidas de uma seção transversal de um ponto de solda (DIN 14329, 2003).

Figura 27: Efeito piezoelétrico (ABENDI, 2008)

Figura 28: Modelo plano de um corpo sólido (ALICH, 2001). .50

Figura 29: Representação do deslocamento da onda longitudinal (LEITE, 1977)...51

Figura 30: Representação do deslocamento da onda transversal (LEITE, 1977).......53

Figura 31: Representação do campo sonoro (ALICH, 2001)....................................56

Figura 32: Transdutor normal ou reto (ABENDI, 2008)...........................................57

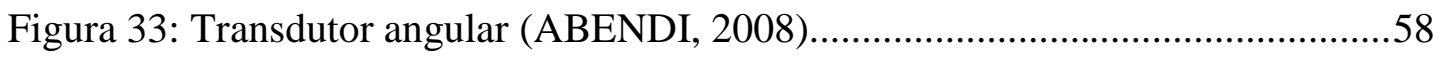

Figura 34: Transdutor duplo-cristal (ABENDI, 2008)...........................................59

Figura 35: Técnica da transparência (ABENDI, 2008).........................................61

Figura 36: Imagem ultra-sônica sem falha (ALICH, 2001)......................................63

Figura 37: Imagem ultra-sônica com descontinuidade (ALICH, 2001)....................64

Figura 38: Imagem ultra-sônica sem eco de superfície limite (ALICH, 2001)..........64

Figura 39: Imagem ultra-sônica com várias descontinuidades (ALICH, 2001)..........65

Figura 40: Imagem ultra-sônica sem ecos de descontinuidade nem ecos de superfície limite (ALICH, 2001).. 
Figura 41: Ecos múltiplos (ALICH, 2001) .66

Figura 42: Estrutura esquemática de um aparelho analógico de controle ultra-sônico (KRAUTKRAMER, 2007). .68

Figura 43: Criação de ecos fantasmas no caso de sequência de impulsos inadequada

Figura 44: Representação do impulso de transmissão (ALICH, 2001)......................70

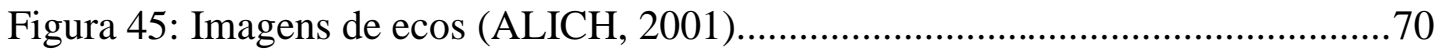

Figura 46: Perfil do feixe sonoro, ilustrando a aplicação da coluna d'água................71

Figura 47: Estrutura do transdutor especial para controle de solda a ponto (ALICH, 2001) .72

Figura 48: Aplicação de um transdutor especial........................................................73

Figura 49: Imagem de sinal ultra-sônico (a-scan)...................................................73

Figura 50: Distâncias sonoras num ponto de solda (ALICH, 2001)...........................74

Figura 51: Imagem ultra-sônica representando ponto em ordem..............................76

Figura 52: Imagem ultra-sônica representando a medição de uma única chapa..........77

Figura 53: Imagem ultra-sônica representando a medição de um ponto colado..........78

Figura 54: Imagem ultra-sônica representando indicações de eco intermediárias na junta soldada, características de uma lentilha pequena ou descontinuidade interna no ponto.

Figura 55: Imagem ultra-sônica representando indicações de eco características de um ponto queimado. .80

Figura 56: Imagem ampliada de um transdutor matricial (DENISOV, 2004). . .82

Figura 57: Representação do percurso sonoro dentro da amostra e a representação do sinal correspondente (DENISOV, 2004)...... .83

Figura 58: Imagem a-scan e respectiva representação b-scan na tela do equipamento

Figura 59: Imagem da tela do equipamento, mostrando a imagem gerada (A), e o respectivo sinal a-scan $(\mathrm{B})$.

Figura 60: Imagem de uma região soldada, obtida com o transdutor matricial sem interpolação (esquerda), e após interpolação (direita). Cada célula cobre $1 \mathrm{~mm}^{2}$ de área (DENISOV, 2004). .86 
Figura 61: Ensaios de correlação apresentando comparação entre diversos diâmetros de ponto medidos através do RSWA X medição real do ponto através de microscopia (a) $0.8 \mathrm{~mm}$ - (DENISOV, 2004 - modificado)

Figura 62: Ensaios de correlação apresentando comparação entre diversos diâmetros de ponto medidos através do RSWA X medição real do ponto através de microscopia (b) $1.0 \mathrm{~mm}$ - (DENISOV, 2004 - modificado)

Figura 63: Ensaios de correlação apresentando comparação entre diversos diâmetros de ponto medidos através do RSWA X medição real do ponto através de microscopia (c) $1.2 \mathrm{~mm}$ - (DENISOV, 2004 - modificado). .88

Figura 64: Ensaios de correlação apresentando comparação entre diversos diâmetros de ponto medidos através do RSWA X medição real do ponto através de microscopia (d) $1.8 \mathrm{~mm}$ - (DENISOV, 2004 - modificado) . .88

Figura 65: Junta soldada em estudo e geometria do ponto de solda..... .90

Figura 66: Máquina universal de ensaios MTS do LabMat - FEI. .91

Figura 67: Curva tensão X deformação para as juntas estudadas..... . .92

Figura 68: Aspecto do corpo de prova fraturado após ensaios de tração. .93

Figura 69: Resultados da simulação via MEF para a tensão principal máxima $\left(\sigma \max _{\mathrm{PR}}=\sigma \operatorname{med}_{\mathrm{PR}}+\Delta \sigma_{\mathrm{PR}}\right)$ com elementos planos, mostrando as áreas de concentração de tensão nos pontos mais externos . .95 Figura 70: Resultados da simulação via MEF para a tensão de von Mises com elementos planos, mostrando as áreas de concentração de $\Delta \sigma \mathrm{VM}$ nos pontos mais externos da chapa.

Figura 71: Variação das componentes da tensão principal máxima em função da indentação do ponto de solda. Resultado da simulação via MEF com elementos sólidos.

Figura 72: Comprovação experimental: surgimento de trinca na região da tensão de von Mises máxima.. .96

Figura 73: Aspecto do corpo de prova fraturado após o ensaio cíclico. .97

Figura 74: Microscópio Eletrônico de Varredura (MEV) com 37,4 vezes de aumento, onde a região $\mathrm{A}$ demonstra a quebra inicial por fadiga, enquanto que a região $\mathrm{B}$ mostra a quebra final brusca. .98 
Figura 75: Microscópio Eletrônico de Varredura (MEV) com 2500 vezes de aumento, mostrando detalhe da região A, evidenciando estrias de fadiga..............98 Figura 76: Microscópio Eletrônico de Varredura (MEV) com 2500 vezes de aumento, mostrando detalhe da região B, evidenciando fratura alveolar, característica de uma quebra dúctil. .99 Figura 77: Correlação entre ensaios realizados através do equipamento RSWA X diâmetro aferido durante ensaios destrutivo de martelo e talhadeira. 103 Figura 78: B-scan das amostras 1 e 8, apresentando indicação de provável descontinuidade interna, sinalizada pelas setas 104 Figura 79: Metalografia da amostra 1, apresentando indicação de descontinuidade interna, confirmando o exame ultra-sônico, ataque nital 2\%, 50X de aumento......104 


\section{Índice de Tabelas}

Tabela 2.1: Ligas de cobre utilizadas par a confecção dos eletrodos para soldagem por pontos.

Tabela 4.1: Parâmetros de resistência da solda por resistência a ponto (GM, 2002).45

Tabela 7.1: Composição química do aço em estudo (\% massa). ............................... 90

Tabela 7.2: Propriedades mecânicas do aço em estudo. ........................................... 90

Tabela 7.3: Valores médios e respectivos desvios padrão do núero de ciclos até a fratura para os dois grupos de amostras, ensaiadas com cargas mínima e máxima de zero e $14 \mathrm{kN}$. 100

Tabela 7.4: Parâmetros de solda utilizados em cada uma das amostras ensaiadas...101 Tabela 7.5: Resultados do ensaio utilizando o equipamento RSWA e respectiva imagem 2D gerada pelo equipamento 102 


\section{INTRODUÇÃO}

Este estudo surgiu da necessidade de melhor conhecer a técnica de ultrasonografia aplicada ao controle de soldagem por resistência a ponto, em especial a correlação destes ensaios com as técnicas de ensaio destrutivos conhecidas, que estarão listadas nos próximos capítulos.

Existem diversos fatores a serem considerados durante a avaliação de uma junta soldada por resistência a ponto. Considerando uma aplicação automotiva, foco deste estudo, um dos fatores mais importantes é o desempenho de um determinado ponto de solda quando submetido às condições de utilização mais freqüentes do componente ao qual o mesmo é aplicado.

Falhas em pontos de solda aplicados em componentes automotivos, especialmente aqueles localizados em regiões estruturais, ou que comprometem a segurança dos ocupantes podem ser considerados como catastróficos, uma vez que na maioria dos casos o retrabalho nestas carrocerias é extremamente difícil, sendo necessário desmontar e soldar novamente as partes afetadas, quando possível, o que afeta diretamente o usuário final, conforme podemos observar nas Figuras 1 e 2, com relatos de clientes referentes a falhas em pontos de solda em seus veículos.

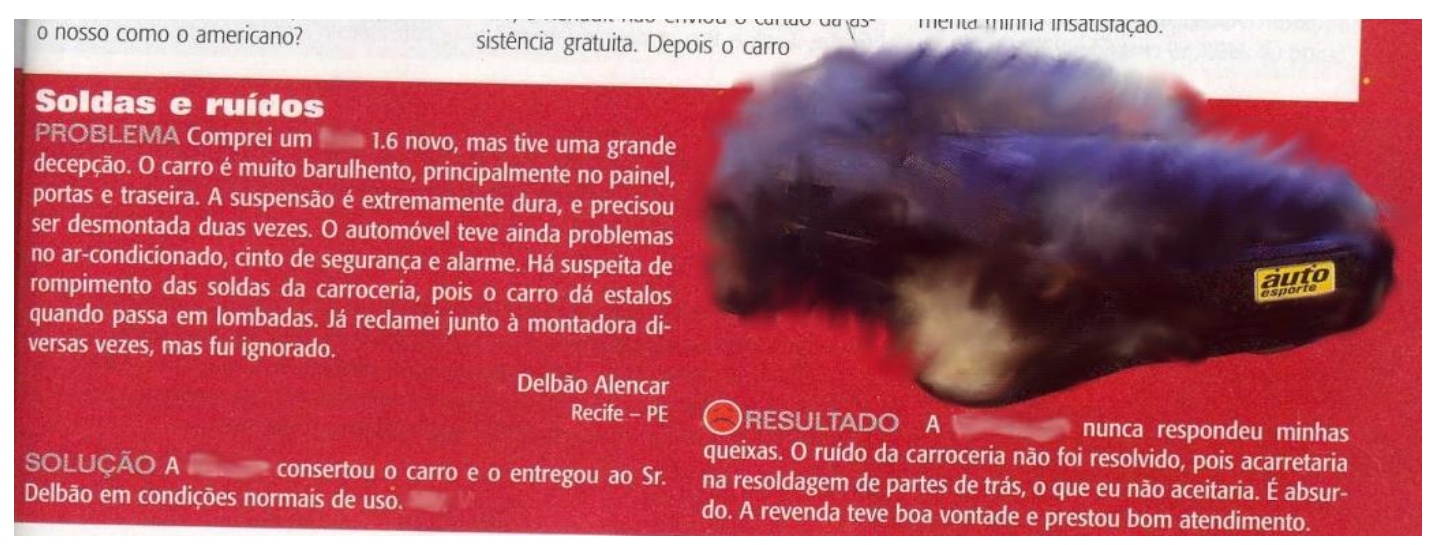

Figura 1: Reclamação de cliente registrada em revista, referente a problemas em ponto de solda (Autoesporte, 2003). 


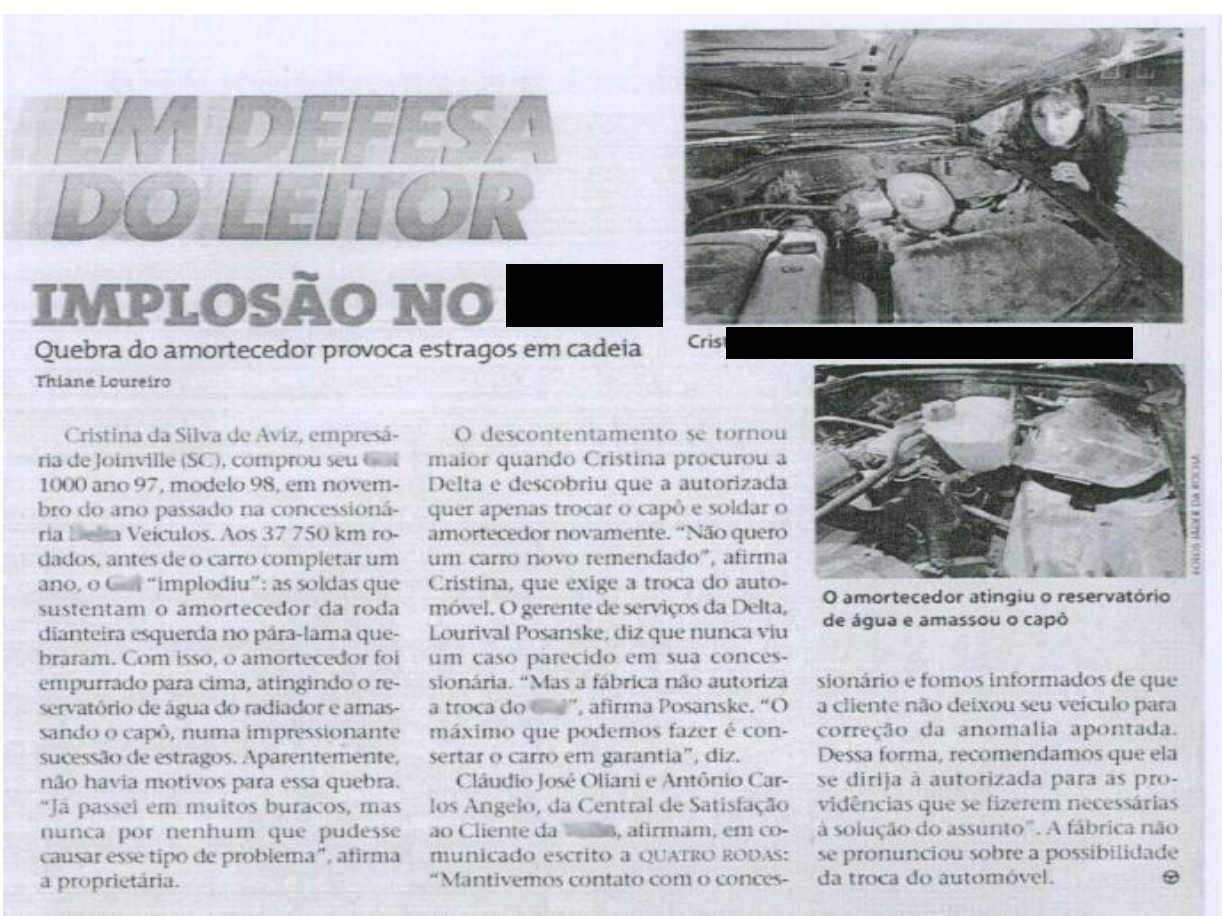

Figura 2: Reclamação de cliente registrada em revista, referente a problemas em ponto de solda (Quatro Rodas, 1998).

Sendo assim, montadoras gastam enorme energia no controle do processo de soldagem por resistência, bem como na inspeção do produto, a fim de atender os requisitos especificados nas legislações, bem como preservar a imagem da marca.

Desta forma, são fatores de controle conhecidos e bem aceitos de maneira a avaliar a qualidade de uma junta soldada por resistência a ponto:

- Diâmetro da região fundida;

- Resistência ao cisalhamento;

- Dimensão e posicionamento peça/ponto;

Conforme será mostrado no decorrer deste trabalho, técnicas de ensaios não destrutivos permitiram uma ampliação dos fatores a serem estudados, os quais de acordo com algumas literaturas também influenciam o desempenho desta junção: 
- Penetração da lentilha fundida;

- Redução da espessura nominal da junta, ocasionada pela deformação dos eletrodos de solda (indentação);

- Descontinuidades internas no ponto de solda.

Assim sendo, será demonstrada através de corpos de prova soldados com diferentes parâmetros, a correlação entre estes ensaios não destrutivos e avaliações metalográficas, descritas detalhadamente em seus respectivos capítulos.

Determinados os fatores de influência, será determinado o método de análise de dados a ser utilizado que melhor satisfaça as necessidades do projeto.

De forma resumida, este trabalho apresenta, no Capítulo 2, visão geral do processo de soldagem, suas variações e definições físicas de funcionamento. $\mathrm{O}$ Capítulo 3 é dedicado aos principais defeitos encontrados neste processo e seus causadores. No Capítulo 4, são demonstrados os ensaios destrutivos mais utilizados para a inspeção destes pontos de solda, além do ensaio metalográfico e os principais parâmetros analisados. A técnica de ultra-som e seus fundamentos são mostrados no Capítulo 5, enquanto que no Capítulo 6 é demonstrada a aplicação do ultra-som ao ensaio de solda por resistência a ponto. No Capítulo 7 executa-se a comparação dos resultados obtidos no ensaio de ultra-som com os ensaios metalográficos dos corpos de prova, além das conclusões observadas no Capítulo 8 e as oportunidades de estudos adicionais e trabalhos futuros no Capítulo 9 . 


\section{A SOLDAGEM POR RESISTÊNCIA}

\subsection{Definição de soldagem por resistência}

A soldagem por resistência é um processo de pressão, produzido a partir da superfície de contato entre duas peças distintas, por meio do calor gerado por efeito Joule durante a circulação da corrente elétrica na resistência de junção (KEARNS, 1984). As principais características desse processo são a alta velocidade de execução, onde em média são necessários menos de um segundo para a execução de um ponto, além da flexibilidade e elevada capacidade de automação deste processo.

As chapas a serem soldadas são pressionadas entre dois eletrodos não consumíveis, cuja área de contato possui perfil adequado para garantir a pressão necessária, o perfeito alinhamento e a condução sem perdas excessivas da corrente elétrica.

A passagem da corrente elétrica elevada provoca o intenso aquecimento na área de contato das peças, devido à alta resistência nesta região, pois, pela lei de Joule, tem-se que:

$$
\mathrm{Q}=\mathrm{R} \times \mathrm{I}^{2} \times \mathrm{T}_{[1]}
$$

Onde: $\mathrm{Q}=$ Energia, $\mathrm{R}=$ Resistência elétrica, $\mathrm{I}=$ Intensidade de corrente elétrica, $\mathrm{T}=$ Tempo de solda 


\subsection{Resistências elétricas}

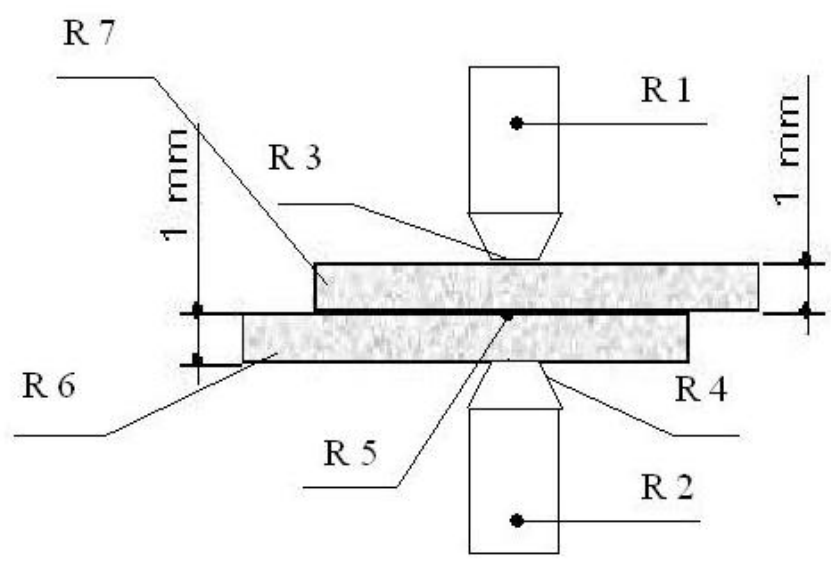

Figura 3: Resistências Elétricas

Observando a Figura 3, temos:

R1 e R2: Resistência elétrica dos próprios eletrodos

R3 e R4: Resistência elétrica que se forma no contato peça -eletrodo

R5: Resistência elétrica que se forma no contato entre as chapas

R6 e R7: Resistência elétrica das próprias chapas (peças).

O valor de R5 deve ser o maior de todos, portanto é nesta região que haverá maior geração de calor por efeito Joule e conseqüentemente a fusão e formação da lentilha de solda. O valor de R3 e R4 deve ser o mais baixo possível e é altamente influenciado quando há impurezas nestas superfícies de contato eletrodo-peça, provocando o superaquecimento nesta região gerando projeção de material, fusão do eletrodo e conseqüente adição do seu material base na superfície do ponto de solda, podendo provocar fragilizações e trincas. As referidas incrustações provocam ainda a aderência do eletrodo à chapa, além do seu amolecimento e desgaste, conforme demonstrado será no Capítulo 3. 
Durante o estágio de aquecimento as áreas de contato controlam diretamente a passagem de corrente na junta (ROGEON, 2007). Aumentando a densidade de corrente nas variadas resistências, aumenta a energia térmica na junta. Defeitos superficiais (rugosidade, óxidos, sujeiras, etc.) forçam a corrente elétrica a fluir por áreas microscópicas da peça. Esta restrição à passagem da corrente provoca um aumento da resistência elétrica localizada nestas regiões. Este fenômeno associado à existência da interface é definido por resistência de contato.

Estudos realizados anteriormente (THIEBLEMONT apud ROGEON, 2007) concordam que a medição das resistências de contato de uma junta é extremamente complexa, uma vez que as mesmas não podem ser separadas das resistências referentes à espessura da peça, sua profundidade não é definida e os valores medidos sofrem grandes variações devido à própria forma de medição, bem como a sensibilidade a fatores externos (temperatura, pressão, poluição, etc.).

\subsection{Formação da Lentilha de Solda}

O diâmetro ou forma da lentilha feita por esse processo depende do diâmetro da superfície de contato do eletrodo (superior ou inferior), do calor desenvolvido durante o tempo de passagem da corrente elétrica e da pressão aplicada.

De acordo com a espessura das peças a serem soldadas, o diâmetro da lentilha e a pressão aplicada devem ser maiores, para se obter uma resistência mecânica proporcional à seção do corte. As ilustrações da Figura 4 mostram a sequiência de solda em uma peça. 

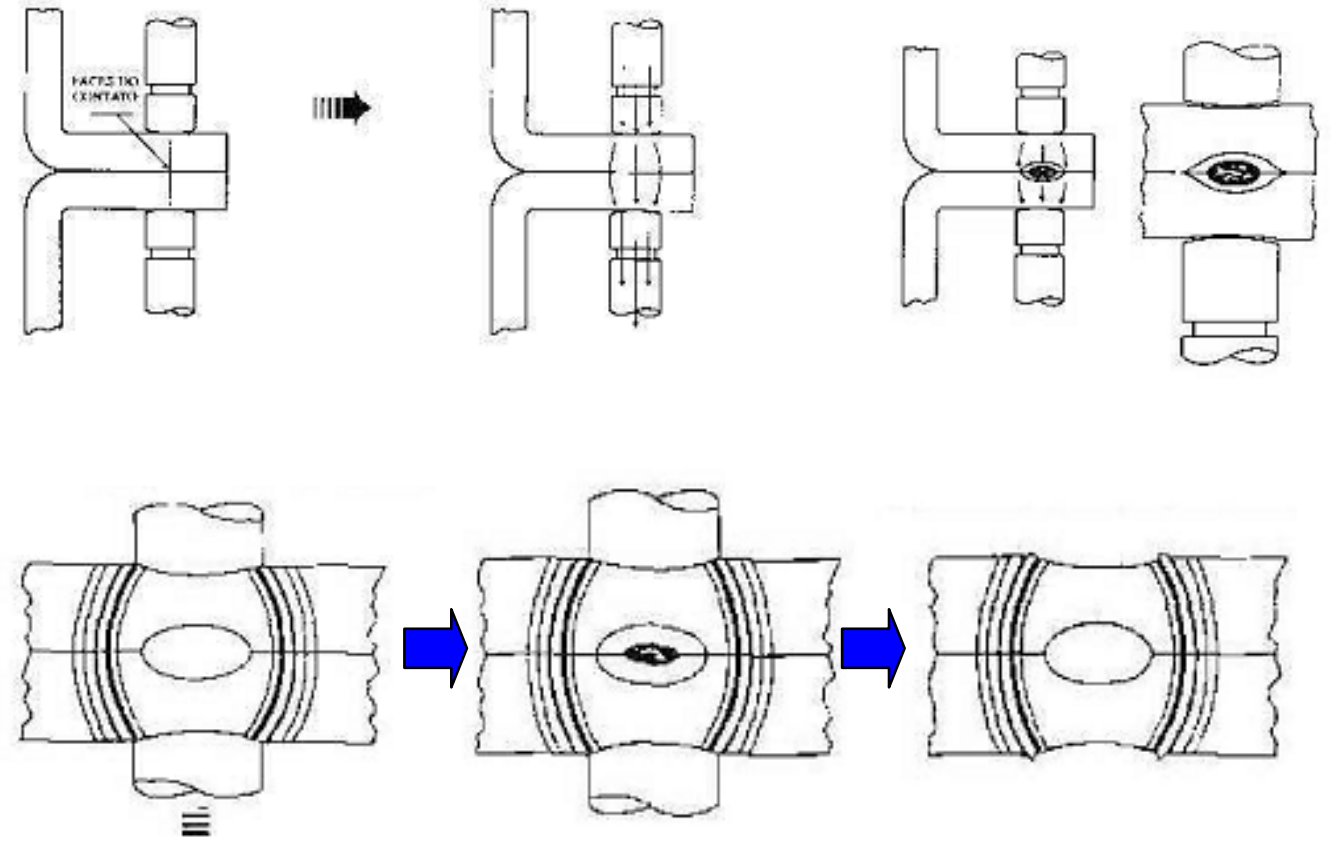

Figura 4: Esquema do processo de soldagem (MARIMAX, 2005)

\subsection{Distribuições de temperaturas e Zonas Metalúrgicas}

A geração de calor conforme descrito no item 2.2, produz o perfil de temperatura como mostra a Figura (5) onde é possível observar uma faixa de temperaturas variando de $200^{\circ} \mathrm{C}$ a $1490^{\circ}$.

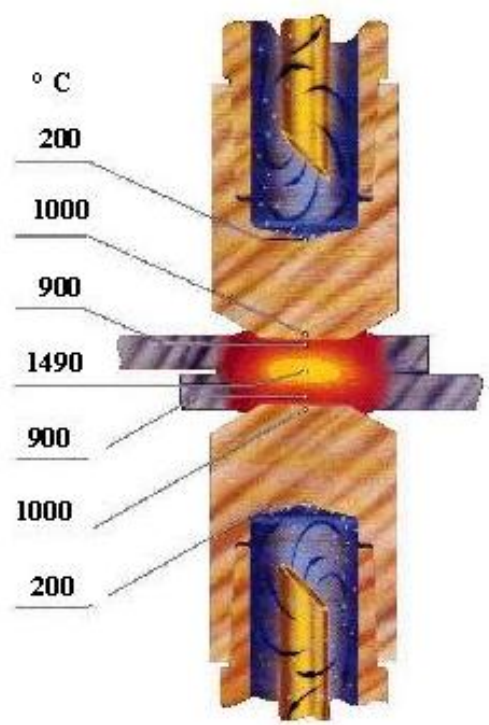

Figura 5: Distribuição de temperaturas (MEDAR, 2004) 
A intensidade da corrente gera calor nas superfícies de contato das chapas, devido ao aumento da resistência à passagem da corrente, oferecidas pelas superfícies irregulares e oxidadas. O calor desenvolvido é retido nesse ponto e são atingidas temperaturas elevadas, causando a fusão das chapas a serem soldadas. Pode ser observado que a temperatura máxima e o calor ocorrem nas interfaces das chapas e que diminuem rapidamente para os materiais e as interfaces dos eletrodos, onde há um ligeiro aumento de temperatura.

Com isso será formada a lentilha de solda, definida pela região onde houve fusão entre as chapas.

A Figuras 6 e 7 mostram exemplos de pontos de solda, considerando uma condição de resfriamento ideal (ZHANG, 2005), e observado através de técnicas metalográficas (STOCCO, 2003), conforme será mostrado em detalhes no capítulo 4.

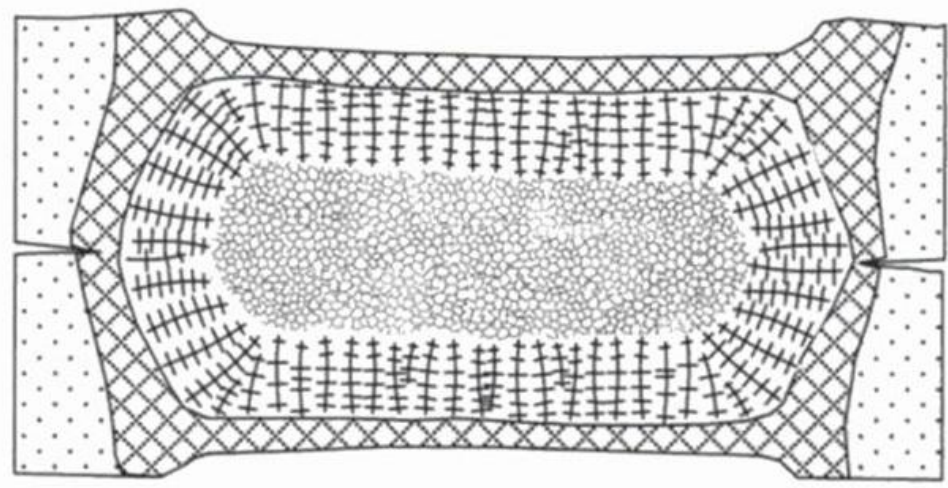

Figura 6: Estrutura esquemática de uma lentilha de solda solidificada considerando resfriamento ideal e uniforme (ZHANG, 2005)

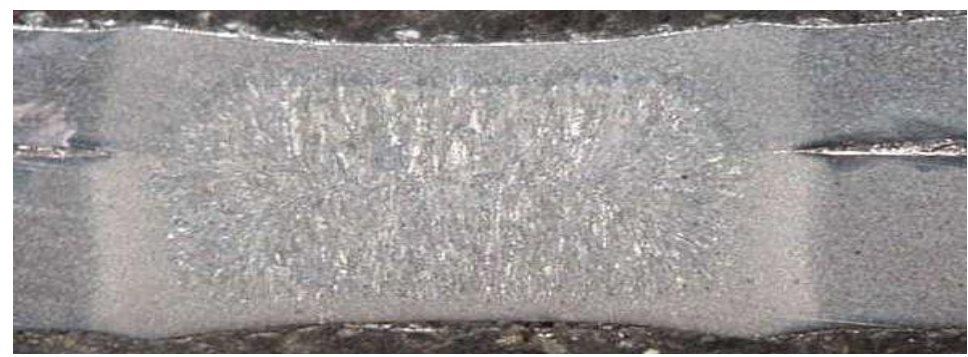

Figura 7: Seção transversal de um ponto soldado mostrando região fundida e zonas termicamente afetadas, ataque nital 2\%, 50X (STOCCO, 2003) 
Conforme mostra a Figura 7, a estrutura metalúrgica básica de um ponto de solda em ordem (STOCCO 2003) consiste em um núcleo de estrutura baínitica, com grãos colunares direcionados preferencialmente no sentido vertical, contornado por uma região termicamente alterada, diminuindo progressivamente para uma estrutura praticamente inalterada junto às superfícies das chapas.

\subsection{Definições dos parâmetros de soldagem}

A formação ideal da lentilha de solda é gerada por uma combinação de fatores, conhecidos como parâmetros de solda. Dentre eles, a intensidade da corrente elétrica, o tempo e forma desta aplicação desta corrente, e força de fechamento dos eletrodos são notadamente os que apresentam maior divergência de resultado quando submetidos a variações.

O calor necessário para a fusão do metal é desenvolvido durante o tempo de passagem da corrente elétrica, através do metal, no ponto de pressão.

A pressão a ser exercida nesse ponto dependerá do diâmetro da superfície ativa ou de contato do eletrodo, qualidade do metal e espessura das peças a serem soldadas. O diâmetro da face do eletrodo, isto é, a superfície ativa ou de contato deve-se manter o mais constante possível, pois pequenas deformações causam variações de resistência.

A intensidade da corrente gera calor nas superfícies de contato do metal, devido ao aumento da resistência à passagem da corrente, oferecidas pelas superfícies irregulares e oxidadas. O calor desenvolvido é retido nesse ponto e são atingidas temperaturas elevadas, causando a fusão do metal que estiver sendo soldado.

Pode ser observado que a temperatura máxima e o calor ocorrem nas interfaces dos metais e que diminuem rapidamente para os materiais e as interfaces dos eletrodos, onde há um ligeiro aumento de temperatura. 
Este último aumento é seguido de uma diminuição da temperatura da água no fundo do orifício de refrigeração do eletrodo. Pode ser facilmente deduzido que, se existir água insuficiente circulando, a temperatura dos eletrodos e componentes subirá.

É evidente que existem variáveis nestes pontos que produzem a quantidade de calor necessária para a fusão.

Estas variáveis podem ser assim classificadas:

- $\quad$ Irregularidades das superfícies internas e oxidações;

- $\quad$ Tipo de material a ser soldado;

- Tratamentos superficiais da chapa;

Quantidade de corrente elétrica;

Espaço de tempo em que a corrente é fornecida;

Força de fechamento entre os eletrodos.

O primeiro item é difícil de controlar e, desde que este e o segundo item não têm grande efeito no processo, podemos nos dedicar às três principais variáveis: corrente, tempo e pressão - o transformador modifica a corrente elétrica que entra no primário de alta tensão para uma alta corrente no secundário, apropriada para solda.

A capacidade do transformador fornece a quantidade total de corrente disponível nos eletrodos para produzir a quantidade de calor necessária. Uma vez que a corrente fornecida pelo transformador seja adequada, é necessário manter esta corrente e conseqüentemente a energia gerada por um tempo suficiente para que haja a formação da lentilha fundida. Este espaço de tempo (tempo de solda) é essencial para fornecer o calor suficiente para completar a fusão do material, como veremos a seguir. 
A força de fechamento dos eletrodos tem como objetivo estabilizar eventuais deformações da junta, além de controlar a resistência de contato entre as chapas e evitar a expansão demasiada do ponto após a sua solidificação.

A intensidade de corrente aplicada controla a quantidade de energia introduzida na junta, e é o fator que apresenta resultado mais acentuado e imediato. A forma de aplicação desta corrente seja crescentes, decrescentes, constantes, intermitentes, etc., tem por objetivo controlar a fusão da poça, e assim evitar projeção de material e aquecimento desnecessário da junta.

A determinação destes parâmetros depende de uma série de fatores, como materiais utilizados, potência e geometria do equipamento, eletrodos utilizados e outros.

\subsubsection{Corrente elétrica}

A intensidade de corrente elétrica na soldagem por resistência (WAINER, 1995) é determinada em função das características físicas e da espessura do material a soldar, variando para as aplicações mais usuais dentro de valores entre 5 e $30 \mathrm{kA}$.

Fatores como o mal recondicionamento dos eletrodos pode gerar teremos uma excessiva diminuição na área de contato eletrodo - peça, com forte aumento na densidade de corrente provocando superaquecimento e conseqüente prejuízo na qualidade dos pontos soldados.

Assim, para obter - se pontos de solda de boa qualidade, os eletrodos devem ser recondicionados por fresamento, buscando manter a geometria do mesmo o mais próximo possível da condição original. 


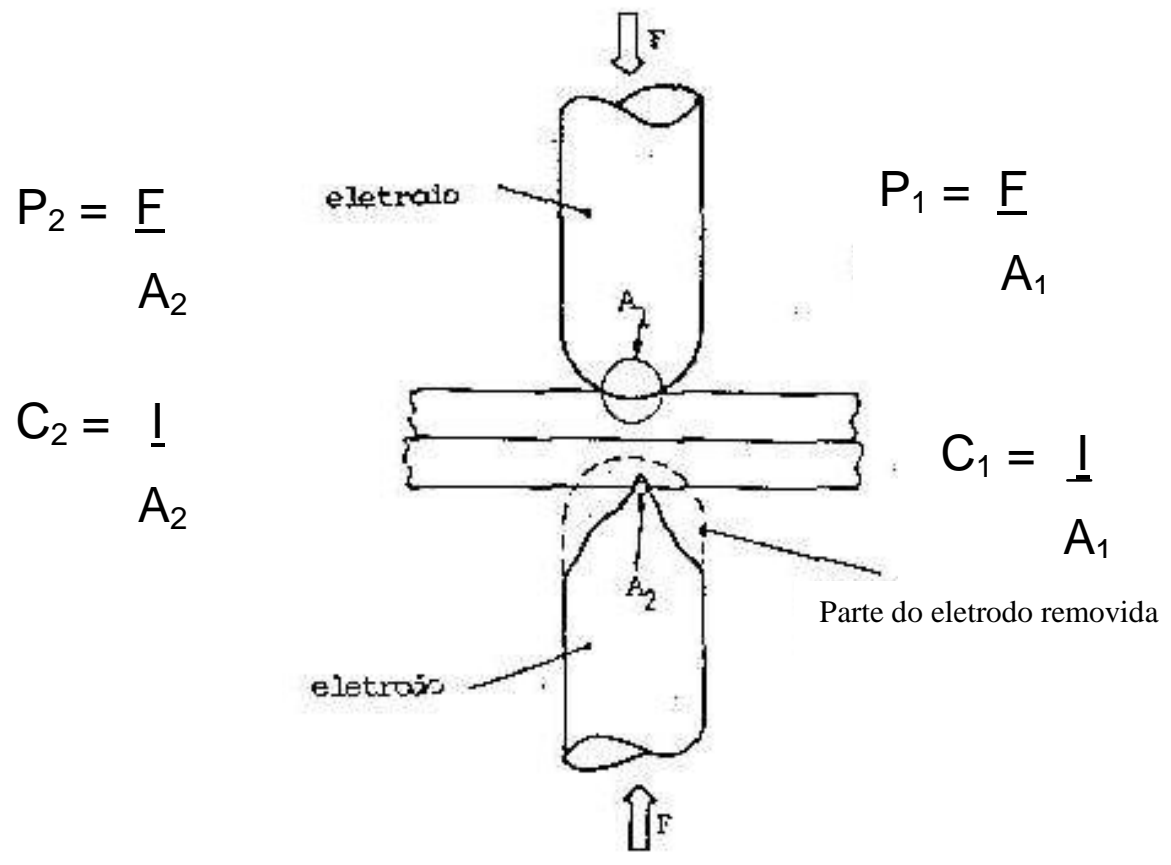

Figura 8. Perfil de recondicionamento de eletrodos (DaimlerChrysler, 2002).

A1 = área de contato do eletrodo novo ou bem recondicionado

P1 = pressão do eletrodo novo ou bem recondicionado

$\mathrm{C} 1$ = densidade de corrente do eletrodo novo ou bem recondicionado

A2 = área de contato do eletrodo mal recondicionado

P2 = pressão do eletrodo mal recondicionado

$\mathrm{C} 2$ = densidade de corrente do eletrodo mal recondicionado

$\mathrm{F}=$ Força aplicada entre os eletrodos

Como $\mathrm{A} 1>\mathrm{A} 2$, temos no eletrodo mal recondicionado um excesso de pressão e de densidade de corrente.

As peças a serem soldadas devem ser isentas de óleo ou materiais gordurosos, pois estes dificultam a passagem da corrente. A Figura 8 mostra o fluxo da corrente 
de solda em função da geometria dos eletrodos e da espessura dos materiais a serem soldados.

\subsubsection{Tempo de soldagem}

O tempo de solda (FURLANETTO, 2004) é definido como o tempo de passagem da corrente elétrica na junta a ser soldada. Usualmente, este tempo é expresso em ciclos. Assim, quando o tempo de solda for 15 ciclos, a sua duração é $1 / 4$ de segundo, pois a frequiência da rede elétrica no Brasil é de 60 Hertz. Quanto maior o tempo de solda maior serão as perdas de calor por dissipação, diminuindo o rendimento térmico da soldagem além de aumentar as distorções do componente que se está soldando. Sendo assim, o objetivo será sempre utilizar o menor tempo de soldagem possível.

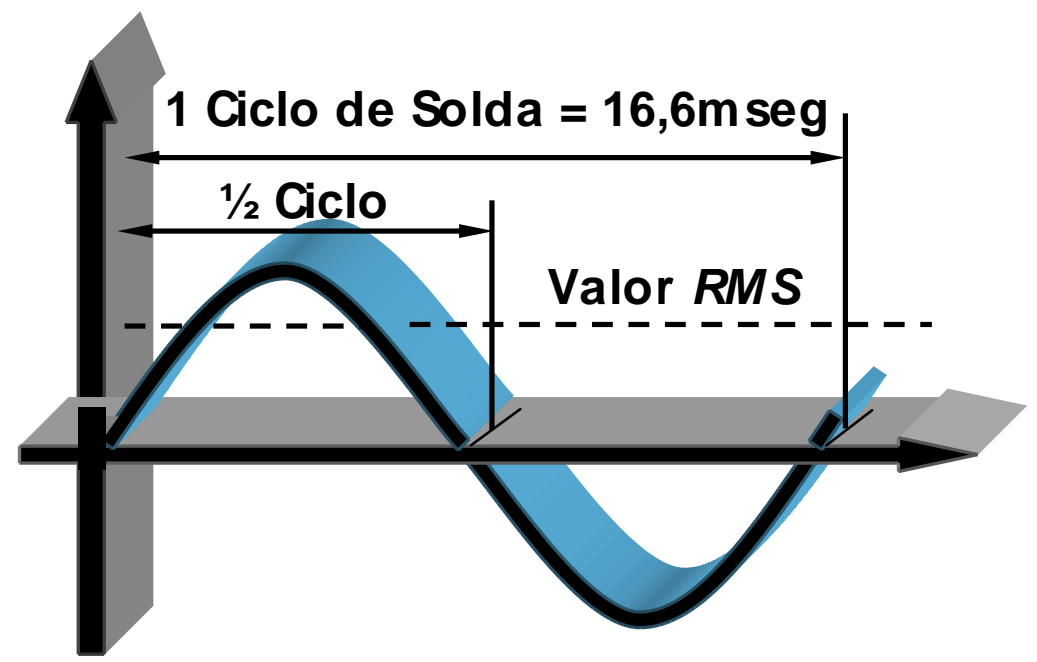

Figura 9. Senoidal representando 1 ciclo de corrente de solda (FURLANETTO, 2004)

\subsubsection{Força entre os eletrodos}

De acordo com (WAINER, 1995), a força entre os eletrodos assegura o perfeito contato entre as peças (pré - pressão) e evita a formação de trincas, devido aos esforços provocados pela contração de solidificação da lentilha de solda durante o resfriamento (pós - pressão). O valor da força deve ser bem determinado, pois estando muito abaixo do especificado produzirá projeções de material do ponto de solda que, ao contrário do que pensam muitos soldadores, é prejudicial à solda, 
tornando - a de baixa qualidade, além de aumentar o valor das resistências de contato, podendo provocar a formação de circuitos derivados.

Compensar a folga entre as chapas a soldar através da força entre os eletrodos também não é uma prática recomendada, pois atuará na solda uma força menor que aquela especificada, porque parte dela estará sendo consumida na aproximação das chapas.

A força sendo muito alta tem como inconveniente à formação de rebarbas, como mostra a Figura 10.

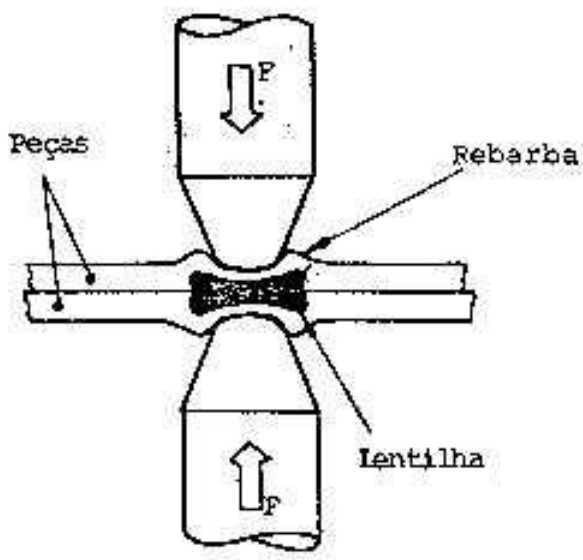

Figura 10. Formação de rebarba e deformação da lentilha, devido à excessiva força entre os eletrodos (DaimlerChrysler, 2002). 


\subsubsection{Resfriamento do ponto de solda}

O ponto de solda deve resfriar mantendo-se a força entre os eletrodos após a interrupção da corrente elétrica, denominado pós - pressão. A dissipação do calor é feita em grande parte pelo eletrodo, que é refrigerado através de um sistema de passagem de água sob pressão.

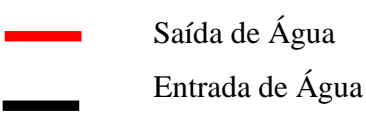

Figura 11. Sistema de Refrigeração dos eletrodos (MEDAR, 2004 - Modificado)

Os vazamentos de água nos eletrodos e tubulações devem ser corrigidos, pois provocam uma queda na pressão do sistema e a conseqüente perda do rendimento na refrigeração, provocando o desgaste prematuro dos eletrodos.

\subsubsection{Eletrodos para soldagem por resistência a ponto}

\subsubsection{1 - Forma dos eletrodos:}

Os eletrodos utilizados na soldagem por resistência a ponto têm sua forma definida em função da geometria da peça a soldar, assim, temos eletrodos retos, curvos, com ponta cônica, arredondada, achatada e excêntrica. 


\subsubsection{2 - Propriedades das ligas utilizadas:}

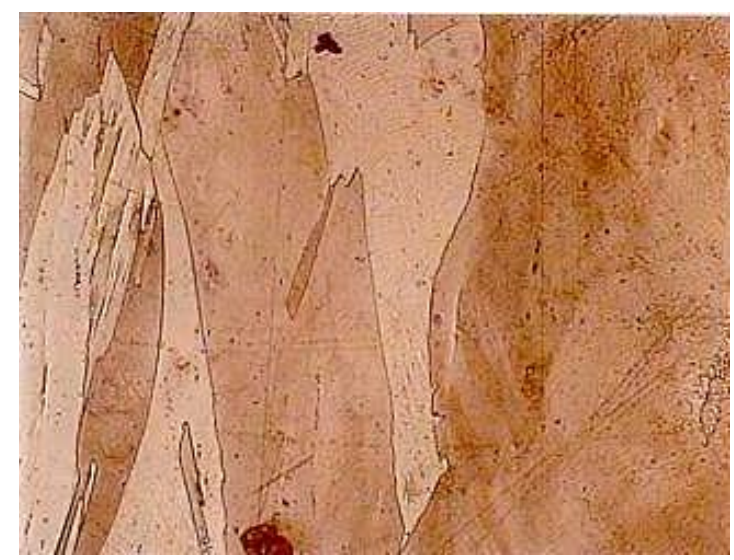

Figura 12: Seção transversal de eletrodo de liga $\mathrm{Cu}-\mathrm{Cr}$, com 200X de aumento (DaimlerChrysler,2002)

Os eletrodos devem ter elevada dureza, resistência ao amolecimento e ao desgaste em temperaturas elevadas, além de não formar liga de baixo ponto de fusão com o material a ser soldado, e ter boa condutibilidade elétrica.

Para atender tais requisitos são usualmente utilizadas ligas de Cobre (KOLOSOWSKI, 2003) endurecidas por tratamento térmico de precipitação.

Para as aplicações usuais utiliza-se a liga $\mathrm{Cu} / \mathrm{Cr}$ A2/1 (DIN 4475). A tabela a seguir indica as principais ligas utilizadas.

Tabela 2.1: Ligas de Cobre utilizadas para eletrodos na soldagem por pontos.

\begin{tabular}{|c|c|c|c|}
\hline Material a ser soldado & Processo & Peça da Máquina & Material \\
\hline \multirow{3}{*}{ 20 } & Por ponto & $\begin{array}{c}\text { Eletrodo } \\
\text { Porta-eletrodo }\end{array}$ & $\mathrm{CuCr}-\mathrm{CuCrZr}-\mathrm{CuNi}$ \\
\hline & Por costura & $\begin{array}{c}\text { Disco } \\
\text { Componentes Outros }\end{array}$ & $\begin{array}{c}\mathrm{CuCr}-\mathrm{CuCrNi}- \\
\mathrm{CuAg}-\mathrm{CuCr}- \\
\mathrm{CuCoBe}(\mathrm{x})-\mathrm{CuNi}\end{array}$ \\
\hline & Projeção & Dispositivo Inserto & $\begin{array}{c}\mathrm{CuNi}-\mathrm{CuW}-\mathrm{CuNi}- \\
\mathrm{CuCoBe}\end{array}$ \\
\hline \multirow{3}{*}{$\begin{array}{l}\text { Aço Inox } \\
\text { Ligas } \mathrm{NiCr}\end{array}$} & Por ponto & $\begin{array}{c}\text { Eletrodo } \\
\text { Porta-eletrodo }\end{array}$ & $\mathrm{CuCoBe}-\mathrm{CuNi}$ \\
\hline & Por costura & Disco & $\mathrm{CuCoBe}$ \\
\hline & Projeção & Dispositivo & $\mathrm{CuCoBe}$ \\
\hline \multirow[t]{2}{*}{ Alumínio e Ligas Leves } & Por ponto & $\begin{array}{c}\text { Eletrodo } \\
\text { Porta-eletrodo }\end{array}$ & CuTeNi \\
\hline & Por costura & Disco & CuTeNi \\
\hline Cobre & Por pontos & Eletrodos & Insertos de $\mathrm{Cu}-\mathrm{W}$ \\
\hline Bronze & Por pontos & Eletrodos & $\mathrm{CuCd} \mathrm{CuAg} / \mathrm{CuCrZr}$ \\
\hline Latão & Por pontos & Eletrodos & $\mathrm{CuCd}-\mathrm{CuAg}$ \\
\hline
\end{tabular}




\subsubsection{3 - Influência do estado dos eletrodos:}

O desgaste dos eletrodos é resultado do uso excessivo ou irregular, que tem como consequiência o aumento da área da região de contato com a peça. Assim teremos uma diminuição da densidade de corrente obtendo-se pontos de solda de baixa qualidade.

O aumento da área de contato também tem como efeito o aumento da resistência R3 e R4, provocando aquecimento e aderência do eletrodo nas chapas.

Outro inconveniente dos eletrodos gastos é a presença de uma incrustação escura, proveniente da queima de óleos e gorduras, que provoca a diminuição da condutibilidade elétrica do eletrodo. O eletrodo limpo possui uma condutibilidade de no mínimo $75 \%$ IACS e com a referida incrustação este valor cai para valores muito pequenos, isolando a passagem da corrente elétrica.

Por outro lado, quando os eletrodos são apresentam recondicionamento deficiente podem-se produzir pontos furados ou queimados, conforme mostrado nos capítulos posteriores.

Para evitar todos esses inconvenientes, os eletrodos deverão ser periodicamente recondicionados com os equipamentos manuais, ou as fresadoras automáticas dos robôs adequadas a esta finalidade. 


\section{PRINCIPAIS DEFEITOS ENCONTRADOS NA SOLDAGEM POR RESISTÊNCIA A PONTO}

Serão listadas a seguir as principais características de falha de uma junta soldada por resistência a ponto e sua influência no comportamento mecânico e na vida útil dos componentes por eles unidos.

\subsection{Ponto solto (Sem fusão, Solda fria)}

Devido a problemas que podem ser originados dentre outros pela força excessiva de contato dos eletrodos na junta, o tempo ou a intensidade de corrente de solda insuficiente, ou até o eletrodo com a área de contato muito larga. Sua principal característica é a total ausência de uma lentilha de solda fundida. Em alguns casos, o aquecimento gerado na junta é suficiente para produzir a deformação característica de um ponto de solda na superfície da junta, podendo gerar avaliações equivocadas, em especial no caso de análises apenas visuais. Esta falha pode ser detectada sob qualquer método de inspeção conhecido com relativa facilidade.

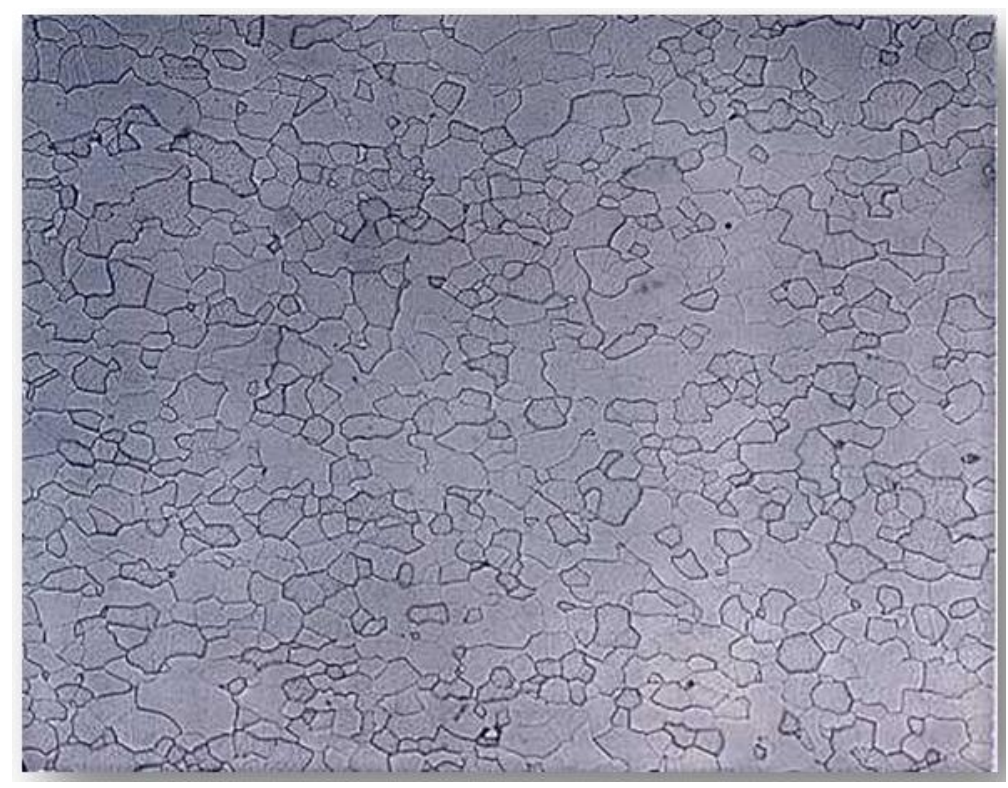

Figura 13: Microestrutura do material base da chapa a ser soldada, ataque nital $2 \%$, $100 \mathrm{X}$ 


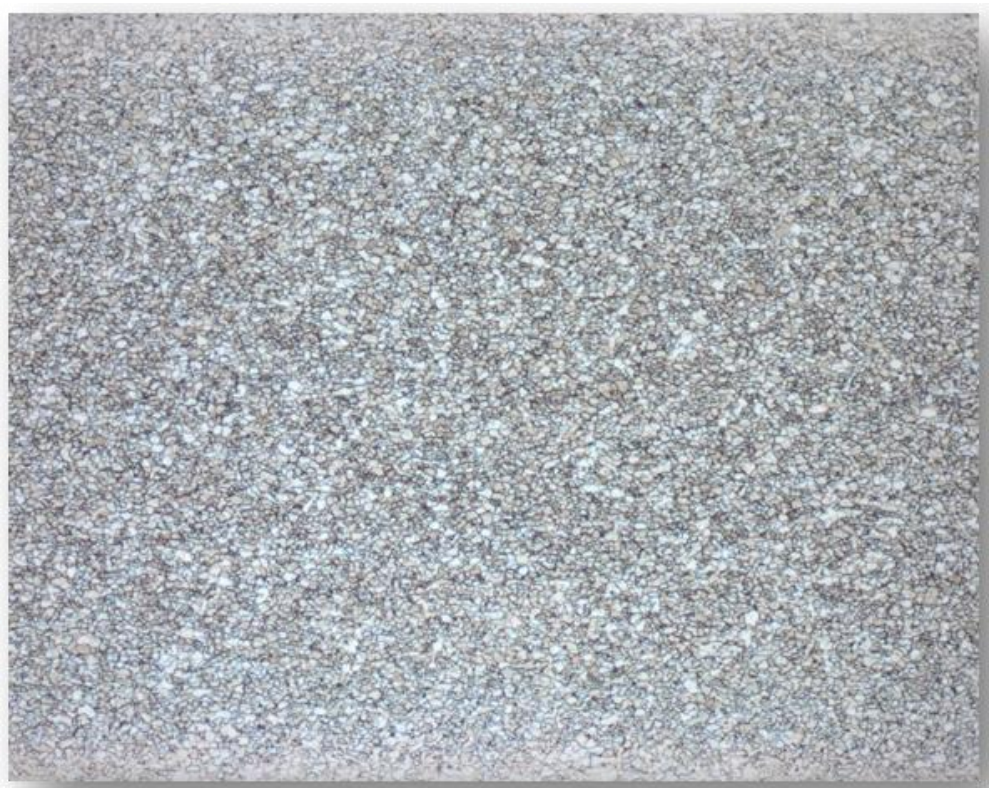

Figura 14: Microestrutura da região soldada após aquecimento, mostrando alteração térmica, porém sem a formação de lentilha soldada, ataque nital 2\%, $100 \mathrm{X}$

\subsection{Ponto colado}

É caracterizado por uma má formação da lentilha de solda, na maioria dos casos em decorrência de um aquecimento insuficiente da região a ser soldada, conforme ilustrado na imagem abaixo.

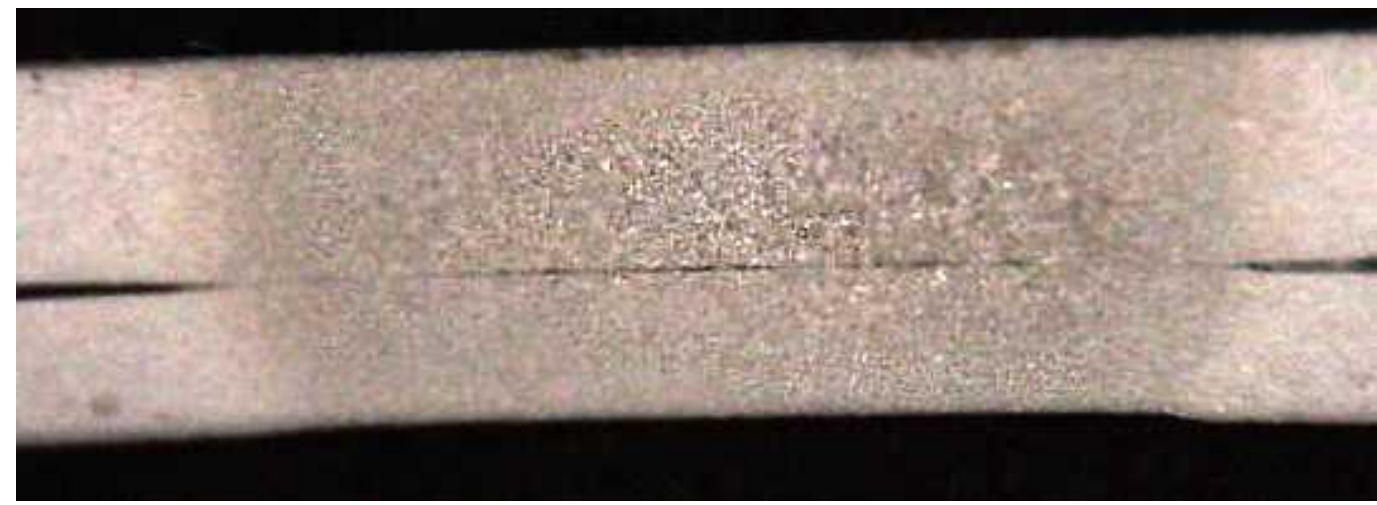

Figura 15: Seção transversal mostrando ponto de solda colado, ataque nital 2\%, 40X (DaimlerChrysler,2002) 
As causas mais prováveis para a ocorrência deste defeito são a força de fechamento excessiva do eletrodo, um tempo insuficiente de aplicação da corrente de solda (ou a sua falta), e os eletrodos com contato muito largo.

A dificuldade de detecção deste defeito é maior que a da solda fria, pois já existem pontos com início de fusão, o que pode gerar interpretações erradas, principalmente nos ensaios não destrutivos, conforme detalhado nos capítulos a seguir.

\subsection{Lentilha pequena}

Neste tipo de falha, a principal diferença está no tamanho da lentilha formada, quando comparados a normas específicas. Esta medida pode ser aferida de várias formas, tanto através de meios destrutivos como o ensaio de destacamento e a metalografia, bem como de maneira não destrutiva (indiretamente pelo A-scan e diretamente pelo B-scan).

As características da falha, bem como os efeitos causadores das mesmas são os mesmos observados nos itens 3.1 e 3.2 , e neste caso a detecção deste tipo de defeito pode ser detectada pelos métodos de inspeção destrutivos e não destrutivos.

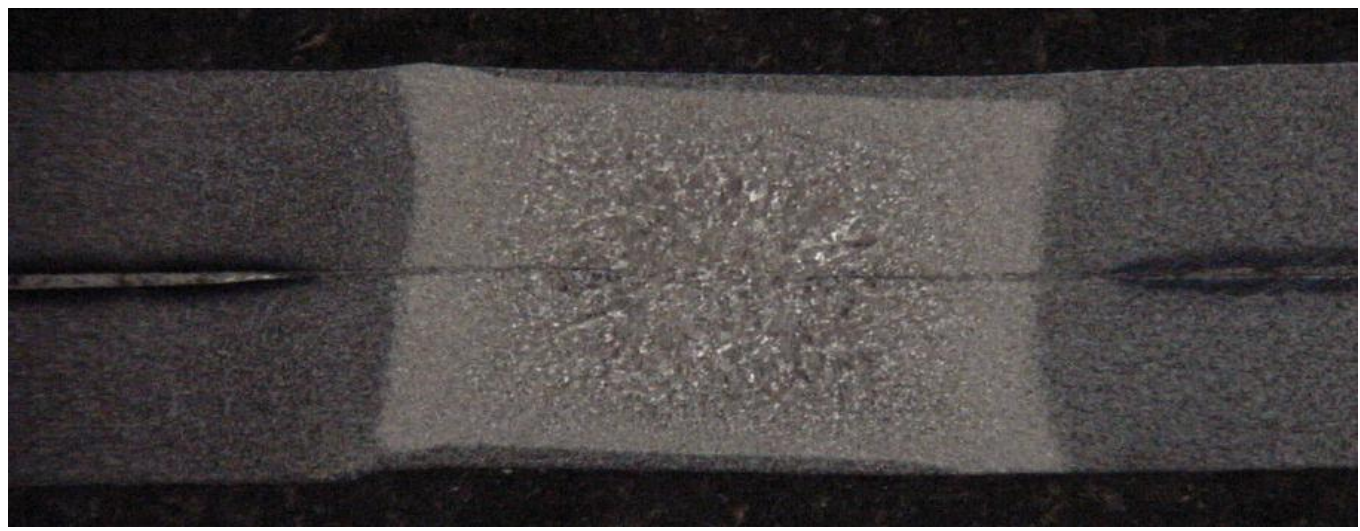

Figura 16: Seção transversal mostrando ponto com diâmetro abaixo do especificado, ataque nital 2\%, 40X (STOCCO, 2003). 


\subsection{Descontinuidade interna (Falha no ponto)}

É caracterizado pela presença de descontinuidades internas na região fundida do ponto, que podem ser originados por diversos fatores, como força ou tempo insuficiente de contato dos eletrodos, a excessiva corrente ou tempo de sua aplicação. Outro fator a ser observado e a presença de impurezas nas superfícies das chapas, como óleos e graxas, que vaporizam durante o processo de aquecimento, e devido a um dos fatores citados acima podem ficam aprisionados no centro do ponto durante a solidificação, conforme mostra a Figura 17.

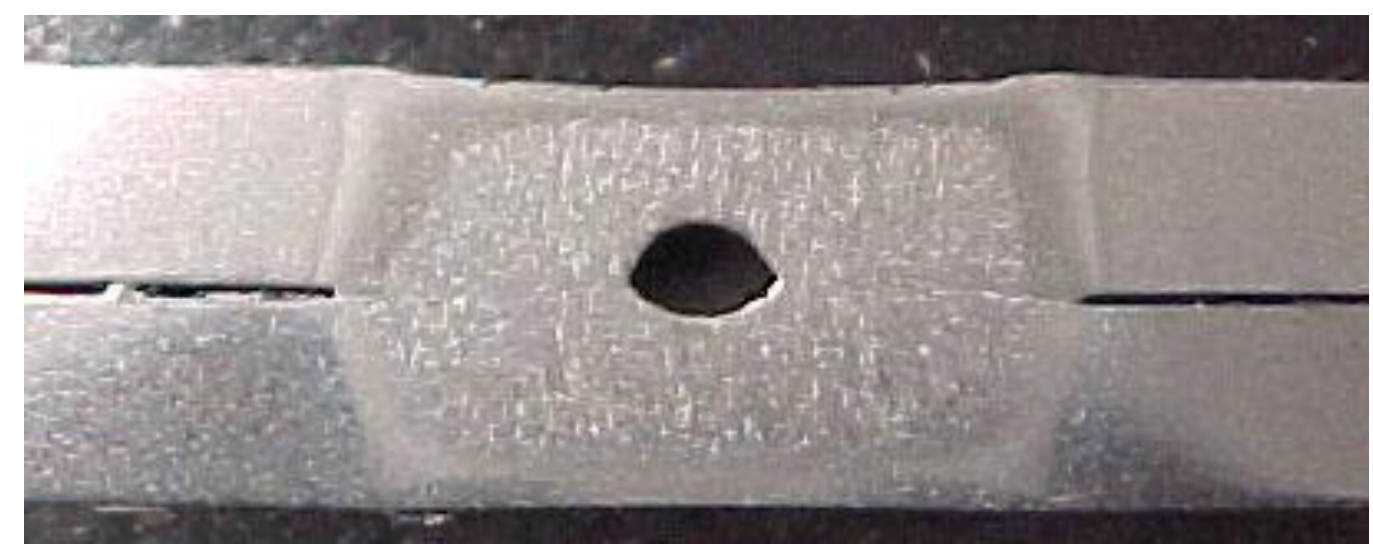

Figura 17: Seção transversal mostrando ponto de solda com descontinuidade interna, ataque nital 2\%, 40X (DaimlerChrysler,2002).

Este tipo de defeito, ao contrário dos anteriores, não pode ser detectado através do ensaio de destacamento, conforme detalhado nos capítulos a seguir, sendo a forma de detecção mais indicada os ensaios não destrutivos.

\subsection{Excessiva indentação (Ponto queimado)}

Ocorre quando a resistência compressiva do material em contato com o eletrodo diminui à medida que a fusão avança, permitindo, deste modo, que a face do eletrodo se movimente para dentro da superfície da peça de trabalho (VARGAS, 2006). Esta indentação pode ser grande quando um eletrodo com uma área superficial pequena for empregado com pressão e densidade de corrente 
excessivamente altas. Além de prejudicar o aspecto da superfície da peça de trabalho, a indentação excessiva pode diminuir a resistência mecânica da solda.

(VARGAS apud WU, 1968) mostra no seu trabalho uma relação linear entre a corrente de soldagem e a indentação do eletrodo. A indentação varia com o material a soldar e a dureza da solda se incrementa com a indentação, em um nível aceitável, até a expulsão do material fundido acontecer.

Esta indentação está mostrada na imagem a seguir de maneira exagerada para ilustrar esta condição.

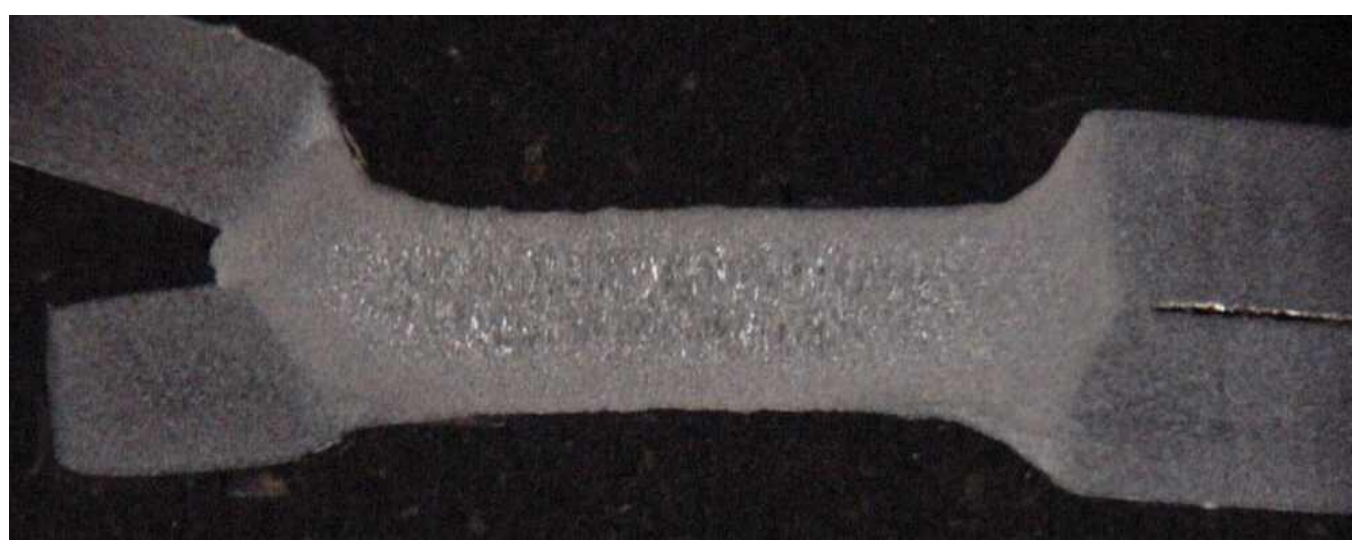

Figura 18: Seção transversal mostrando ponto de solda com indentação excessiva, ataque nital 2\%, 40X (STOCCO, 2003).

O principal efeito relacionado a estas indentações é que estas reduzem localmente a espessura da junta soldada e pode levar a concentração de ten são nestas juntas, o que pode reduzir a vida em fadiga destas uniões. Outros defeitos relacionados são o surgimento de micro trincas na superfície das chapas, em decorrência do esforço mecânico e do aquecimento excessivo, como mostram as Figuras 19, 20 e 21. 


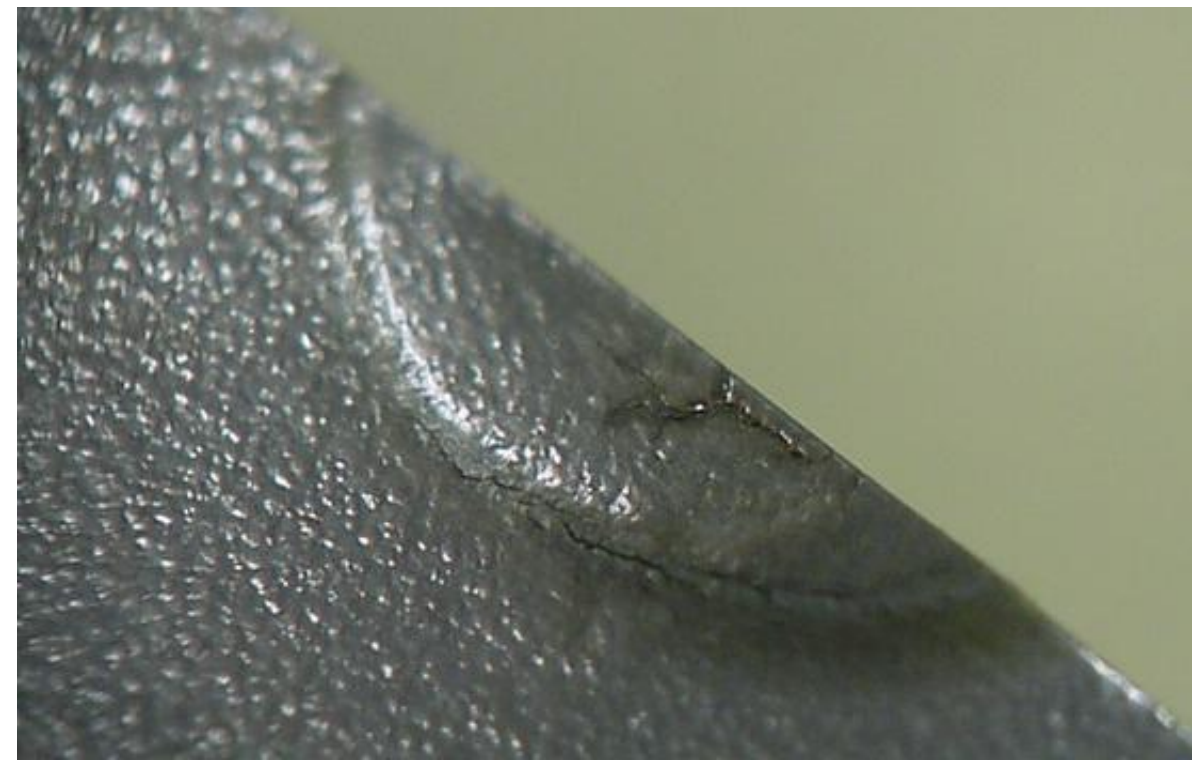

Figura 19: Detalhe da superfície do ponto de solda, apresentando trincas superficiais. (STOCCO,2003).

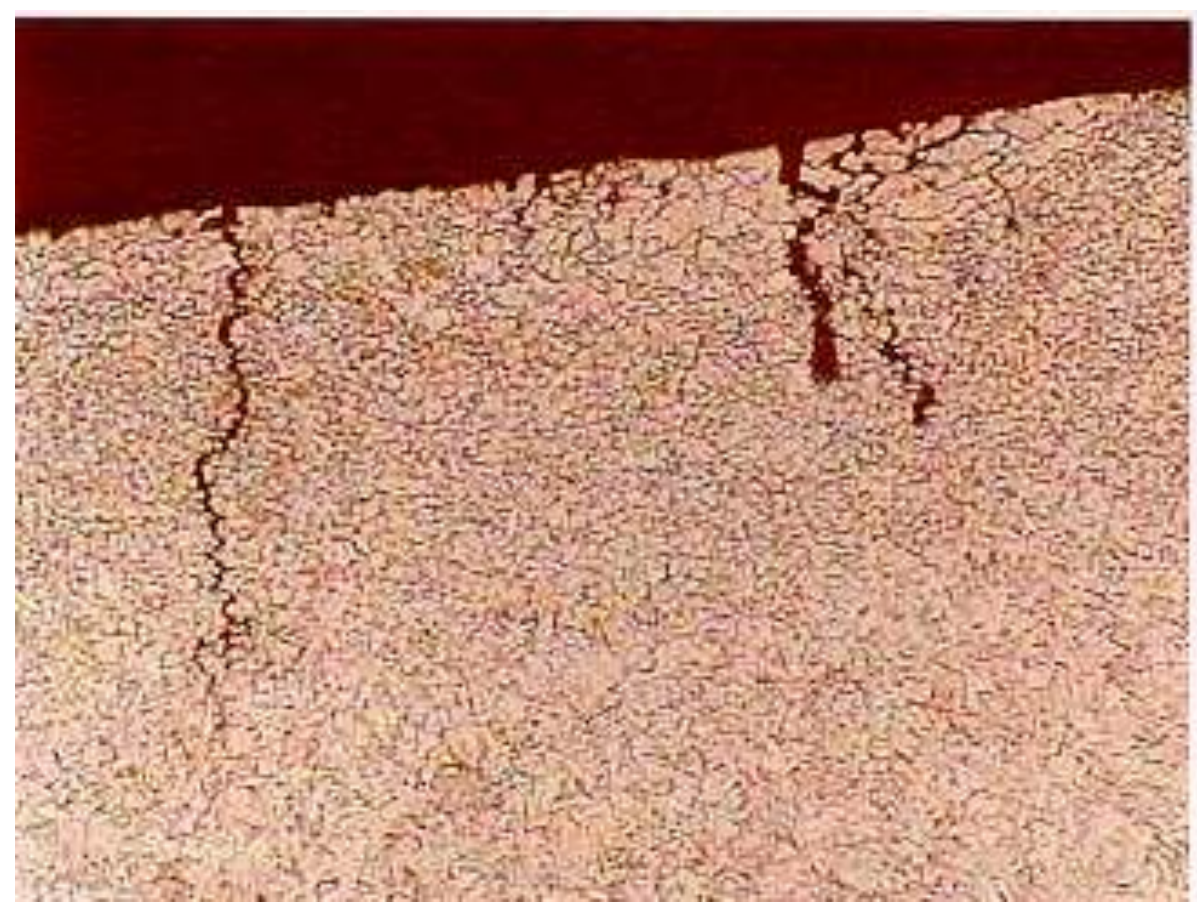

Figura 20: Seção transversal mostrando micro trincas na superfície do ponto de solda, ataque nital 2\%, 200X (STOCCO, 2003). 


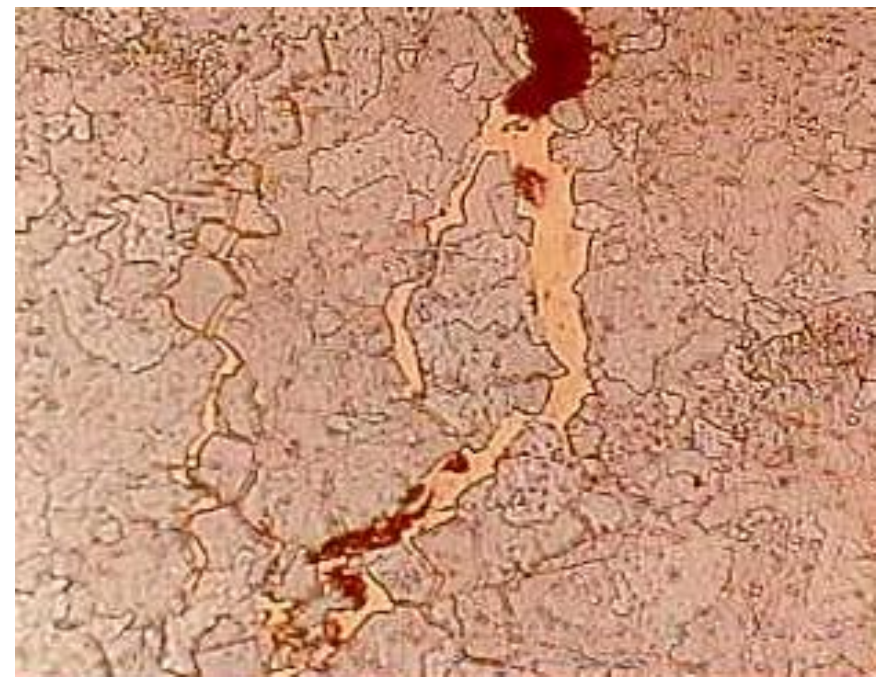

Figura 21: Seção transversal mostrando micro trinca na superfície do ponto de solda com incrustação de material base do eletrodo utilizado para a soldagem, ataque nital 2\%, 500X (STOCCO, 2003).

De maneira diferente das características de falhas anteriormente apresentadas, este tipo de defeito não é facilmente detectado através dos métodos destrutivos convencionais, pois os mesmos somente aferem o tamanho da região fundida. Assim sendo, o ensaio por ultra-som pode ser considerado o método mais indicado para detecção e controle deste tipo de defeito, conforme descrito com maiores detalhes no Capítulo 7. 


\section{ENSAIOS DESTRUTIVOS APLICADOS EM SOLDAGEM POR RESISTÊNCIA A PONTO}

Nestes ensaios a qualidade da solda é determinada pelas informações obtidas sobre um grupo de amostras aleatórias na quais são realizados os testes necessários de resistência do ponto.

\subsection{Ensaio de destacamento por martelo e talhadeira (peel test)}

GM, (2002) define o ensaio de destacamento, ou peel test, de forma resumida como a simples fratura ao redor do ponto de solda formado, e sua posterior medição através de um paquímetro, buscando obter a média do diâmetro remanescente na chapa fraturada. Ainda pode ser considerado como o teste mecânico mais comumente usado em soldas a ponto, utilizado para determinar um parâmetro quantitativo para a medição de pontos de solda. Existem várias razões para o amplo uso de teste como a facilidade de execução, o baixo custo, e a utilização em chão de fábrica. É o ensaio mais simples que pode ser realizado no ambiente fabril, e sua avaliação é extremamente subjetiva, pois não são levados em conta fatores como força requerida para o cisalhamento, além de deformações provocadas pelo método de destacamento.

Neste teste, após os corpos de prova terem sido soldados, eles são levados a um dispositivo de fixação e com auxílio de uma ferramenta apropriada, são dobrados fazendo-se o arrancamento da lentilha, como ilustrado na Figura 22(a). Em seguida mede-se com um paquímetro, o diâmetro do botão de solda em duas direções perpendiculares $(b, c)$. A qualidade da solda é avaliada pelo diâmetro da lentilha de solda que ficará aderido a uma das partes após separação (GM, 2006). 


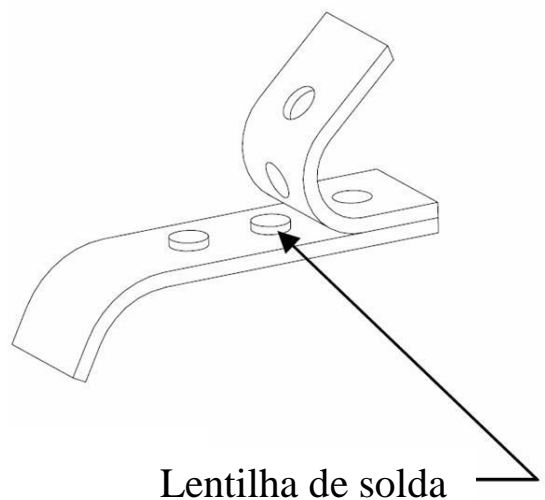

(a)

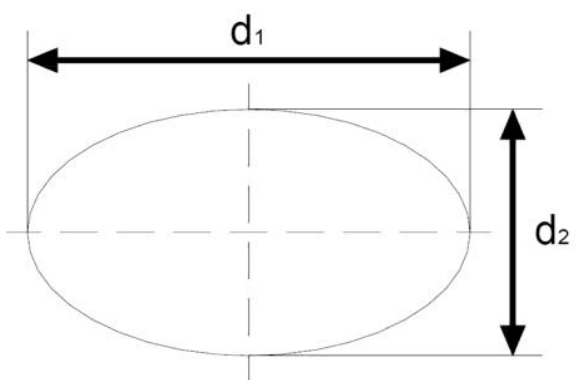

Dimensões da lentilha de solda

(b)

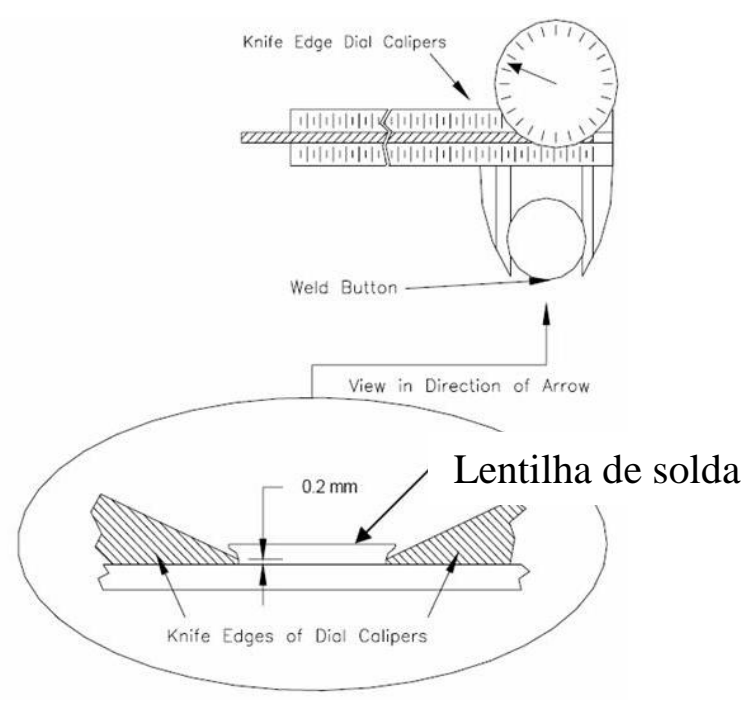

(c)

Figura 22: (a) Ilustração do ensaio de destacamento (peel test). (b) medições a serem efetuadas no caso de lentilha assimétrica. (c) localização e forma de medição (GM, 2006). 
Vale ressaltar que no caso de lentilhas assimétricas, ou aquelas que apresentam deformação excessiva causada pelo destacamento, esta medição fica bastante prejudicada, pois será necessário realizar uma série de medições em posições diferentes para que possa ser estabelecido um diâmetro de lentilha aproximado.

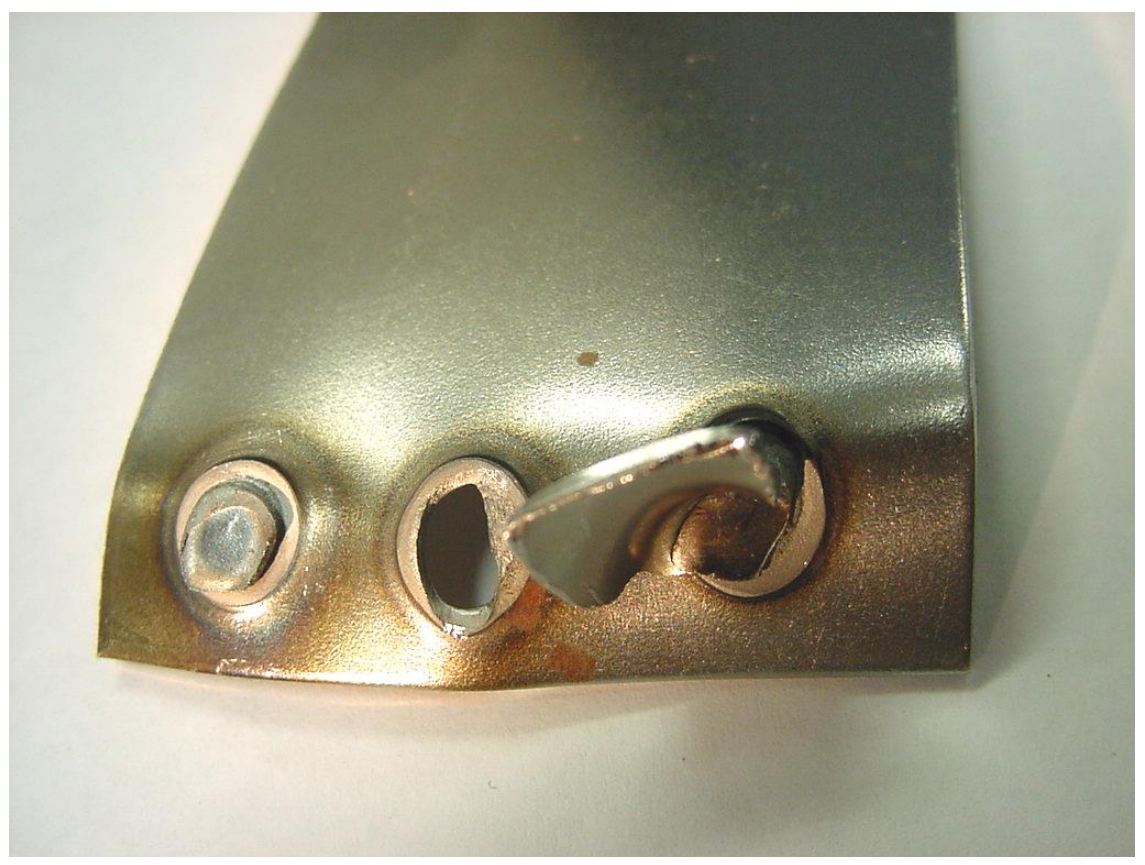

Figura 23: Corpo de prova soldado após ensaio de destacamento.

Sendo assim, este ensaio é considerado extremamente impreciso, embora fosse um dos mais utilizados no controle da solda a ponto, até o surgimento dos ensaios por ultra-som, que serão explorados nos próximos capítulos.

\subsection{Ensaios de tração}

O ensaio de tração consiste na aplicação de uma carga de tração uniaxial crescente em um corpo de prova específico até a ruptura. Mede-se a variação do comprimento (l) como função da carga (P). Trata-se de um ensaio amplamente utilizado na indústria de componentes mecânicos, devido à vantagem de fornecer dados quantitativos das características mecânicas dos materiais, onde se destacam principalmente o limite de resistência a tração $(\sigma \mathrm{u})$ e o limite de escoamento $(\sigma \mathrm{e})$. 


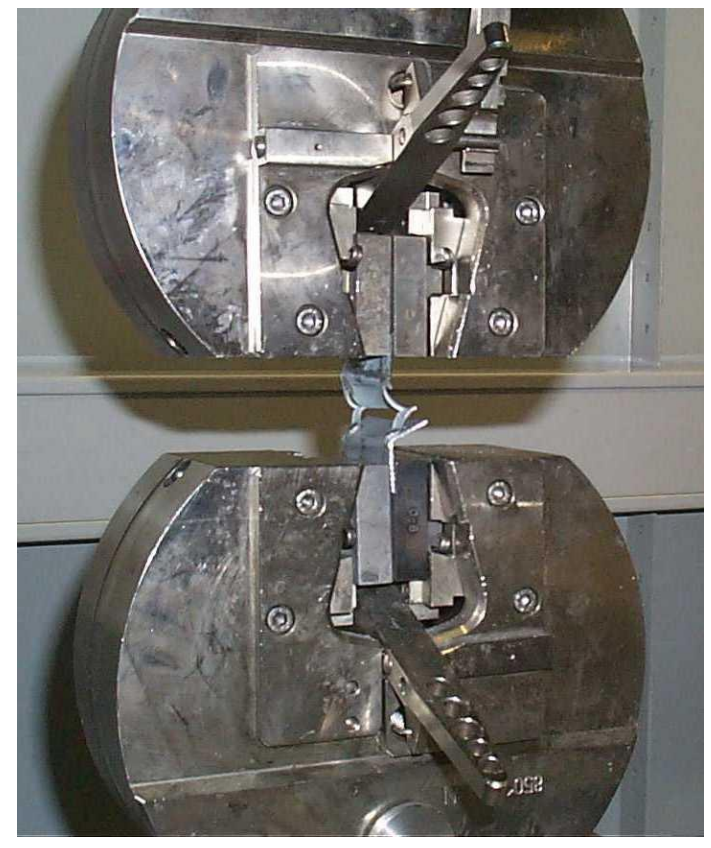

Figura 24: Ensaio de tração realizado em ponto de solda.

Para o ensaio de soldagem por resistência, apenas o valor absoluto da carga para a ruptura da amostra será considerada, e este resultado usualmente é comparado com normas existentes, como podemos observar na tabela 4.1 a seguir.

Tabela 4.1: Parâmetros de resistência da solda por resistência a ponto (GM, 2002).

\begin{tabular}{|c|c|c|c|c|c|c|c|c|}
\hline $\begin{array}{l}\text { Thickness of the } \\
\text { thinner sheet / } \\
\text { Dicke des }\end{array}$ & $\begin{array}{l}\text { Weld nugget / } \\
\text { Schweißlinsen- } \\
\text { durchmesser }\end{array}$ & $\begin{array}{r}\text { Spot wel } \\
\text { Schweilspun }\end{array}$ & $\begin{array}{l}\text { clearance at wel } \\
\text { thabstand bei Sch } \\
\mathrm{e}_{\min } \text { in } \mathrm{mm}\end{array}$ & $\begin{array}{l}\text { method / } \\
\text { eiliverfahren }\end{array}$ & $\begin{array}{l}\text { Edge clearance } \\
\text { (Note 1)// } \\
\text { Randabstand }\end{array}$ & $\begin{array}{l}\text { Shear strength } \\
\text { per spot weld I } \\
\text { Scherkraf pro }\end{array}$ & $\begin{array}{l}\text { Outer diameter of } \\
\text { welding cyinder } / \\
\text { Außsendurchmes- }\end{array}$ & $\begin{array}{l}\text { Electrode contac } \\
\text { pressure } \\
\text { (Note 2)/ }\end{array}$ \\
\hline $\mathrm{s}_{\min }$ in $\mathrm{mm}$ & $\mathrm{d}_{\min }$ in $\mathrm{mm}$ & $\begin{array}{c}\text { not shunted } \\
\text { (Note 3) / } \\
\text { nicht verschoben } \\
\text { (Note 3) }\end{array}$ & $\begin{array}{c}1 \times \text { shunted } \\
\text { (Note 3) / } \\
\text { 1x verschoben } \\
\text { (Note 3) }\end{array}$ & $\begin{array}{l}\text { single spot } \\
\text { (Note 4)/ } \\
\text { einzeln (Note 4) }\end{array}$ & $a_{\min }$ in $\mathrm{mm}$ & $\mathrm{F}_{\min }$ in $\mathrm{N}$ & in $\mathrm{mm}$ & in $\mathrm{N}$ \\
\hline 0.75 & 3.5 & \multirow{4}{*}{50} & \multirow{4}{*}{25} & \multirow{3}{*}{15} & 6.0 & 1900 & \multirow{4}{*}{48} & 2000 \\
\hline- & - & & & & - & - & & - \\
\hline 1.0 & 4.0 & & & & 6.5 & 2500 & & 2300 \\
\hline 1.25 & 4.5 & & & 20 & 7.5 & 3200 & & 2800 \\
\hline 1.5 & 5.0 & 56 & 28 & 26 & 8.0 & 3900 & 55 & 3200 \\
\hline 1.75 & 5.3 & \multirow{4}{*}{72} & \multirow{4}{*}{36} & \multirow{2}{*}{30} & 8.5 & 4400 & \multirow{4}{*}{70} & 4300 \\
\hline 2.0 & 5.7 & & & & 9.0 & 5100 & & 5000 \\
\hline 2.25 & 6.0 & & & \multirow{2}{*}{36} & 9.5 & 5650 & & 5900 \\
\hline 2.5 & 6.3 & & & & 10.0 & 6250 & & 6800 \\
\hline 2.75 & 6.6 & \multirow{2}{*}{92} & \multirow{2}{*}{46} & 39 & 10.5 & 6850 & \multirow{2}{*}{90} & 7500 \\
\hline 3.0 & 6.9 & & & 45 & 11.0 & 7500 & & 8000 \\
\hline
\end{tabular}


Sendo assim, este ensaio apresenta vantagens em relação ao ensaio de destacamento por martelo e talhadeira, uma vez que é possível registrar os valores de resistência dos pontos de solda ao cisalhamento. Em contrapartida, este ensaio consome tempo excessivo, a um custo considerado elevado para ser utilizado rotineiramente durante a produção seriada de um componente.

\subsection{Ensaios metalográficos ou macrográficos}

Este ensaio consiste na verificação a olho nu, ou com ampliação de até 1000 vezes um corpo de prova, caracterizado por uma seção transversal do ponto de solda, devidamente lixado e polido a níveis refinados. O ensaio de macrografia (SENAI, 1997) permite verificar a verificar a homogeneidade ou heterogeneidade do produto e constatar a existência de descontinuidades internas na região soldada.

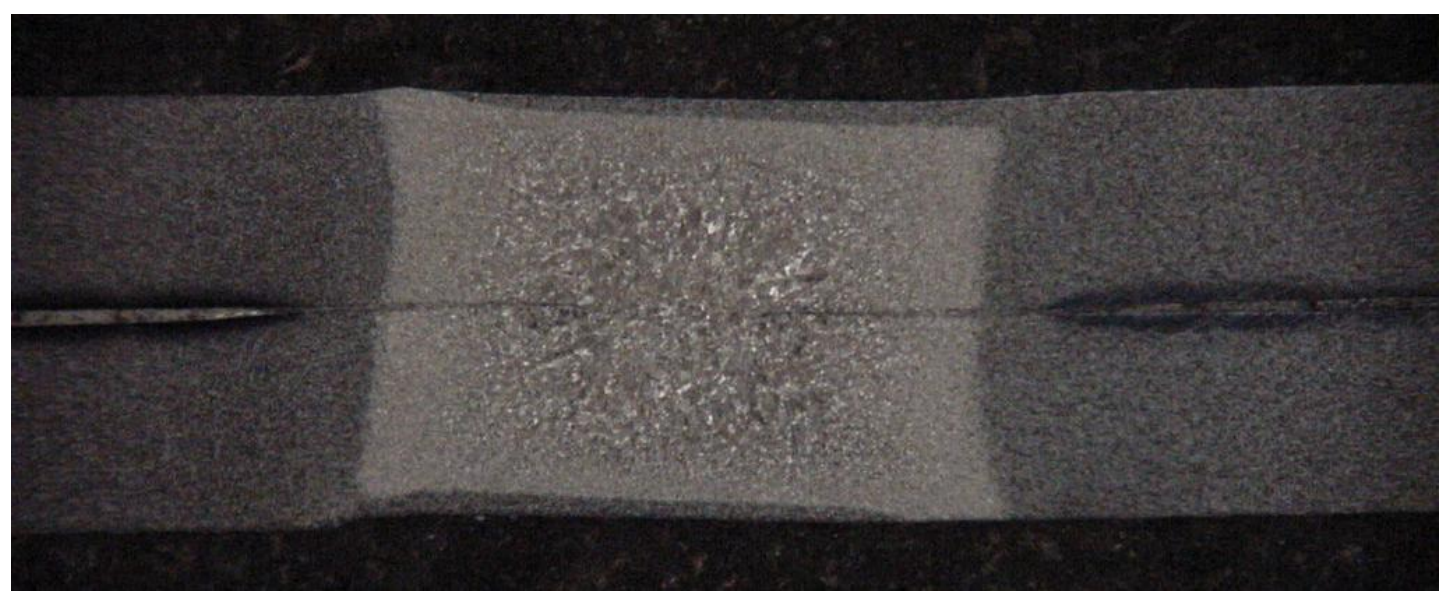

Figura 25: Seção transversal mostrando ponto com diâmetro abaixo do especificado, ataque nital 2\%, 40X (STOCCO, 2003).

O lixamento deve ser executado por meio de uma série de lixas com granulações decrescentes, seguidas por panos embebidos em uma solução à base de pasta de diamante. Em seguida, é realizado um ataque químico por imersão ou aplicação, sendo mais aplicado o uso de uma solução de ácido nítrico, em concentrações que usualmente variam de 2 a $5 \%$. 
Além da morfologia do ponto e eventuais descontinuidades, podem ser observadas e mensuradas neste ensaio outros fatores como o diâmetro do ponto de solda e a sua altura, também definida por penetração (DIN 14329, 2003) - Fig. 26.

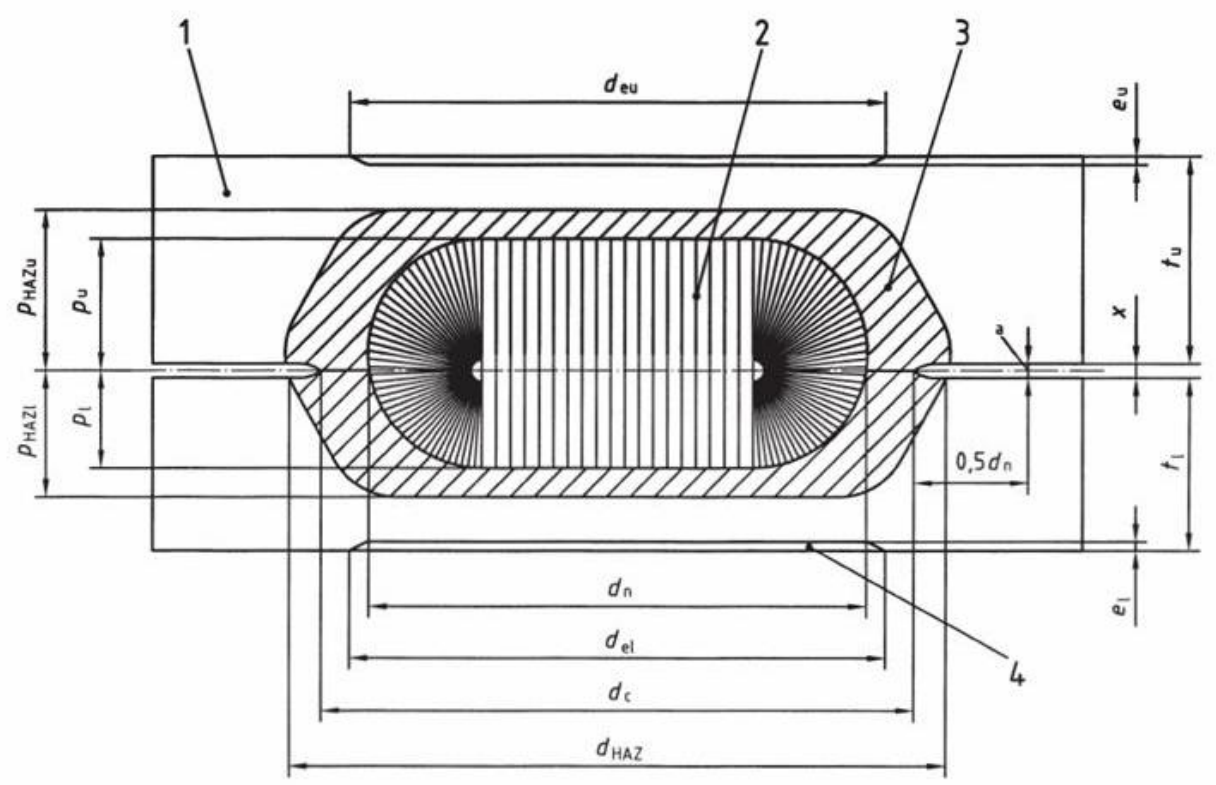

Figura 26: Principais medidas de uma seção transversal de um ponto de solda (DIN 14329, 2003).

De qualquer maneira, o ensaio metalográfico pode ser considerado o ensaio mais preciso na detecção de descontinuidades encontradas na solda por resistência a ponto, e é usualmente aplicado na fase de validação dos parâmetros de soldagem a serem aplicados no processo de união de uma determinada junta, e periodicamente no controle e aferição dos métodos de ensaio utilizados em cada processo, em especial ao ensaio de ultra-som, conforme detalhado nos ensaios realizados no Capítulo 7. 


\section{MÉTODO DE ENSAIO POR ULTRA-SOM}

\subsection{Princípios físicos}

O som é uma oscilação mecânica de matéria, seja em que estado for: sólido, líquido ou gasoso. Sem matéria (vácuo) não pode haver transmissão de som.

Os principais conceitos e propriedades do som podem ser explicados utilizando como exemplo o efeito piezoelétrico de geração de som.

Em 1880, Pierre Curie descobriu que, na superfície de cristais de quartzo com determinada forma, se geram tensões elétricas sob esforços de tração e compressão. A alteração dos esforços mecânicos e deformações alteram as tensões de forma correspondente. O processo é reversível; aplicando tensão, o cristal contrai-se ou expande-se. Aplicando uma tensão alternada, a superfície do cristal oscila para cima e para baixo com um ritmo igual, produzindo uma onda ultra-sônica.

O ultra-som distingue-se do som audível (LEITE, 1977) conhecido apenas em sua frequiência. O ouvido humano capta frequiências de aproximadamente $16 \mathrm{~Hz}$ a 18 $\mathrm{KHz}$. Ondas com uma freqüências superiores a $16 \mathrm{KHz}$ são designadas como ultrasons. Há ainda que referir que o som abaixo de $16 \mathrm{~Hz}$, denominado "infra-som", também não é perceptível para o ouvido humano como som audível. Quanto maior a amplitude, mais energia tem o som, ou seja, mais alto ele é.

A capacidade dos transdutores para utilização nas técnicas de controle por ultra-som conhecidas se situam entre 0,5 a $25 \mathrm{MHz}$. Para inspeção de soldagem por resistência a ponto a faixa de utilização dos transdutores está entre 15 a $20 \mathrm{MHz}$.

\subsection{Efeito Piezoelétrico}

Diversos materiais (cristais) apresentam o efeito piezoelétrico. Se tomarmos uma lâmina de certo formato (placa) e aplicarmos uma pressão sobre o mesmo, surgem em sua superfície cargas elétricas. O efeito inverso também é verdadeiro: se aplicarmos dois eletrodos sobre as faces opostas de uma placa de cristal 
piezoelétrico, de maneira que possamos carregar as faces eletricamente, a placa comporta-se como se estivesse sobre pressão e diminui de espessura. O cristal piezoelétrico pode transformar a energia elétrica alternada em oscilação mecânica e transformar a energia mecânica em elétrica.

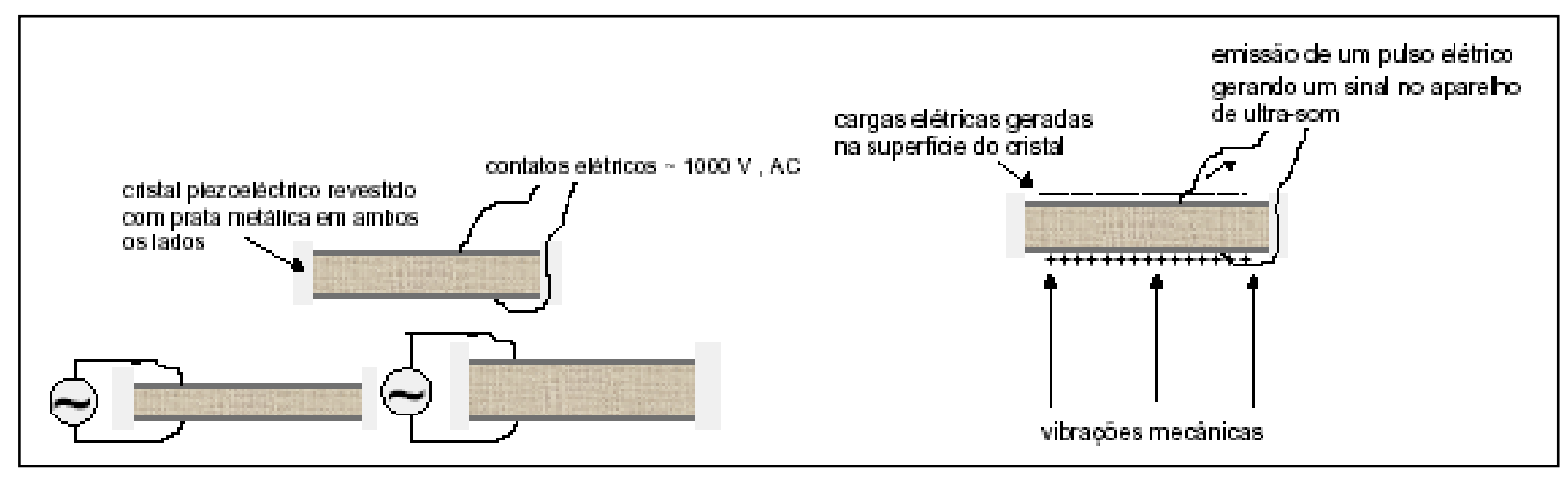

Figura 27 - Efeito Piezoelétrico (ABENDI, 2008)

A figura 27 mostra a contração e expansão do cristal quando submetido a uma tensão alternada na mesma freqüência ultra-sônica emitida pelo cristal. É um processo de transformação da energia elétrica em energia mecânica

Tal fenômeno é obtido aplicando-se eletrodos no cristal piezoelétrico com tensão elétrica alternada da ordem de $1000 \mathrm{~V}$, de maneira que o mesmo se contrai e se estende ciclicamente. Se tentarmos impedir esse movimento a placa transmite esforços de compressão as zonas adjacentes, emitindo uma onda longitudinal, cuja forma depende da freqüência de excitação e das dimensões do cristal.

O tamanho da deflexão máxima de uma oscilação é designado amplitude. Quanto maior a amplitude, mais energia tem o som, ou seja, mais alto ele é. A comparação entre amplitudes de sons é realizada na unidade decibel (dB). 


\subsection{Tipos de oscilação e tipos de ondas}

Um modelo simples (ALICH, 2001) descreve a estrutura de um corpo cristalino sólido. As partículas de massa (átomo e moléculas) estão regularmente ordenadas e ligadas umas às outras por forças de ligação elásticas, representadas na figura 28 por molas helicoidais. Nesses corpos podem propagar-se ondas cortantes (ondas transversais) e ondas de pressão (ondas longitudinais).

Por outro lado, em líquidos e gases, as partículas de massa não estão sujeitas a uma determinada posição de equilíbrio, podendo mover-se mais ou menos livremente. Alterações da densidade causam nestes casos forças elásticas contrárias que permitem a transmissão de ondas sonoras. Nesses meios apenas podem propagar-se ondas de pressão (ondas longitudinais).

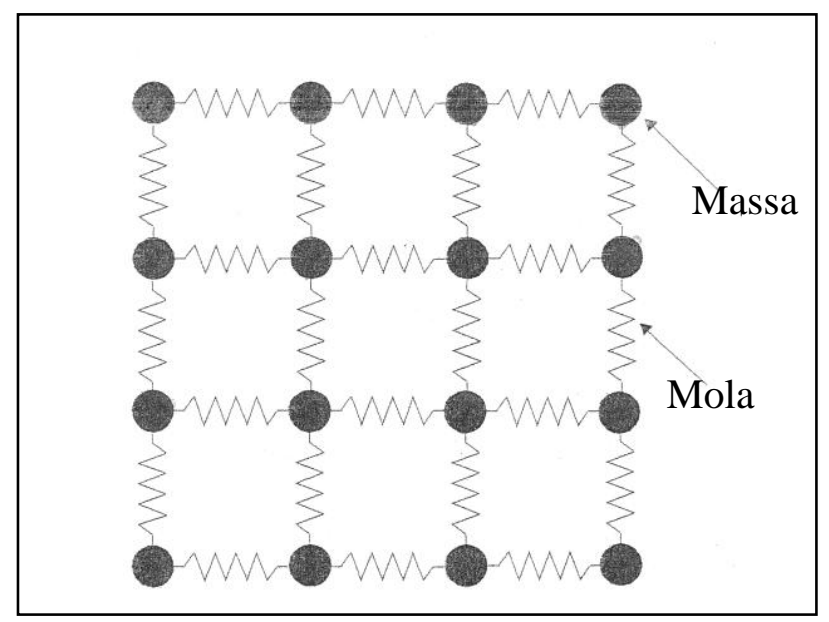

Figura 28 - Modelo plano de um corpo sólido (ALICH, 2001)

\subsubsection{Ondas Longitudinais}

O movimento das partículas de massa na substância é propagado de certas maneiras e direções. Este movimento resulta em um trem de onda mecânica, seja como onda longitudinal ou como uma onda transversal. Uma onda longitudinal é obtida quando em um corpo de ensaio, as partículas de massa próxima à superfície são impulsionadas perpendicularmente à mesma. O primeiro plano de partículas é defletido e transfere sua energia cinética para os próximos planos de partículas. Se as 
interligações de todas as partículas fossem positivas todos os planos seriam defletidos ao mesmo tempo, isto é, seus movimentos estariam em fases iguais. Entretanto, desde que as partículas de massa estão interligadas elasticamente, os próximos planos de partículas de massa ficarão retardados de maneira que se obtêm a seguinte figura, quando se interrompe o movimento de um dado instante (Figura 29).

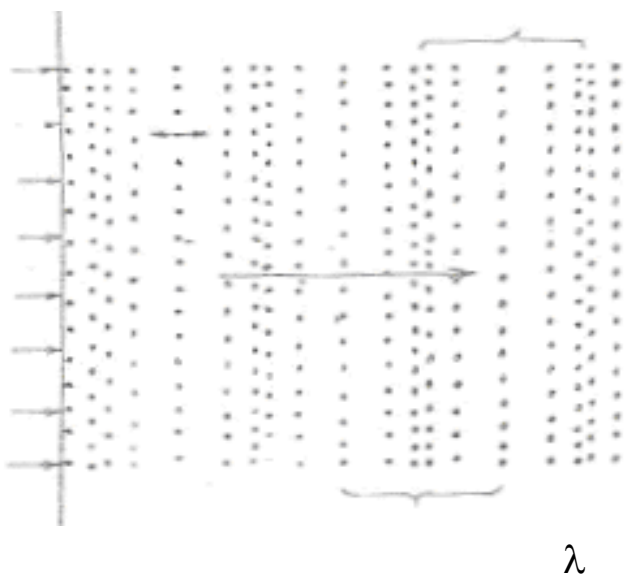

Figura 29 - Representação do deslocamento da onda longitudinal (LEITE, 1977)

Em distâncias iguais, existem compressões de planos de partículas de massa. Entre eles se encontram zonas com grandes distâncias entre os planos de partículas. As distâncias entre 2 compressões e 2 diluições são iguais. Elas são designadas como o comprimento da onda $\lambda$ (lambda) da onda longitudinal. As zonas de compressão e de diluição movem-se através do corpo de prova com uma certa velocidade, que é a velocidade da onda longitudinal.

Essa velocidade do som é uma constante de material, isto é, ela difere de acordo com o material no qual a onda é propagada. Assim ela pode ser considerada constante em um material totalmente homogêneo. 
Exemplo de velocidades de som $\mathrm{v}_{\mathrm{L}}$ de propagação de ondas longitudinais.

Ar :

$$
\mathrm{v}_{\mathrm{L}}=330 \mathrm{~m} / \mathrm{s}
$$

Água :

$$
\mathrm{v}_{\mathrm{L}}=1.480 \mathrm{~m} / \mathrm{s}
$$

Óleos para motores :

$$
\mathrm{v}_{\mathrm{L}}=1.470 \mathrm{~m} / \mathrm{s}
$$

Ferro fundido :

$$
\mathrm{v}_{\mathrm{L}}=3.500 \mathrm{~m} / \mathrm{s}
$$

Aço :

$$
\mathrm{v}_{\mathrm{L}}=5.920 \mathrm{~m} / \mathrm{s}
$$

Alumínio :

$$
\mathrm{v}_{\mathrm{L}}=6.320 \mathrm{~m} / \mathrm{s}
$$

Observando-se os movimentos de uma onda é possível notar que existe, além do comprimento de onda e a velocidade do som, a freqüência f. A escolha da freqüência adequada é muito importante no ensaio ultra-sônico. A correlação matemática dos três elementos definidos é:

$$
\mathbf{v}_{\mathbf{L}}=\mathbf{f} \cdot \lambda
$$

Como a velocidade do som é uma constante do material, a escolha de uma certa freqüência define o comprimento da onda ultra-sônica.

\subsubsection{Onda transversal (Onda de cisalhamento)}

Uma onda transversal é gerada quando as partículas de massa próxima à superfície são impulsionadas em uma direção paralela à superfície. Quando se olha a Figura 31, representando o trem de ondas, verifica-se que agora os planos de partículas permanecem a distâncias constantes um do outro, e ainda, que os planos movem-se lateralmente um contra o outro. Desde que exista um movimento de cisalhamento entre os planos, as ondas transversais são também chamadas ondas de cisalhamento. 


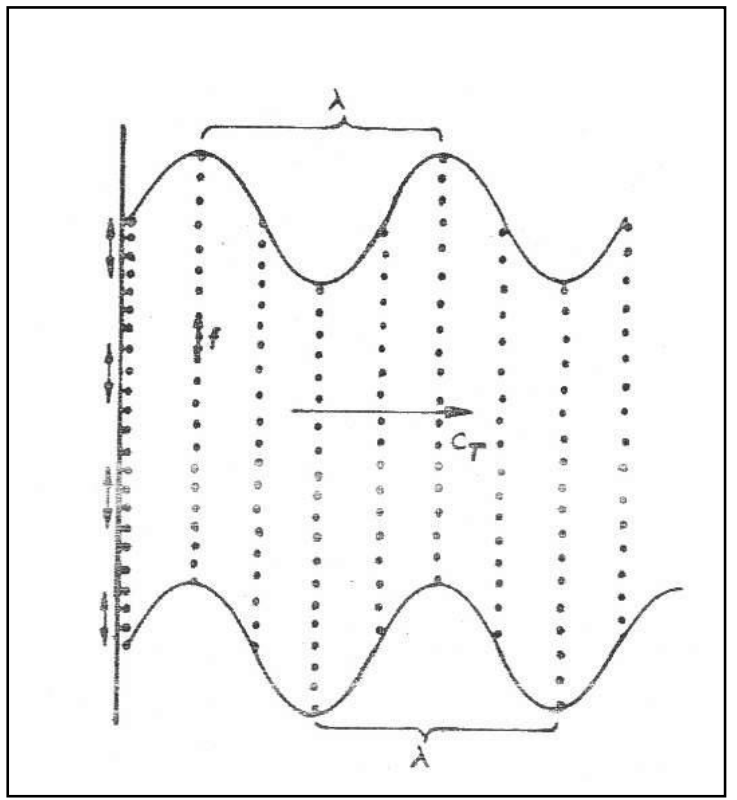

Figura 30 - Representação do deslocamento da onda transversal (LEITE, 1977)

Quando se interligam os pontos mais distantes de planos simples, aparecem os picos e os vales de ondas.

Observando-se o movimento dinâmico do trem de ondas, verifica-se que o pico da onda bem como o seu vale permanece a certa distância constante durante o seu movimento através do material em ensaio.

Analogamente, para as condições das ondas longitudinais, a distância entre dois vales ou dois picos de ondas consecutivas é o comprimento da onda $\lambda$ da onda transversal.

A velocidade com a qual o pico e o vale de uma onda se movem através do corpo é a velocidade $\mathrm{v}_{\mathrm{T}}$ da onda transversal. Outra vez a velocidade do som é uma constante do material. Em todos os meios as velocidades das ondas transversais e longitudinais diferem significativamente. 
Exemplo de velocidades de som $\mathbf{v}_{\mathbf{T}}$ de propagação de ondas transversais.

Ar :

Água :

Ferro fundido cinzento (lamelar) :

Aço :

Alumínio :

$$
\begin{aligned}
& \mathrm{v}_{\mathrm{T}}=0 \mathrm{~m} / \mathrm{s} \\
& \mathrm{v}_{\mathrm{T}}=0 \mathrm{~m} / \mathrm{s} \\
& \mathrm{v}_{\mathrm{T}}=2.650 \mathrm{~m} / \mathrm{s} \\
& \mathrm{v}_{\mathrm{T}}=3.230 \mathrm{~m} / \mathrm{s} \\
& \mathrm{v}_{\mathrm{T}}=3.130 \mathrm{~m} / \mathrm{s}
\end{aligned}
$$

A frequiência outra vez indica o número de vibrações por segundo, feito pelas partículas de massa. A equação acima mencionada referente à correlação entre comprimento de onda, velocidade do som e freqüência aplica-se também aqui, mas note-se que deve ser usada a velocidade da onda transversal. Observando-se as figuras das ondas longitudinais e transversais, pode-se perceber mais uma característica destes tipos de ondas: no caso das ondas longitudinais as partículas de massa vibram na direção de propagação das oscilações; no caso da onda transversal, elas vibrarão perpendicularmente a ela.

A razão pela qual a velocidade das ondas transversais é zero na água e no ar, isto é, não são propagadas nestes materiais, é fácil de ser compreendido. Para propagar a onda transversal, as forças de impulsão das ondas de cisalhamento devem ser transferidas, o que é impossível nos líquidos e gases.

\subsubsection{Tipos de cristais}

Materiais piezoelétricos são: o quartzo, o sulfato de lítio, o titanato de bário, o metaniobato de chumbo.

O Quartzo é um material piezoelétrico mais antigo, translúcido e duro como o vidro sendo cortado a partir de cristais originários no Brasil. Sulfato de Lítio é um cristal sensível à temperatura e pouco resistente. Titanato de Bário e metaniobato de chumbo são materiais cerâmicos que recebem o efeito piezoelétrico através de polarização. 
Esses dois cristais são os melhores emissores, produzindo impulsos ou ondas de grande energia, se comparadas com aquelas produzidas por cristais de quartzo.

Para a inspeção ultra-sônica, interessa não só a potência de emissão, mas também a sensibilidade da recepção (resolução). A frequiência ultra-sônica gerada pelo cristal dependerá da sua espessura, cerca de $1 \mathrm{~mm}$ para $4 \mathrm{MHz}$ e $2 \mathrm{~mm}$ para 2 $\mathrm{MHz}$.

Os cristais acima mencionados são montados sobre uma base de suporte (bloco amortecedor) e junto com os eletrodos e a carcaça externa constituem o transdutor ou cabeçote propriamente dito. Existem três tipos usuais de transdutores: reto ou normal, o angular e o duplo - cristal.

\subsection{Transdutores}

O transdutor de controle é o dispositivo que permite a geração das ondas ultra-sônicas, utilizando um cristal piezoelétrico restrito em uma carcaça, como demonstram as Figuras 32 e 33.

O campo sonoro de um transdutor, tal como representado na Figura 31, começa com um feixe ligeiramente cônico de pressão sonora de grande alteração, o campo próximo, cujo comprimento $\mathrm{N}$ é descrito de acordo com a fórmula abaixo, e que está relacionado com o diâmetro do oscilador Ds e o comprimento da onda no objeto de controle $\lambda$.

$$
\begin{gathered}
\mathrm{N}=\frac{\mathrm{D}_{\mathrm{s}}^{2}}{4 . \lambda} \\
N=\frac{D_{s}^{2} \bullet f}{4 \bullet c}=\frac{100 \bullet 6000000}{4 \bullet 6000000}=25 \mathrm{~mm}
\end{gathered}
$$




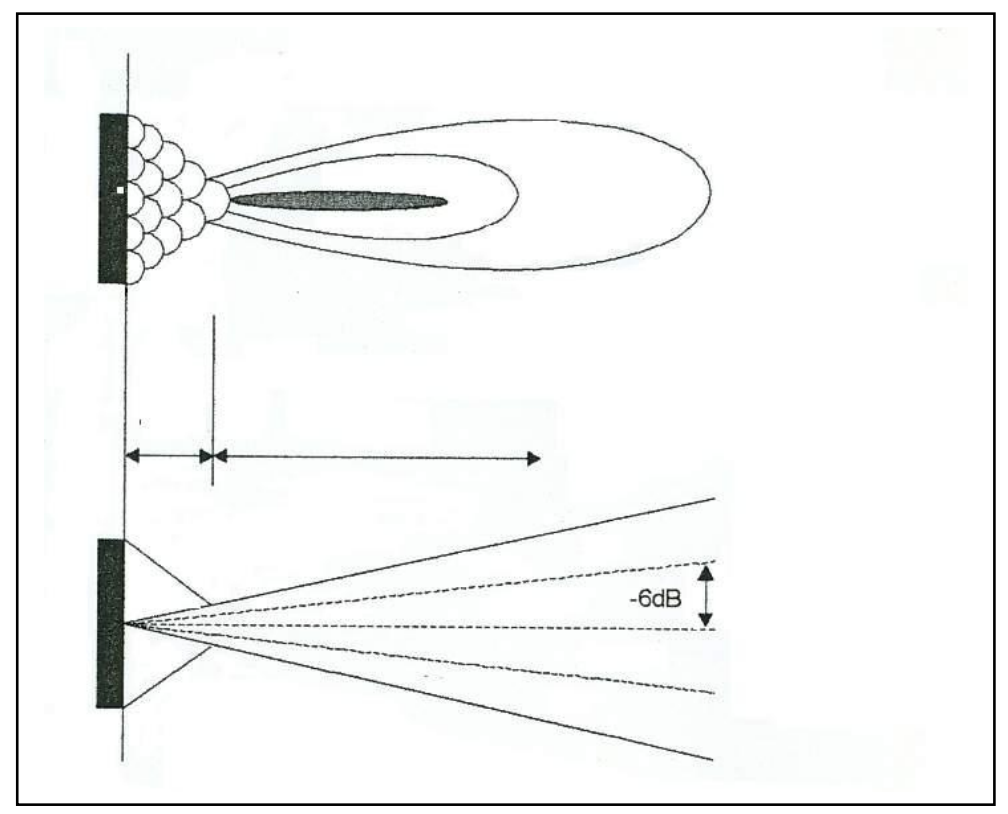

Figura 31 - Representação do campo sonoro (ALICH, 2001)

Segue-se o chamado campo afastado, cujo ângulo de abertura $v$ também depende do diâmetro do oscilador e do comprimento da onda e que se abre como um farol. No caso de transdutores de controle verticais com osciladores circulares, a pressão sonora máxima no campo afastado situa-se na linha central do feixe sonoro e é inversamente proporcional à distância em relação ao oscilador. Como já foi referido, pressões sonoras e amplitudes de eco são indicadas em decibéis (dB), uma unidade logarítmica de comparação. Aplica-se a seguinte fórmula:

$$
\Delta \mathrm{p}[\mathrm{dB}]=20 . \log \frac{\mathrm{P}_{2}}{\mathrm{P}_{1}}
$$

\subsubsection{Transdutores Normais ou retos}

São assim chamados os transdutores monocristais geradores de ondas longitudinais normais à superfície de acoplamento.

Os transdutores normais são construídos a partir de um cristal piezoelétrico colado num bloco rígido denominado de amortecedor e sua parte livre protegida ou uma membrana de borracha ou uma resina especial. O bloco amortecedor tem função de servir de apoio para o cristal e absorver as ondas emitidas pela face colada a ele.

O transdutor emite um impulso ultra-sônico que atravessa o material a inspecionar e refletem nas interfaces, originando sinais em uma tela, conhecidos por 
ecos. Estes ecos retornam ao transdutor e geram, no mesmo, o sinal elétrico correspondente.

A face de contato do transdutor com a peça deve ser protegida contra desgaste mecânico podendo utilizar membranas de borracha finas e resistentes ou camadas fixas de epóxi enriquecido com óxido de alumínio.

Em geral os transdutores normais são circulares, com diâmetros de 3 a 24 mm, com freqüência de 0,5 a $25 \mathrm{MHz}$. Outros diâmetros e freqüências existem, porém para aplicações especiais.

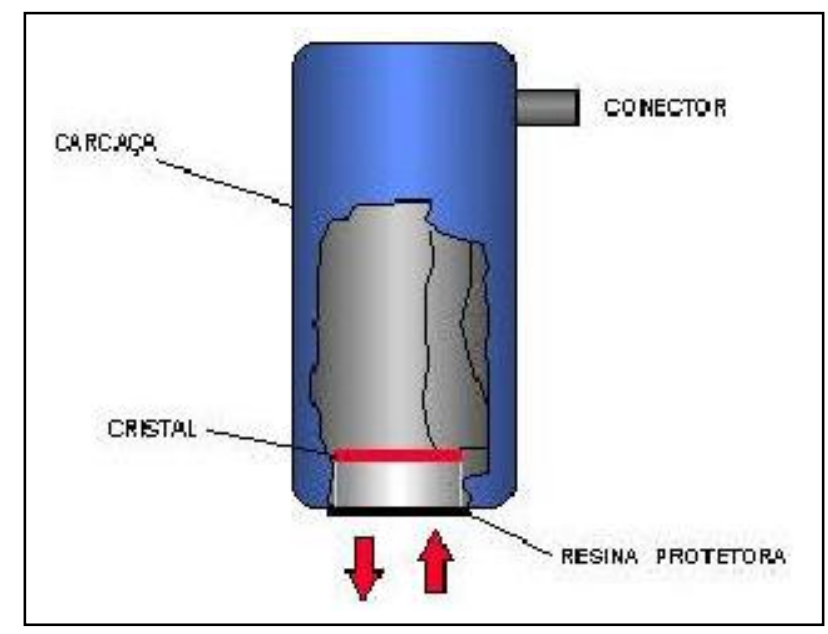

Figura 32 - Transdutor normal ou reto (ABENDI, 2008)

O transdutor normal tem sua maior utilização na inspeção de peças com superfícies paralelas ou quando se deseja detectar descontinuidade na direção perpendicular à superfície da peça. É o exemplo de chapas, fundidos e forjados.

\subsubsection{Transdutores Angulares}

A rigor, diferem dos transdutores retos ou normais pelo fato do cristal formar um determinado ângulo com a superfície do material. $\mathrm{O}$ ângulo é obtido, inserindo uma cunha de plástico entre o cristal piezoelétrico e a superfície. A cunha pode ser fixa, sendo então englobada pela carcaça ou intercambiável. Neste último caso temos um transdutor normal que é preso com parafusos que fixam a cunha à carcaça. Como na prática operamos normalmente com diversos ângulos que podem variar entre $35 \mathrm{e}$ 
80 graus, esta solução é mais econômica já que um único transdutor com várias cunhas é de custo inferior, porém necessita de maiores cuidados no manuseio.

O ângulo nominal, sob o qual o feixe ultra-sônico penetra no material, é determinado de acordo com o material a ser inspecionado, devendo ser calculado utilizando a Lei de Snell. A mudança do ângulo deve-se à mudança de velocidade no meio.

O cristal piezoelétrico com dimensões que podem variar entre $8 \times 9 \mathrm{~mm}$ até 15 x $20 \mathrm{~mm}$, somente recebe ondas ou impulsos ultra-sônicos que penetram na cunha em uma direção paralela à de emissão. A cunha de plástico funciona como amortecedor para o cristal piezoelétrico, após a emissão dos impulsos.

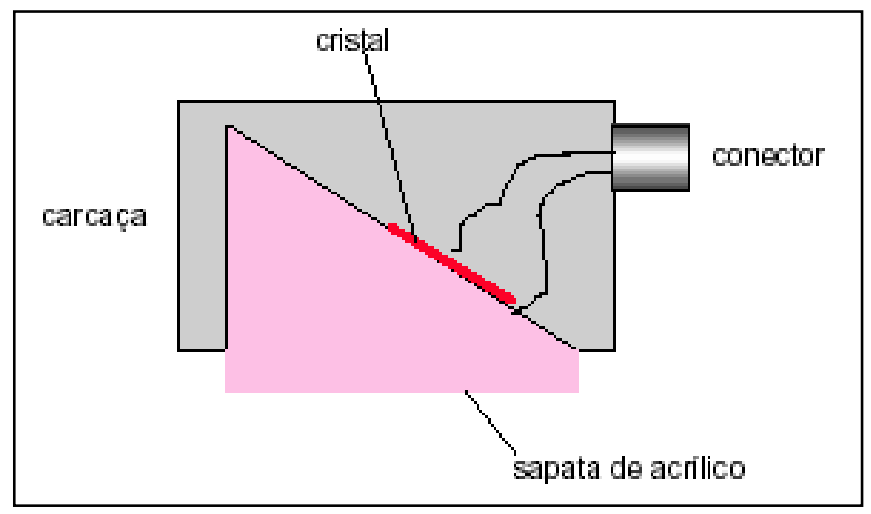

Figura 33 - Transdutor Angular (ABENDI, 2008)

O transdutor angular é muito utilizado na inspeção de soldas e quando a descontinuidade está orientada perpendicularmente à superfície da peça.

\subsubsection{Transdutores Duplo-Cristal}

Existem problemas de inspeção que não podem ser resolvidos nem com transdutores retos nem com angulares. Quando se trata de inspecionar ou medir materiais de reduzida espessura, ou quando se deseja detectar descontinuidades logo abaixo da superfície do material, a "zona morta" existente na tela do aparelho impede uma resposta clara. $\mathrm{O}$ cristal piezoelétrico recebe uma resposta num espaço de tempo curto após a emissão, não tendo suas vibrações suficientemente amortecidas. 
Neste caso, somente um transdutor que separa a emissão da recepção pode ajudar. Para tanto, desenvolveu-se o transdutor de duplo-cristal, no qual dois cristais são incorporados na mesma carcaça, separados por um material acústico isolante e levemente inclinado em relação à superfície de contato. Cada um deles funciona somente como emissor ou somente como receptor, sendo indiferente qual deles exerce qual função. São conectados ao aparelho de ultra-som por um cabo duplo; o aparelho deve ser ajustado para trabalhar agora com 2 cristais.

Os cristais são montados sobre blocos de plástico especial de baixa atenuação. Devido a esta inclinação, os transdutores duplos não podem ser usados para qualquer distância (profundidade). Possuem sempre uma faixa de inspeção ótima, que deve ser observada. Fora desta zona a sensibilidade se reduz. Em certos casos estes transdutores duplos são utilizados com "focalização", isto é, o feixe é concentrado em uma determinada zona do material para a qual se deseja máxima sensibilidade.

O transdutor duplo-cristal é o mais indicado nos procedimentos de medição de espessura por ultra-som.

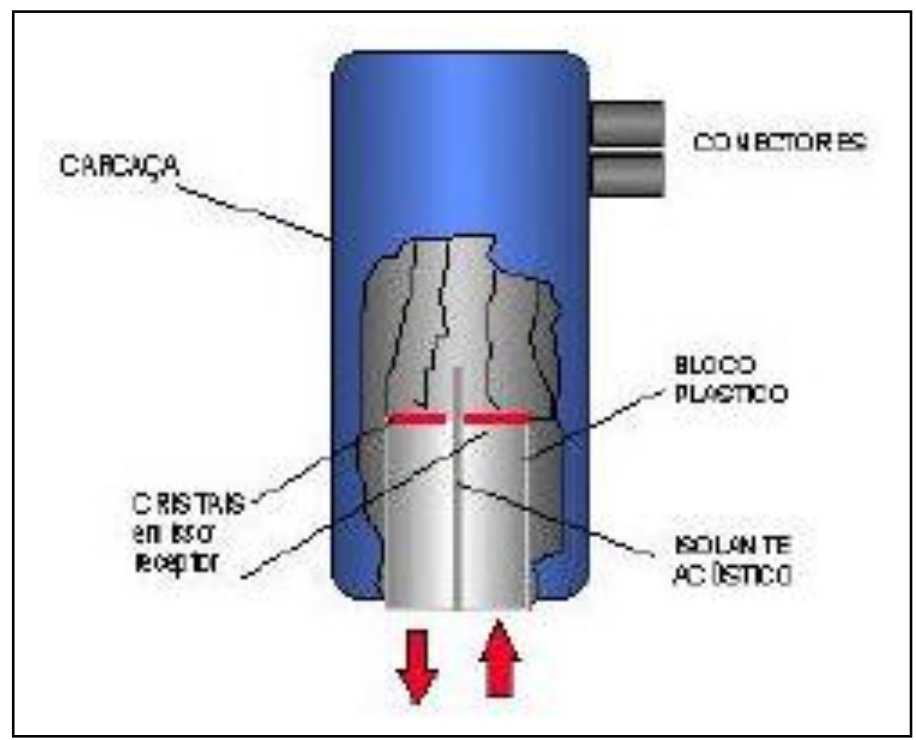

Figura 34 - Transdutor Duplo-Cristal (ABENDI, 2008)

O transdutor duplo-cristal tem sua utilização maior na detecção de descontinuidades próximas da superfície, acima de $3 \mathrm{~mm}$ de profundidade e em 
medição de espessura, em razão do seu feixe sônico ser focalizado. Na ocasião da aquisição desse transdutor, deve se verificar qual a faixa de espessura que se pretende medir, e qual o modelo ideal para esta aplicação. Comportamento de ondas sonoras nas interfaces

\subsection{Resistência da onda (impedância acústica)}

Se uma onda sonora atingir perpendicularmente a interface entre dois meios diferentes, parte desta onda é refletida, parte penetra no segundo meio. Para poder medir esse fenômeno quantitativamente, ou seja, para poder determinar as proporções de reflexão e de penetração, criou-se o conceito de resistência da onda sonora ou impedância acústica.

A Impedância acústica $Z$ é o produto da velocidade $v$ e da densidade $\rho$ do meio em questão.

$$
\mathrm{Z}=\rho . \mathrm{V}
$$

A proporção $\mathrm{R}$ entre a pressão de som refletida e incidente é calculada como a seguir se indica:

$$
\mathrm{R}=\frac{\mathrm{Z}_{2}-\mathrm{Z}_{1}}{\mathrm{Z}_{2}+\mathrm{Z}_{1}}
$$

$\mathrm{Z}_{1}$ : no meio $1 ; \mathrm{Z}_{2}$ : no meio 2

$\mathrm{R}$ é designado fator de reflexão. A proporção $\mathrm{D}$ é designada fator de transmissão entre a pressão do som de transmissão e incidente, é calculado como a seguir se indica:

$$
\mathrm{D}=\frac{2 * \mathrm{Z}_{2}}{\mathrm{Z}_{1}+\mathrm{Z}_{2}}
$$


Observa - se que quanto maior a diferença entre a impedância acústica maior será a quantidade de energia sônica refletida.

Este fenômeno definirá a reflexão da onda sonora e sua aplicação nas técnicas de ensaio ultra-sônicas, conforme demonstrado nos itens a seguir.

\subsection{Técnicas de varredura utilizadas}

\subsubsection{Técnica de Transparência (Through-Transmission mode)}

É uma técnica onde são utilizados dois transdutores separados, um transmitindo e outro recebendo as ondas ultra-sônicas. Neste caso é necessário acoplar os transdutores nos dois lados da peça, de forma que estes estejam perfeitamente alinhados. Neste tipo de inspeção não se pode determinar a posição da descontinuidade, sua extensão, ou localização na peça. É somente um ensaio do tipo passa ou não-passa.

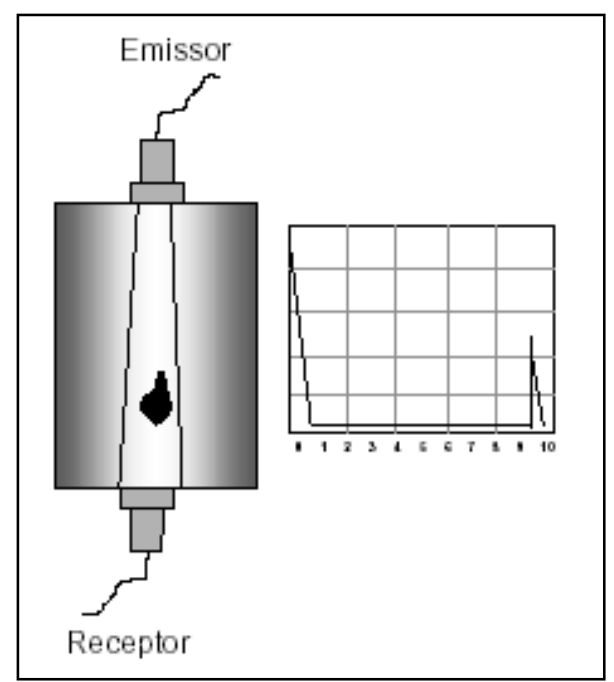

Figura 35- Técnica da transparência (ABENDI, 2008)

A técnica de transparência pode ser aplicada para chapas, juntas soldadas, barras e o intuito destes ensaios é estabelecer um critério comparativo de avaliação do sinal recebido, ou seja, da altura do eco na tela.

A altura do sinal recebido na técnica de transparência varia em função da quantidade e tamanho das descontinuidades presentes no percurso das vibrações 
ultra-sônicas. Sendo assim o inspetor não pode analisar as características das indicações, porém pode comparar a queda do eco com uma peça sem descontinuidades, podendo assim estabelecer critérios de aceitação do material fabricado.

Este método pode ser aplicado a chapas fabricadas em usinas, barras forjadas ou fundidas e, em alguns casos, em soldas.

\subsubsection{Técnica de impulso - eco / incidência perpendicular (pulse-echo mode)}

$\mathrm{Na}$ técnica de impulso-eco, um impulso ultra-sônico é transmitido ao material, sendo medido o tempo de propagação e a intensidade do eco vindo do material. O tempo decorrido entre a emissão do impulso e a recepção do eco pode ser convertido em distância entre o cabeçote de controle e a superfície refletora. A intensidade (altura do eco) é influenciada pelo tamanho, pela posição e pela forma da superfície refletora.

A distância e a intensidade são apresentadas no monitor do aparelho de controle ultra-sônico. No instante $t=0$ segundo o som é transmitido ao componente. O som percorre o componente até atingir uma descontinuidade U. O som é então refletido em parte ou por completo voltando para o transdutor de controle. O ponto em que som atinge a descontinuidade é indicado no monitor por meio de um sinal (eco). Essa distância é designada distância sonora e corresponde à metade da distância que o som realmente percorreu. $\mathrm{O}$ verdadeiro percurso é designado percurso sonoro.

Se a velocidade do som no objeto de controle for conhecida, pode se calcular a distância entre transdutor e o ponto de reflexão a partir do tempo de propagação. Com a ajuda de uma escala pode-se ler essa distância diretamente no monitor, ajustando-se o aparelho de controle ultra-sônico. 
Se na área do feixe sonoro não houver qualquer descontinuidade, além do impulso de transmissão $\mathrm{S}$ só aparece no monitor o eco de superfície limite $\mathrm{R}$, cuja distância relativa ao impulso de transmissão corresponde à espessura total do objeto de controle (se o aparelho estiver devidamente ajustado), tal como a Figura 36 indica.

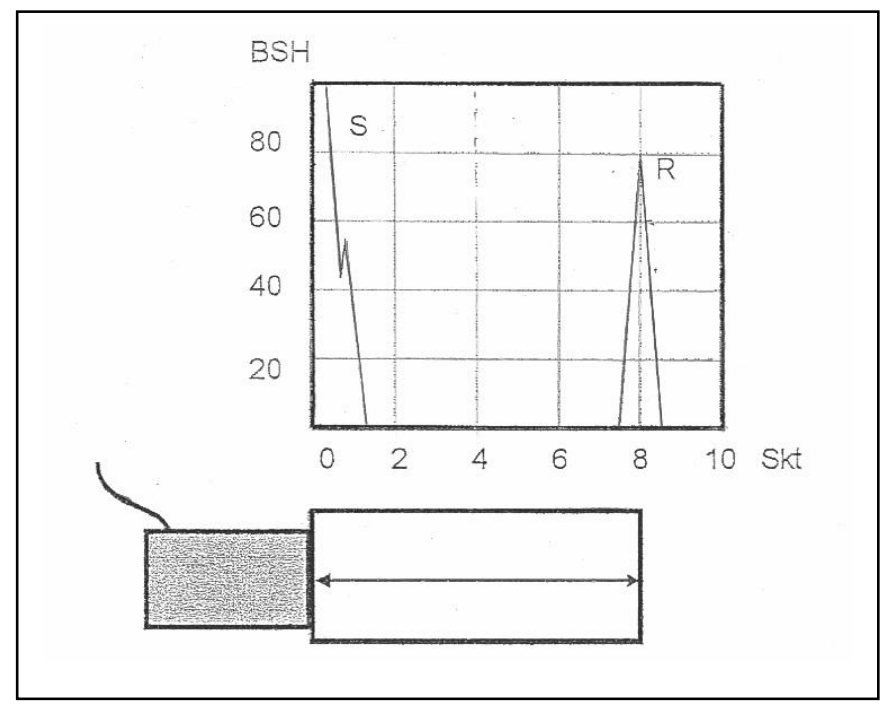

Figura 36 - Imagem ultra-sônica sem falha (ALICH, 2001)

Se na área do feixe sonoro houver uma descontinuidade perpendicular aos raios sonoros que reflete uma parte das ondas ultra-sônicas, entre o impulso de transmissão e o eco de superfície limite surge o eco de descontinuidade U correspondente, e a partir dessa posição é possível ler no monitor a distância entre a falha e o transdutor de controle. O próprio eco de superfície limite pode tornar-se menor, vide Figura 37. 


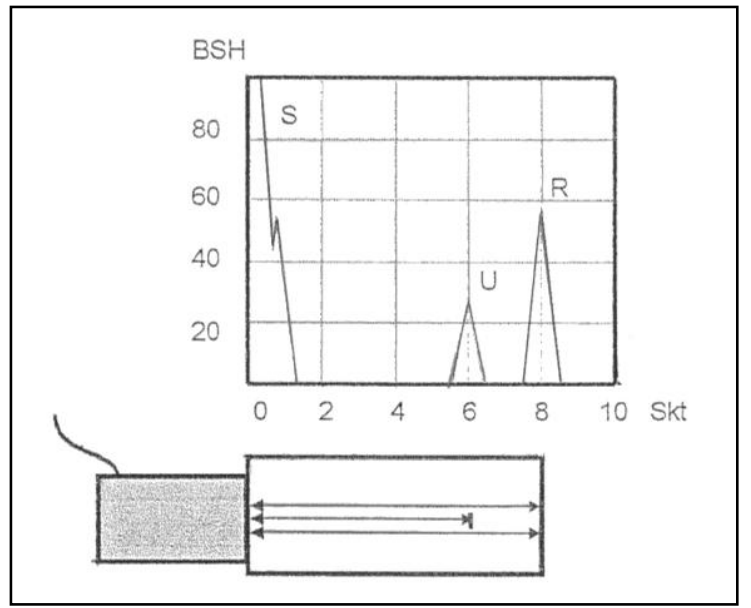

Figura 37 - Imagem ultra-sônica com descontinuidade (ALICH, 2001)

Se o feixe sonoro encontrar uma descontinuidade que cobre o feixe sonoro completo, o eco de superfície desaparece por completo, só podendo ser visto um eco de descontinuidade, tal como na Figura 38.

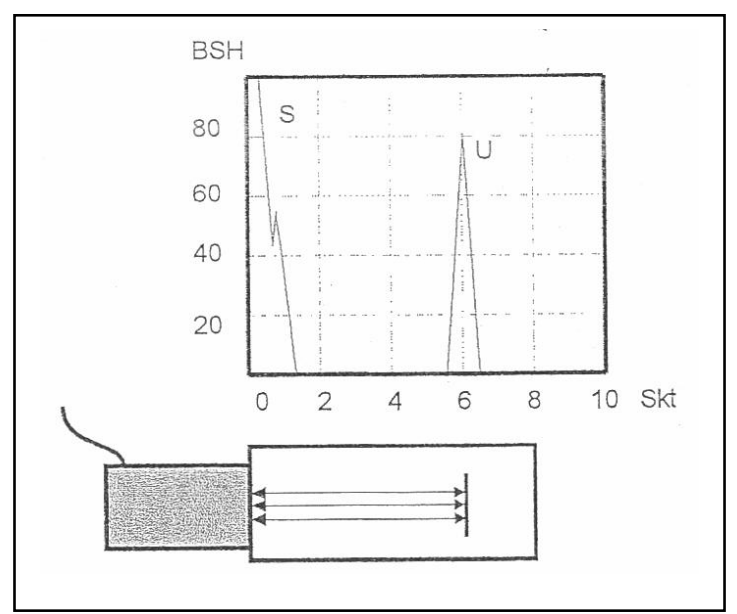

Figura 38 - Imagem ultra-sônica sem eco de superfície limite (ALICH, 2001)

Se o feixe sonoro detectar várias descontinuidades, cuja distância umas das outras seja superior à largura das imagens correspondentes, eles são visualizadas por imagens separadas, vide Figura 39. 


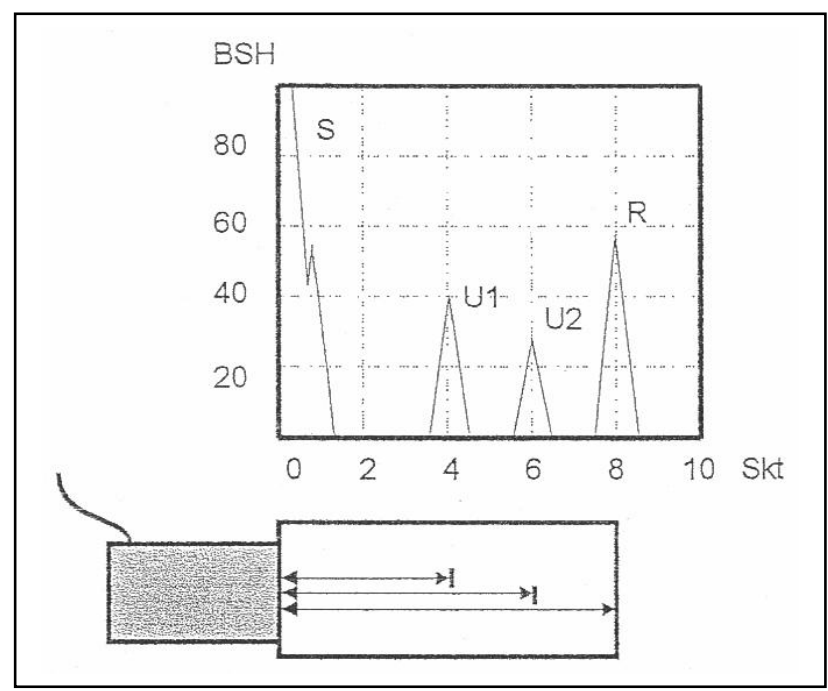

Figura 39 - Imagem ultra-sônica com várias descontinuidades (ALICH, 2001)

Se uma grande descontinuidade plana não ocorrer perpendicular aos raios sonoros, eles não são refletidos perpendicularmente ao transdutor, e não podem ser recebidos. No monitor não são visualizados ecos de descontinuidade nem ecos de superfície limite, como-se pode ver na Figura 40.

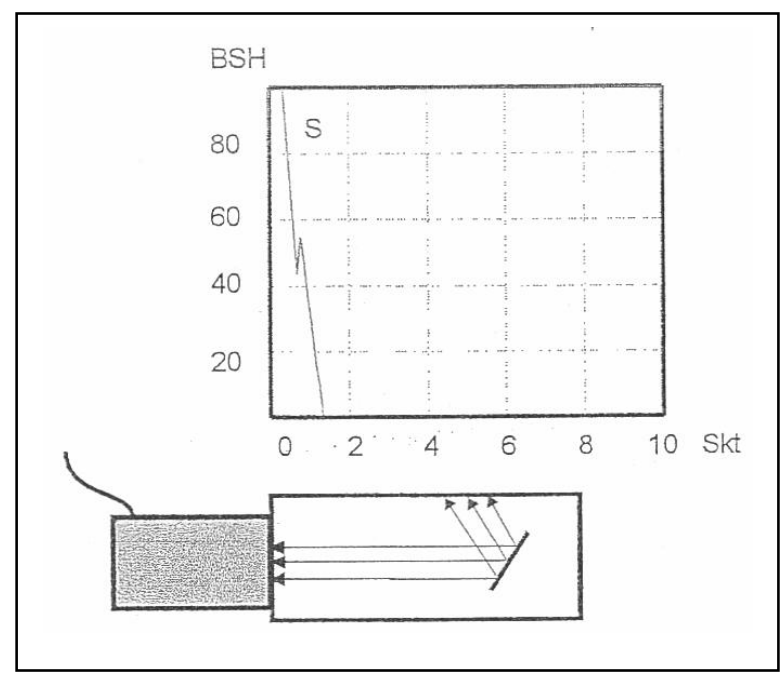

Figura 40 - Imagem ultra-sônica sem ecos de descontinuidade nem ecos de superfície limite (ALICH, 2001).

A indicação que se segue é importante como complemento dos exemplos. Só uma determinada parte do som do eco recebido passa através da superfície de contato entre o transdutor de controle e a peça de controle. Uma grande parte é refletida e efetua o mesmo percurso ao longo do componente. Assim, as imagens repetidas da superfície limite R2, R3, etc, aparecem no monitor com os intervalos 
correspondentes, de acordo com a espessura da parede do componente, como se vê na Figura 41.

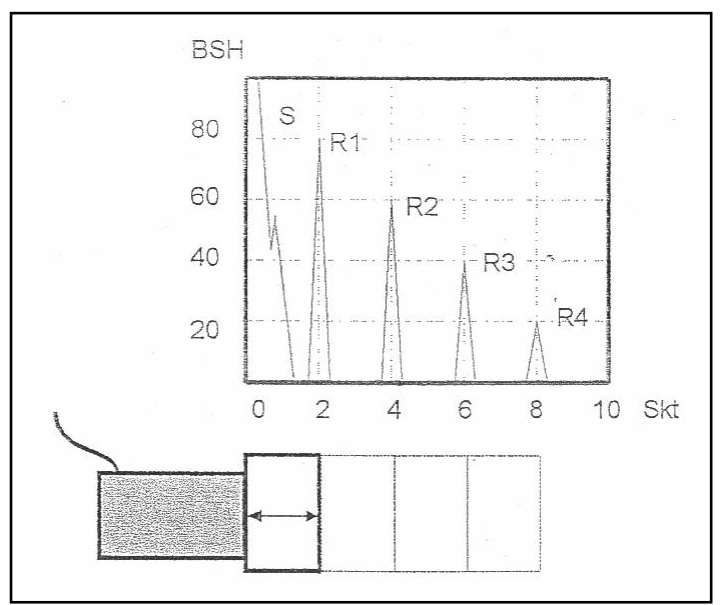

Figura 41 - Ecos múltiplos (ALICH, 2001). 


\section{MÉTODO DE ENSAIO POR ULTRA-SOM APLICADO A SOLDAGEM POR RESISTÊNCIA A PONTO}

A aplicação da inspeção ultra-sônica de solda por resistência a ponto foi discutida sob vários detalhes (Mansour, 1988; Welding Design \& Fabrication, July 1988; Welding Design \& Fabrication, March 1987). O princípio por trás desta técnica consiste basicamente em distinguir a qualidade da solda através da interpretação de uma série de sinais ultra-sônicos, ou padrões de eco, originários da solda testada. A facilidade de aplicação desta técnica é certamente um ponto de discussão (Hain, 1988), especialmente devido a questão da interpretação destes padrões de eco, situação que apresentou sensível melhora com o advento dos equipamentos $2 \mathrm{D}$ e $3 \mathrm{D}$, mostrados a seguir.

\subsection{Transdutor de simples elemento (A-scan)}

Sua utilização é baseada na detecção das reflexões da junta soldada em conjunto com a atenuação destes sinais devido aos grãos grosseiros originados na lentilha de solda. Em termos simples, as imagens mostradas a seguir ilustram as características de sinal obtido em diversas soldas, e vistos num equipamento de ultrasom.

\subsubsection{Aparelho}

Por meio de um gerador de impulsos, são ativados no transmissor numa sucessão rápida de curtos impulsos elétricos que geram impulsos sonoros (impulsos de transmissão SI) no transdutor, dependendo da característica acústica deste último. Os impulsos acústicos que voltam da peça de trabalho são convertidos pelo mesmo transdutor de controle em sinais elétricos analógicos e enviados para o amplificador, conforme demonstra a Figura 42. 


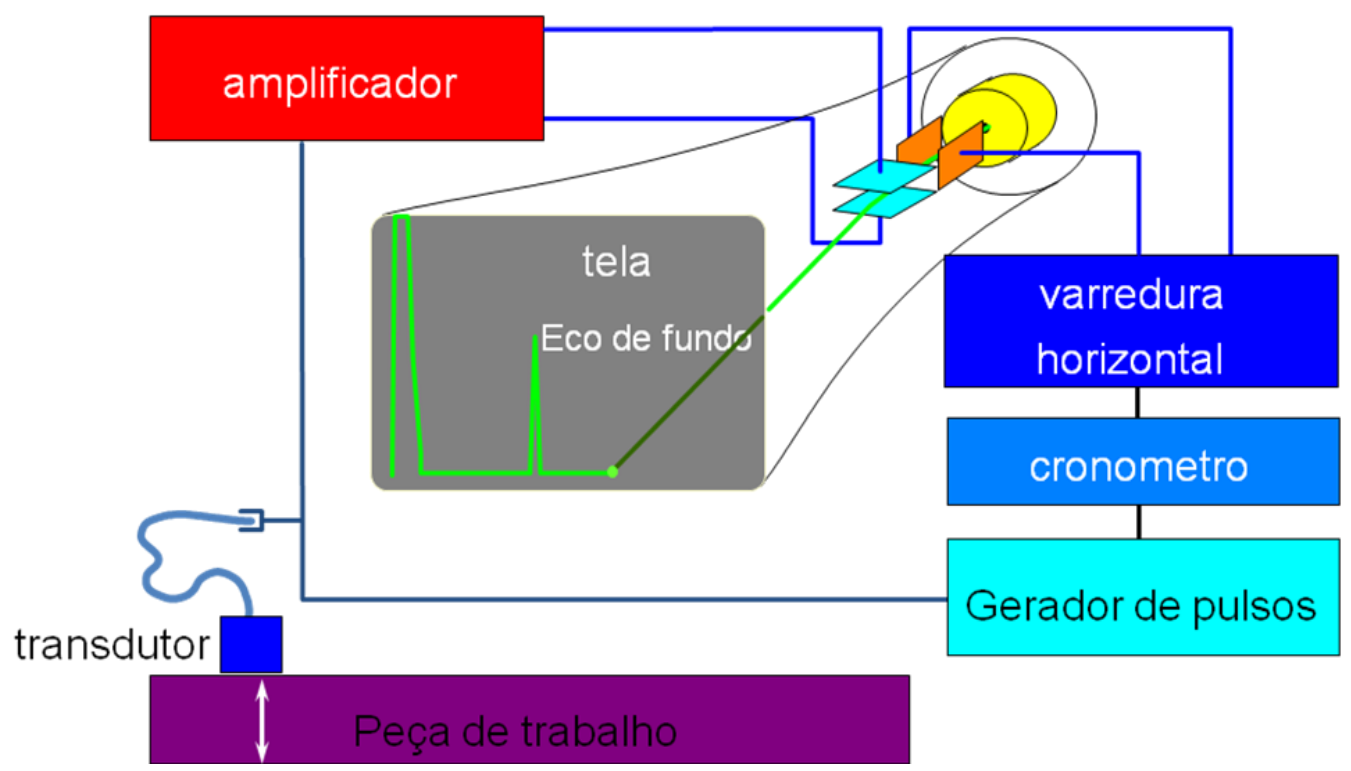

Figura 42: Estrutura esquemática de um aparelho analógico de controle ultra-sônico (Krautkramer, 2008)

O tempo de propagação e a amplitude dos vários impulsos são apresentados em um monitor. O monitor começa com o impulso de transmissão à esquerda, e o raio de eletrodos é defletido para a direita em função do tempo. Assim, a reflexão da superfície da falha é visualizada num intervalo relativo ao eco de superfície limite. Isso se repete na transmissão do impulso seguinte. Devido aos curtos tempos de propagação, pode trabalhar-se de 100 a 1.000 impulsos por segundo, dependendo da velocidade do som e das margens de controle, sendo apresentada uma imagem parada para o olho humano. Esta é denominada freqüência de seqüência de impulsos, e é estabelecida pelo fabricante de aparelhos analógicos, sendo alterada pelo ajuste da margem de controle. Quanto mais rapidamente os impulsos se seguirem uns aos outros, mais clara é a imagem. No entanto, o intervalo entre dois impulsos sucessivos tem que ser suficiente grande para a reflexão ativada pelo impulso anterior ter desaparecido por completo. Se assim não for, podem ocorrer os chamados "ecos fantasmas", sobretudo no caso de materiais bons condutores sonoros e com maior amplificação. Nesse caso, uma seqüência de impulsos atinge a anterior e simula uma falha, como indicado na Figura 43. 


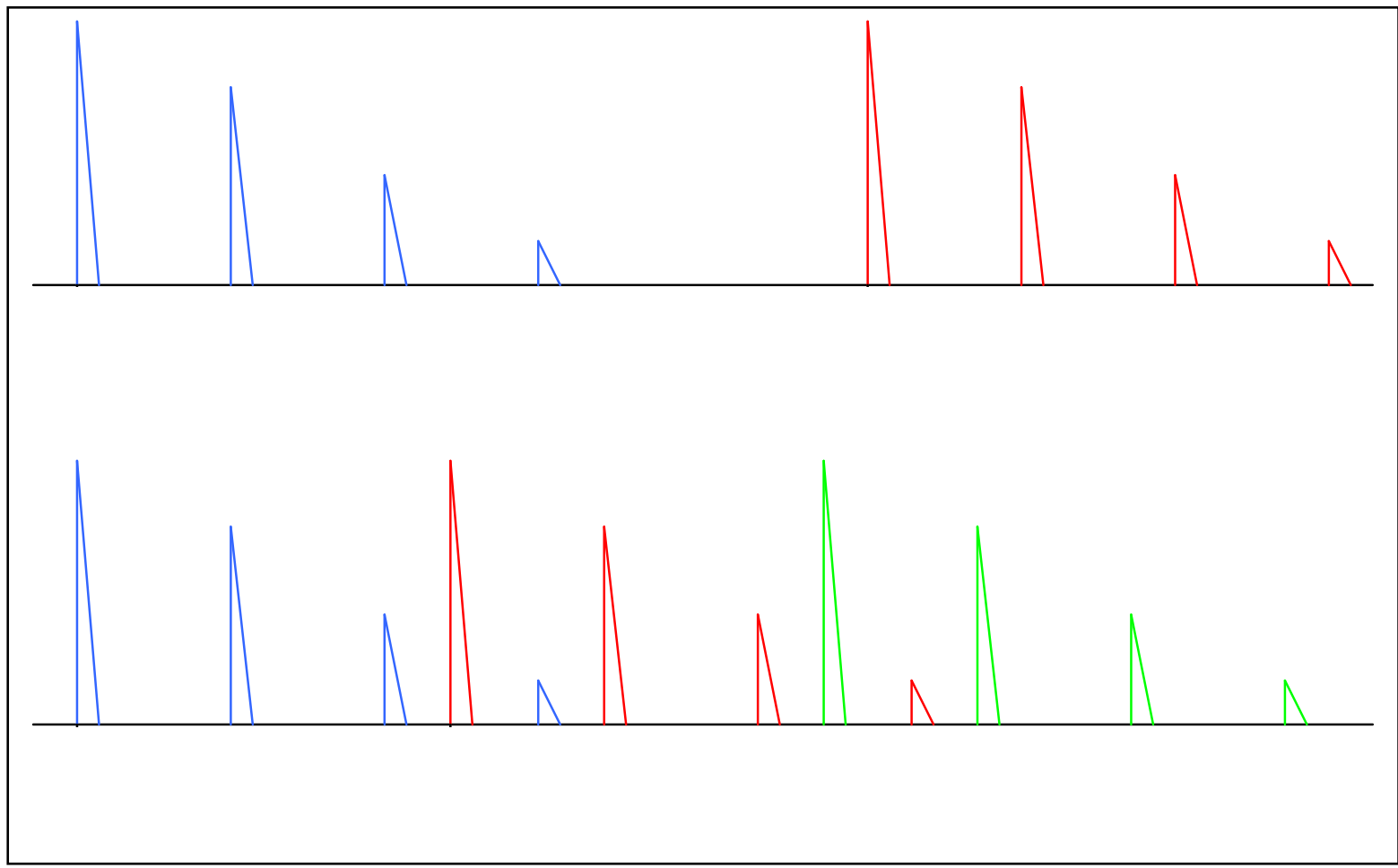

Figura 43 - Criação de ecos fantasmas no caso de sequiência de impulsos inadequada

As alturas de eco são alteradas pelo regulador de amplificação calibrado em dB. Para duplicar ou reduzir para metade a altura de eco, é necessária uma alteração de, respectivamente, mais ou menos $6 \mathrm{~dB}$.

\subsubsection{Impulso de transmissão}

Se o transdutor não estiver conectado ou acoplado, só é visualizado o impulso de transmissão S. Mesmo com a menor amplificação, ele excede $100 \%$ da altura do monitor. Para distinguir melhor o eco, o respectivo flanco posterior pode ser apresentado como depressão, como se vê na Figura 44. 


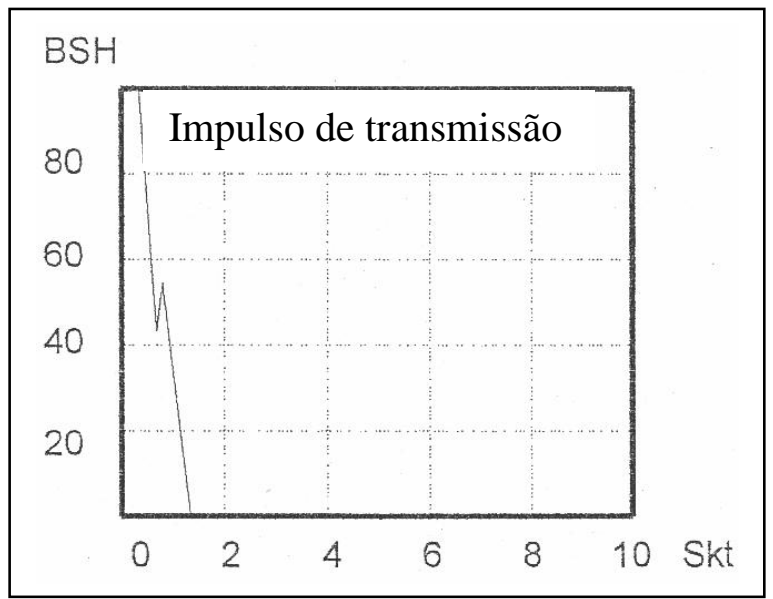

Figura 44 - Representação do impulso de transmissão (ALICH, 2001)

\subsubsection{Imagens de ecos}

Se o transdutor for acoplado a um objeto de controle, surgem imagens adicionais designadas segundo o respectivo tipo de refletor. Os ecos de superfície limite de uma chapa sem descontinuidade, por exemplo, são designados R1, R2, R3. $\mathrm{O}$ ponto base, no qual a linha base passa a flanco anterior da imagem, marca a posição de visualização $T$, na qual a posição da imagem (escala) pode ser lida em aparelhos analógicos de controle ultra-sônico, Figura 45.

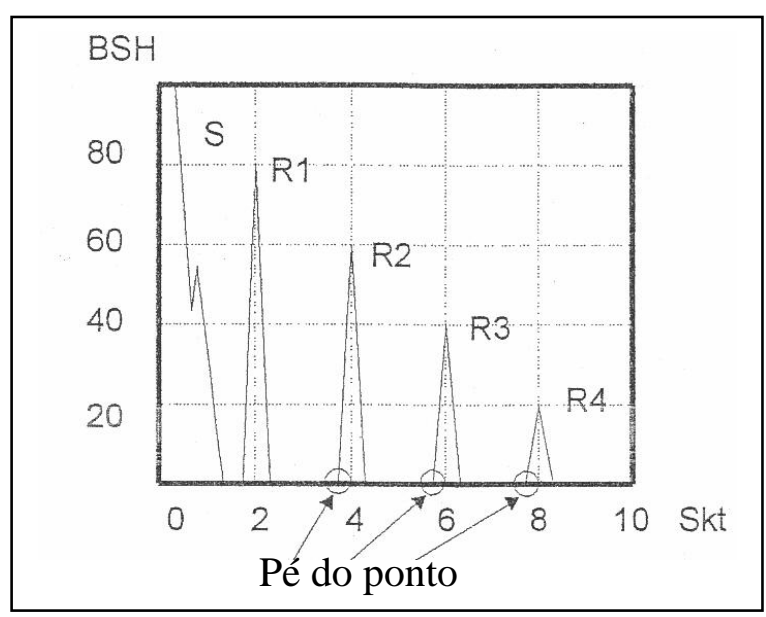

Figura 45 - Imagens de ecos (ALICH, 2001) 


\subsubsection{Seleção do transdutor adequado}

O transdutor é construído com uma carcaça com uma coluna d‘água. A coluna d'água é necessária para reduzir o campo próximo (manter o campo próximo dentro da coluna d'água), além de conseguir o acoplamento ideal entre o transdutor e a peça a ser verificada.

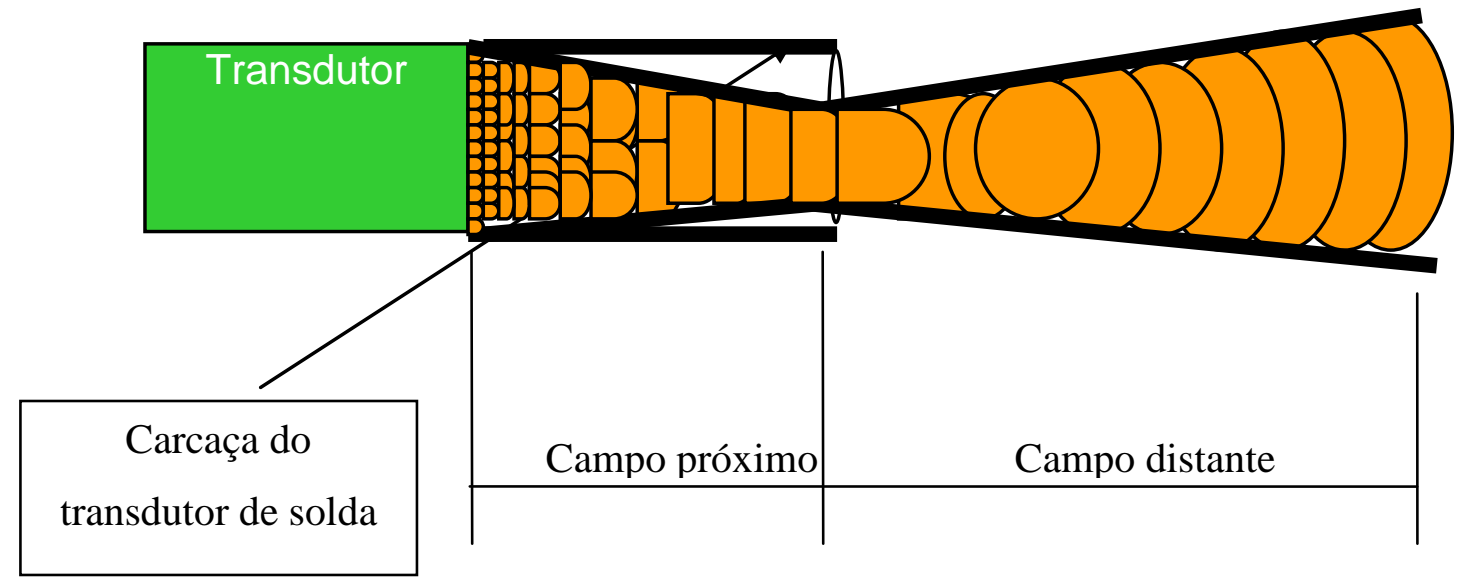

Figura 46 - Perfil do feixe sonoro, ilustrando a aplicação da coluna d'água

Para o controle ultra-sônico de juntas soldadas a ponto são utilizados transdutores especiais, de preferência com uma frequiência que varia de 15 a $20 \mathrm{MHz}$, assim como osciladores de diversos diâmetros, adequados à espessura da parede da chapa mais fina da junta (e assim aos diâmetros das lentilhas). Esses transdutores foram especialmente concebidos para controle ultra-sônico de pontos de solda, conforme a Figura 47. Graças à respectiva membrana plástica flexível, o transdutor adapta-se às diversas formas do ponto de solda, permitindo assim um bom acoplamento ao ponto. A elevada estabilidade do oscilador garante uma excelente resolução do sistema de controle, ou seja, formam-se ecos estreitos com flancos de ecos pronunciados. 


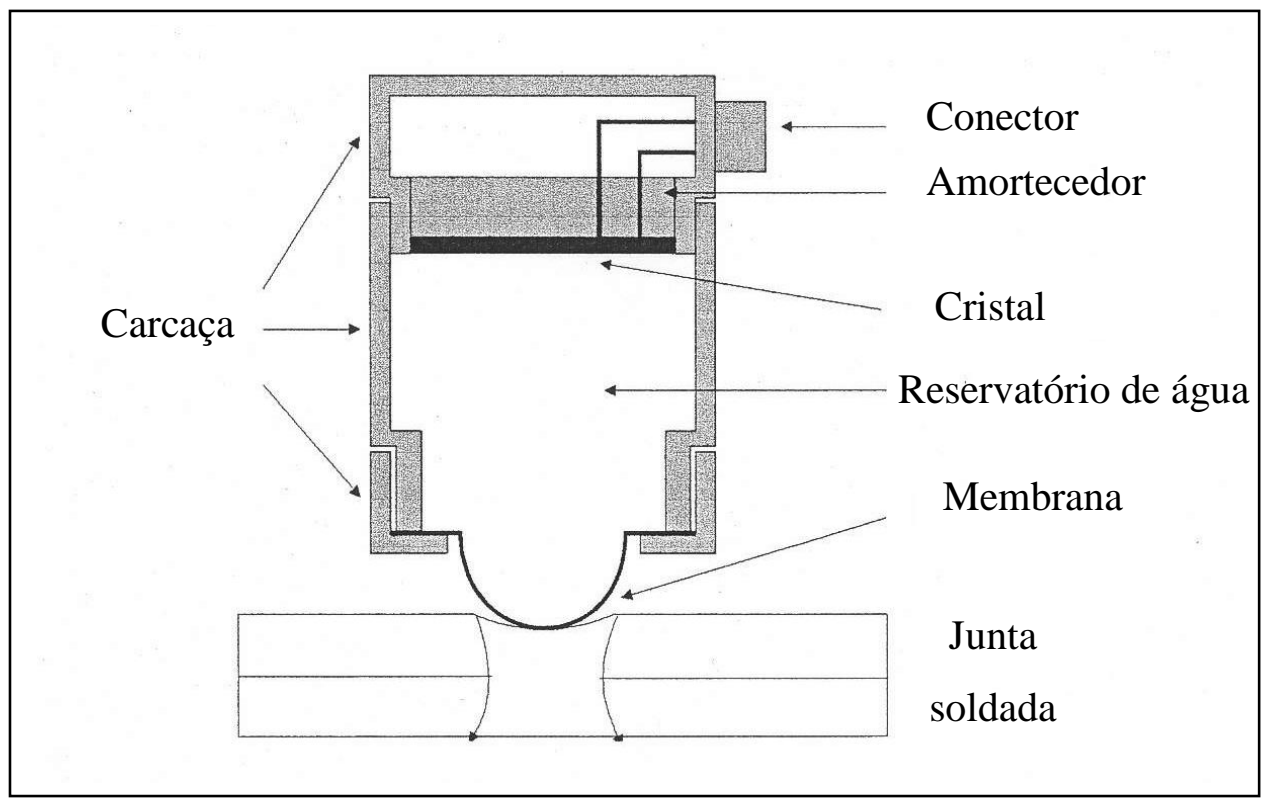

Figura 47 - Estrutura do transdutor especial para controle de solda a ponto (ALICH, 2001)

\subsubsection{Acoplamento do transdutor}

O acoplamento do transdutor à superfície do objeto a ser controlado é essencial para conseguir uma leitura ideal sobre esse objeto. Com prática, dificuldades iniciais de manejo e posicionamento dos transdutores são eliminadas.

A Figura 48 mostra o manejo correto do transdutor. O transdutor é aplicado um pouco inclinado sobre o ponto de solda, após a inspeção visual desse ponto, para detectar respingos de solda que podem causar a destruição da membrana. A seqüência múltipla de ecos visualizados no monitor do aparelho de controle ultrasônico é criada por meio de um movimento circular ou de inclinação. Eventualmente, um meio acoplante pode ser utilizado para facilitar a transmissão sonora no ponto a ser testado, embora não seja um item mandatório. 


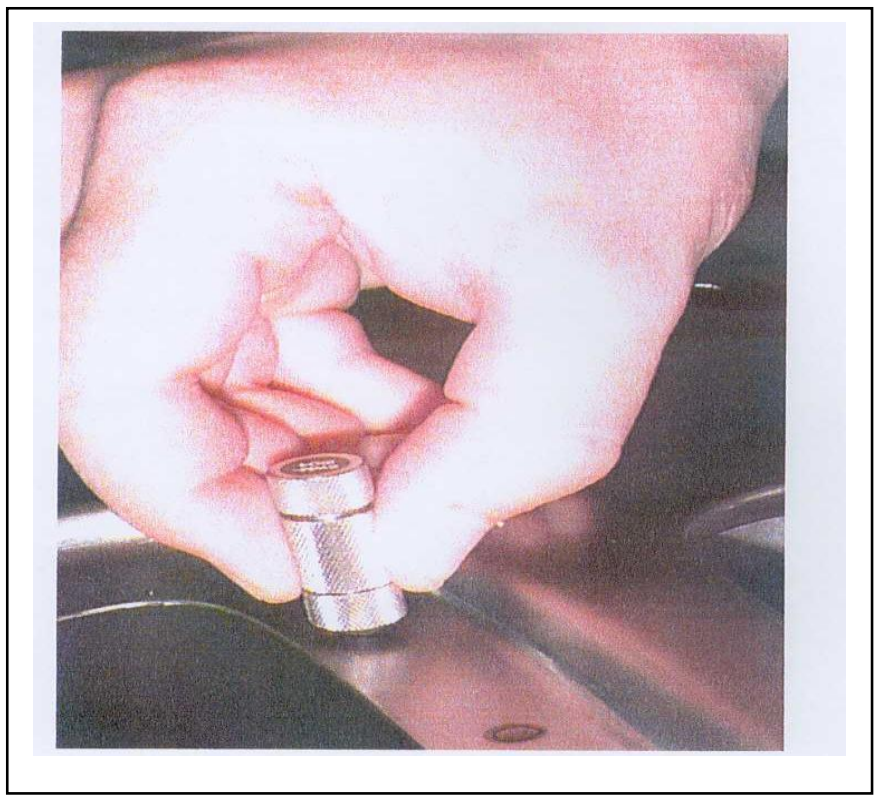

Figura 48 - Aplicação de um transdutor especial

\subsubsection{Avaliação de uma junta}

A interação característica entre falha e ondas ultra-sônicas permite avaliar imagens ultra-sônicas de acordo com uma série de critérios, dentre os quais podem ser destacados a distância entre os ecos, a atenuação do som, altura do eco intermediário, além do número de ecos (Figura 49).

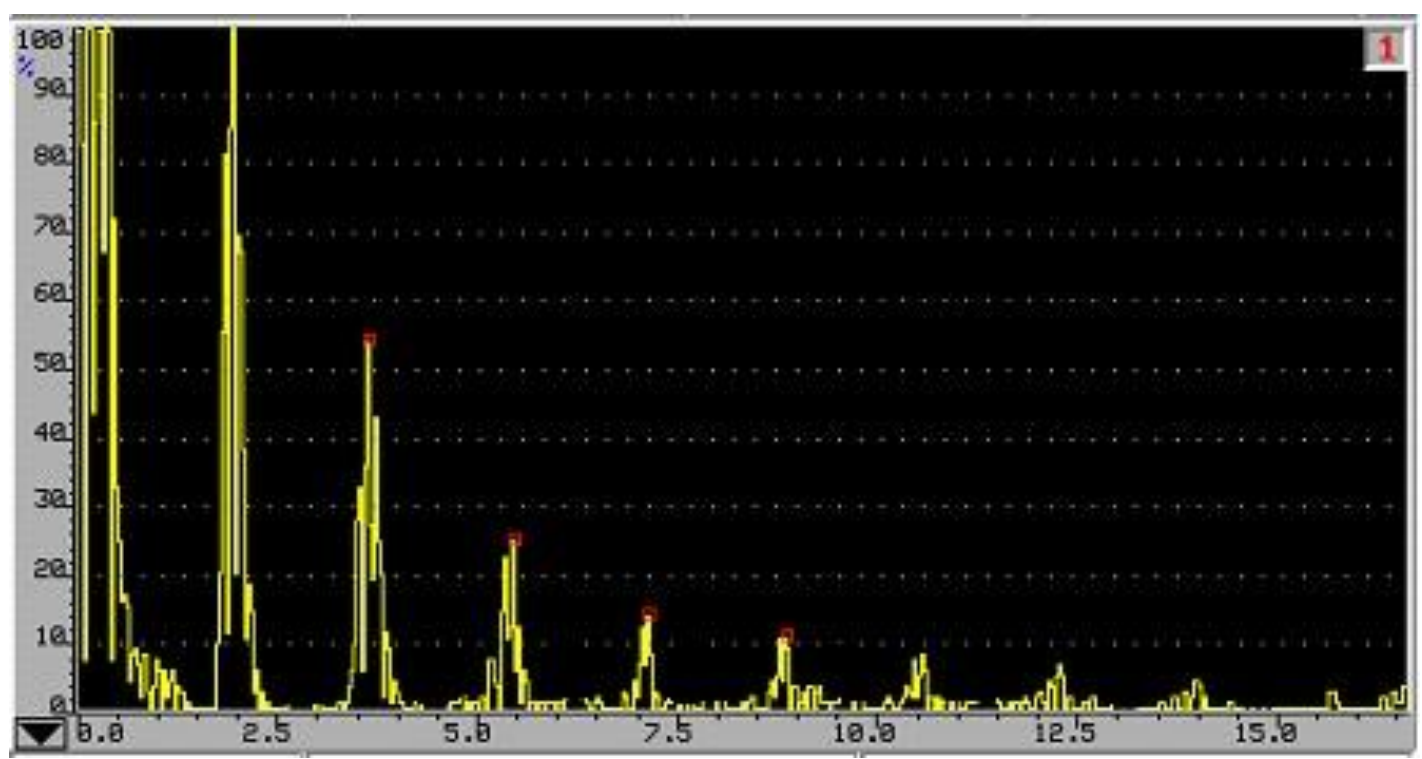

Figura 49 - Imagem de sinal ultra-sônico (A-scan) 
Ao observar um ponto de solda em corte, Figura 50, podem-se verificar claramente as características das ondas sonoras e também a interação entre falhas e ondas ultra-sônicas.

Uma grande parte é dispersa pelo extremo do grão, e não retorna ao transdutor (atenuação do som).

Uma parte da onda sonora é refletida na superfície limite, voltando a ser recebida pelo transdutor.

Numa falha (por exemplo, um poro ou área não soldada) num ponto de solda, parte das ondas sonoras é refletida para o transdutor. No monitor do aparelho de controle ultra-sônico formam-se ecos da superfície limite, pois o tempo de propagação entre a falha e o transdutor é inferior ao tempo de propagação entre a superfície limite e o transdutor. O som é refletido com intensidade diferente conforme o tamanho, a forma e a posição da falha.

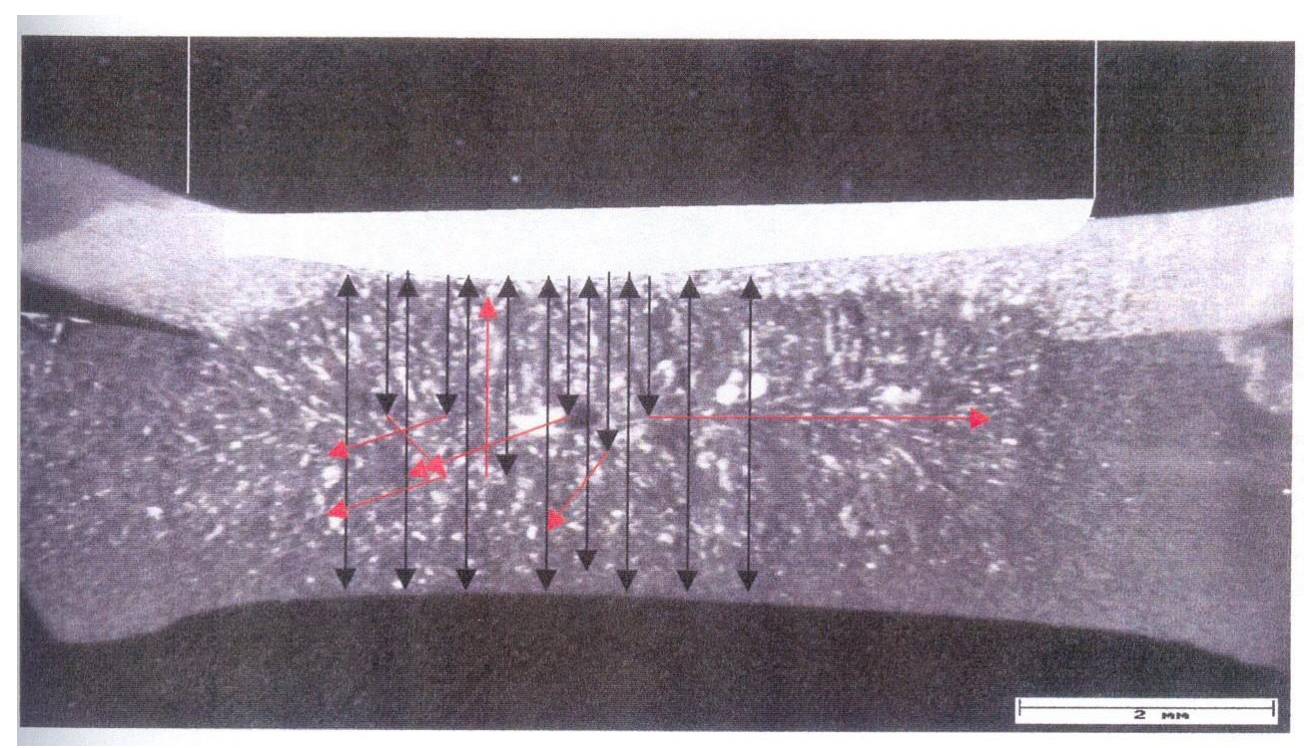

Figura 50 - Distância sonoras num ponto de solda (ALICH, 2001) 


\subsection{Correlação e interpretação dos sinais apresentados no equipamento a-scan $X$ principais defeitos encontrados na solda por resistência a ponto}

A avaliação de um ponto de solda através do ultra-som envolve diversos parâmetros que devem ser considerados, e divergem de uma empresa ou aplicação para outra, como pode-se perceber nas referências citadas no capítulo 2 . O objetivo deste capítulo será então demonstrar como é possível fazer a distinção entre os principais defeitos listados no capítulo 3, sem levar em consideração se os mesmos podem ser ou não objetos de reprovação, tema que será mais bem explorado no experimento relatado no capítulo 7 .

Conforme demonstrado no item anterior, a interpretação da qualidade dos pontos de solda analisados pela técnica de ultra-som dependerá da avaliação das principais características dos sinais, conforme veremos a seguir.

\subsubsection{Ponto em ordem}

A lentilha de solda ideal, conforme ilustrada no capítulo 2 apresenta a-scan característico, conforme ilustrado na Figura 51. É definido por uma sequiência de ecos múltiplos da espessura da união, sem ecos intermediários e com atenuação sonora uniforme, resultado provocado pela formação da estrutura bainítica no caso de aços baixo carbono na região fundida, propiciando uma grande atenuação. Para junções de chapas na faixa entre 0,8 a 2,0 mm (predominância na indústria automotiva), são esperados de 5 a 8 ecos múltiplos até a atenuação completa do pulso inicial. 


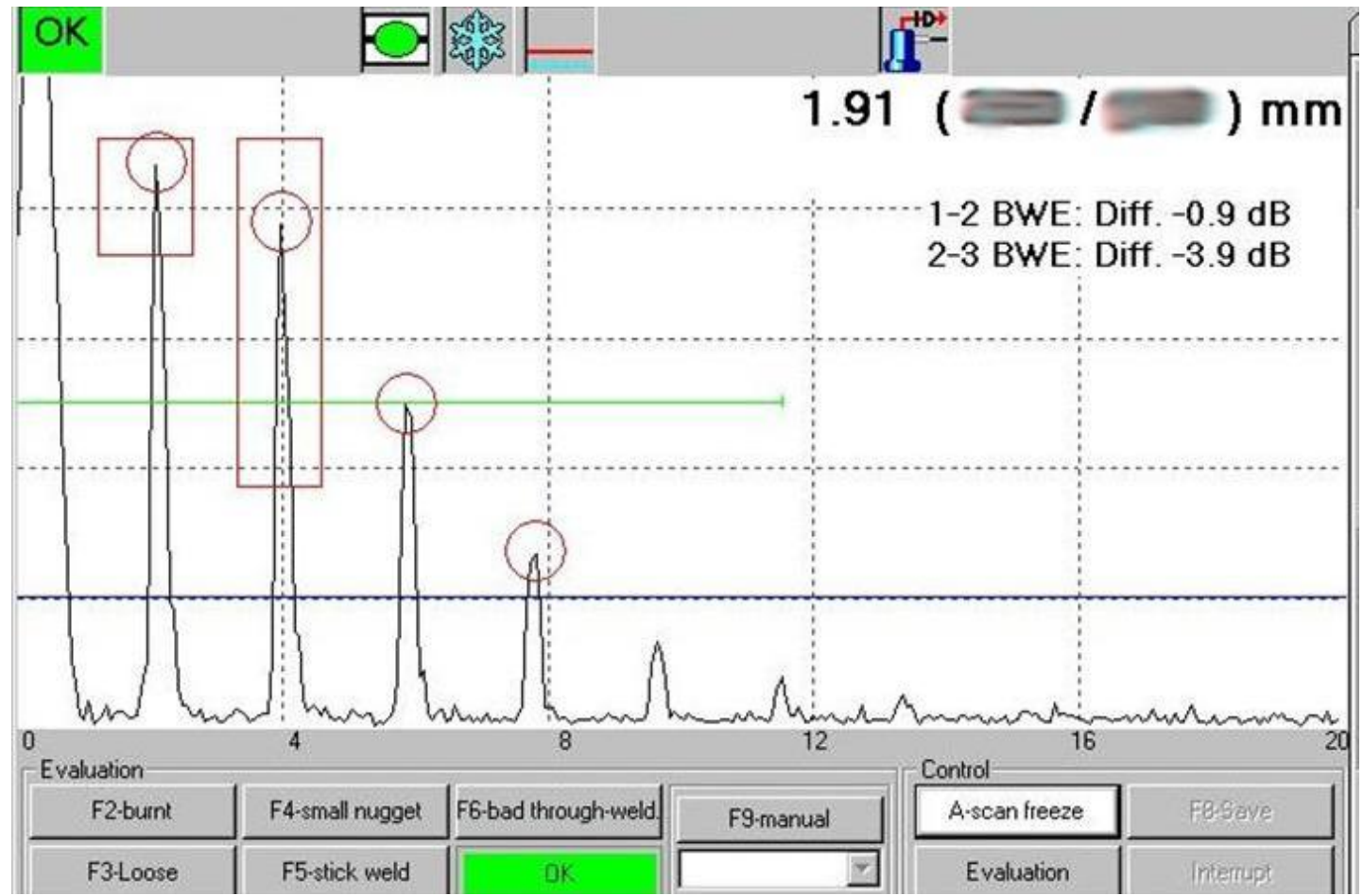

Figura 51 - Imagem ultra-sônica representando ponto em ordem

Outro fator a ser avaliado neste caso é a redução da espessura da junta após o processo de solda, conhecido por indentação, parâmetro que não deve ultrapassar $20 \%$ (DaimlerChrysler, 1999) a $30 \%$ (GM, 2006)

\subsubsection{Ponto solto (Sem fusão, Solda fria)}

Devido à total ausência de uma lentilha de solda fundida, o a-scan característico desta junção é composto de uma série de ecos múltiplos, com a espessura de apenas uma das chapas da junção. 


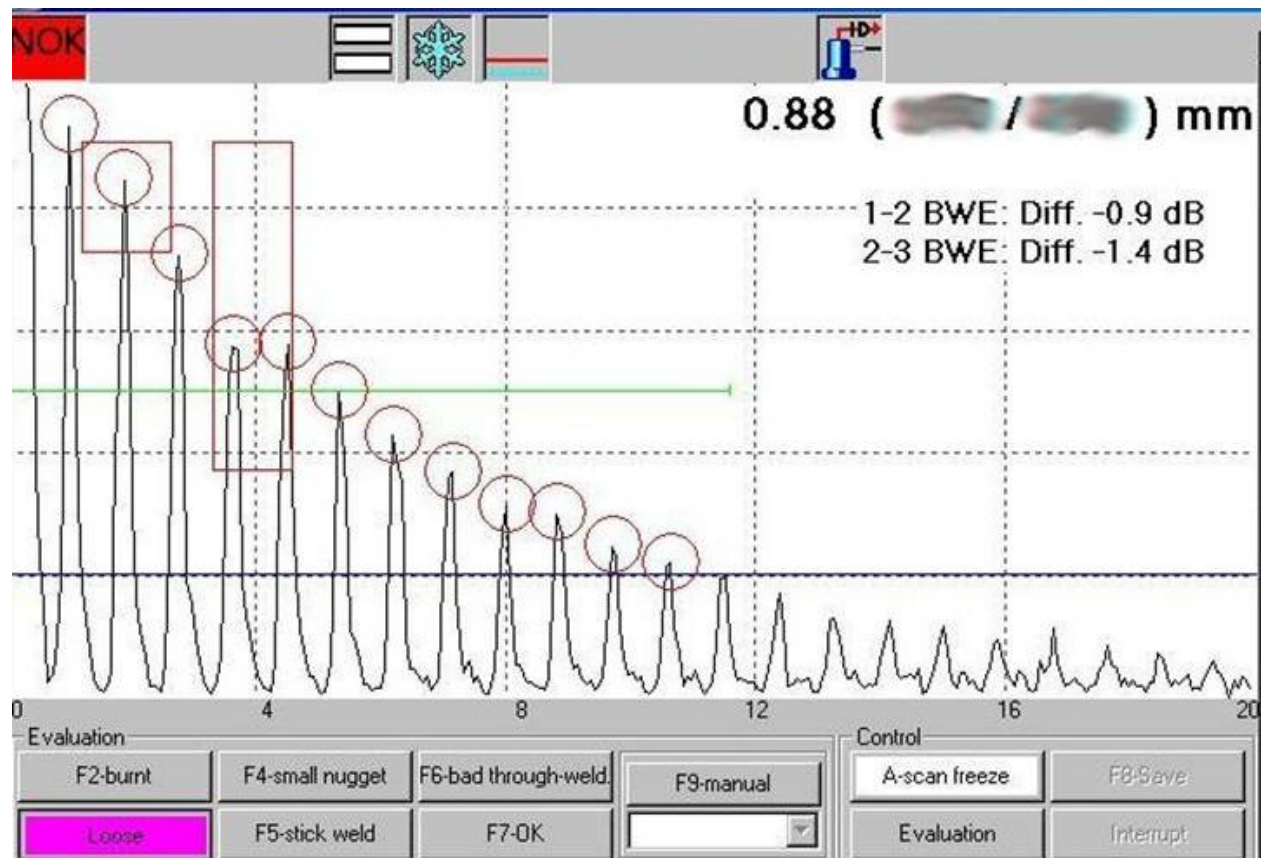

Figura 52 - Imagem ultra-sônica representando a medição de uma única chapa

A quantidade de ecos elevada ocorre principalmente devido ao fato de neste caso não existir região termicamente afetada na chapa, permitindo assim a propagação da onda sonora no material durante um tempo maior, até sua total atenuação.

\subsubsection{Ponto colado}

Conforme citado no capítulo 3, a dificuldade de detecção deste defeito é maior que a da solda fria, pois já existem pontos com início de fusão, o que pode gerar interpretações erradas, principalmente neste ensaio.

Desta forma, os parâmetros a serem considerados são a velocidade de atenuação da onda, medido no equipamento pela quantidade de ecos presentes na tela; A altura dos ecos na tela e a sua taxa de atenuação, medida em $\mathrm{dB} / \mathrm{mm}$ e a espessura da união, que quando não apresenta valores de indentação maiores que 5\% podem indicar um ponto colado. Na Figura 53, é possível ilustrar estes parâmetros, bem como perceber que esta é uma condição limite da técnica, pois existe grande dificuldade em diferenciar os sinais. 


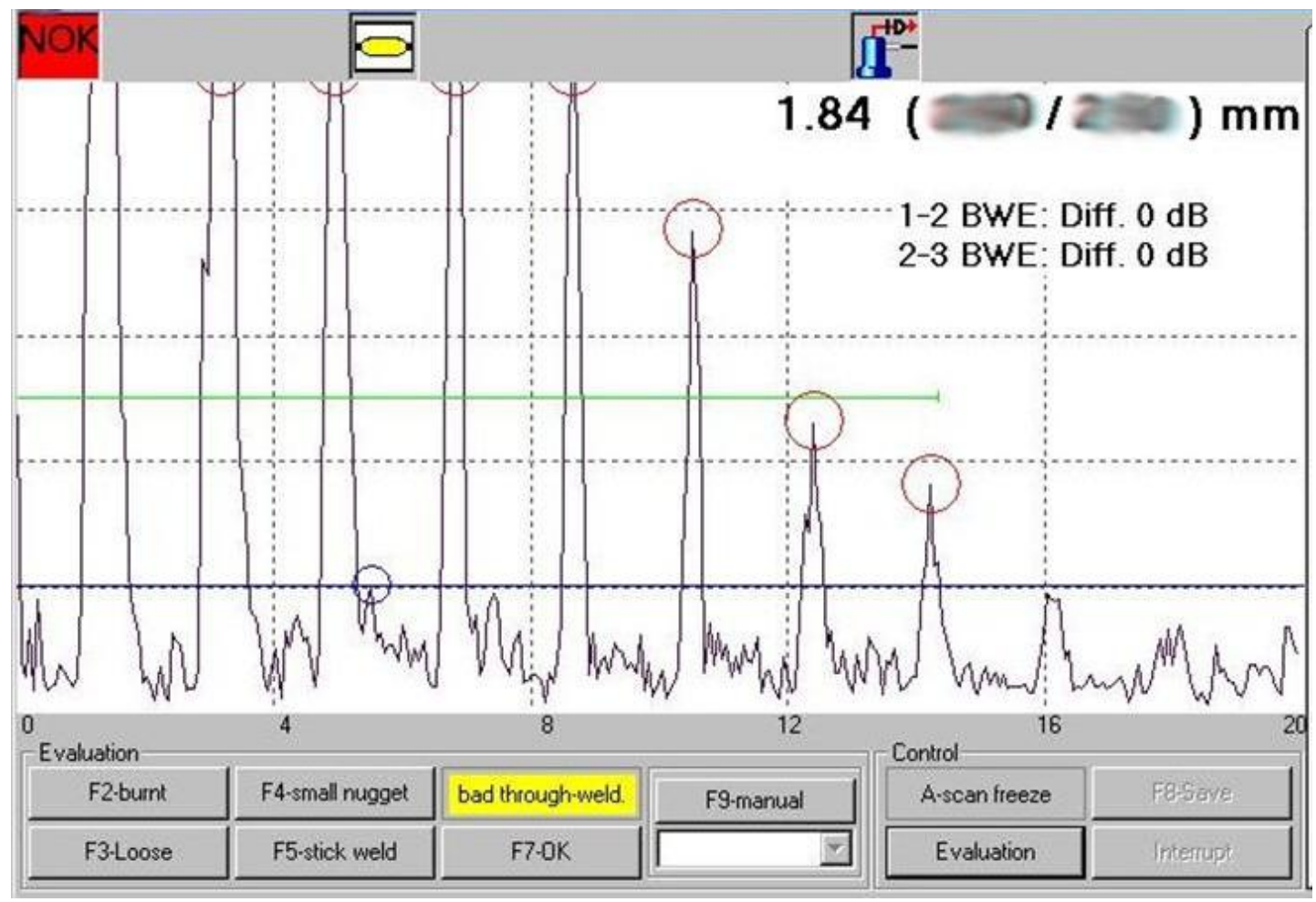

Figura 53: Imagem ultra-sônica representando a medição de um ponto colado.

\subsubsection{Lentilha pequena / Descontinuidade interna (Falha no ponto)}

A identificação e detecção da lentilha pequena, ou com tamanho abaixo do especificado no ensaio com ultra-som com transdutor de elemento único apresenta resultado semelhante à identificação de uma descontinuidade ou falha interna no ponto de solda, e deve ser precedida de uma análise mais criteriosa neste sentido, uma vez que os transdutores possuem um diâmetro fixo de feixe sonoro, ou seja, há a necessidade da utilização do transdutor adequado ao diâmetro do ponto esperado, conforme citado no capítulo 2. Sendo assim, nesta técnica não é possível avaliar quantitativamente o diâmetro da lentilha, mas apenas estimá-lo, identificando se o mesmo está menor que o limite do diâmetro do transdutor selecionado, num padrão semelhante ao mostrado na Figura 54. O feixe sonoro atinge as bordas externas do ponto, que refletem ecos intermediários da espessura de uma única chapa. 


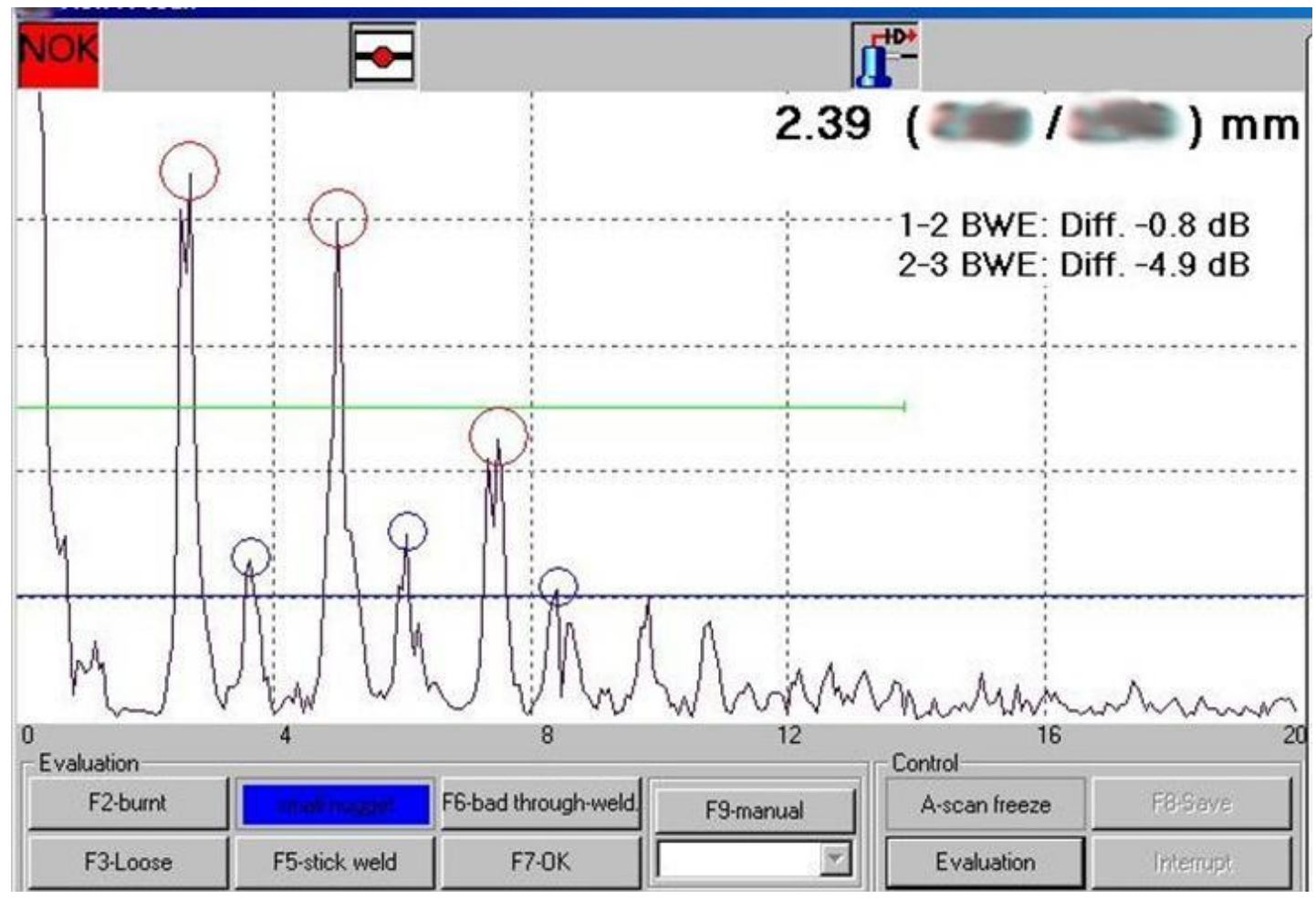

Figura 54: Imagem ultra-sônica representando indicações de eco intermediárias na junta soldada, características de uma lentilha pequena ou descontinuidade interna no ponto

Uma vez assegurada a condição de atendimento do diâmetro correto do ponto, uma indicação de eco intermediário pode indicar uma descontinuidade interna ao ponto de solda. Descontinuidades internas na região fundida do ponto podem ser originadas por diversos fatores, e neste caso a detecção acontece pela reflexão direta desta descontinuidade, sendo apresentada na tela como um eco intermediário, posicionado entre os ecos principais de espessura da junção. Este tipo de defeito, ao contrário dos anteriores, não pode ser detectado através do ensaio de destacamento, conforme detalhado nos capítulos a seguir, sendo a forma de detecção mais indicada os ensaios não destrutivos.

\subsubsection{Excessiva indentação (Ponto queimado)}

Devido a suas características, onde a região fundida atinge toda a extensão do ponto e ao intenso aquecimento durante a sua produção, a morfologia do ponto queimado apresenta granulação grosseira, o que facilita a atenuação sonora, fazendo 
com que a principal característica deste ponto, conforme mostrado na Figura 55 é a quantidade reduzida de ecos, geralmente limitada a uma única reflexão, além de um aumento da indentação, embora esta última característica não esteja presente em todos os casos.

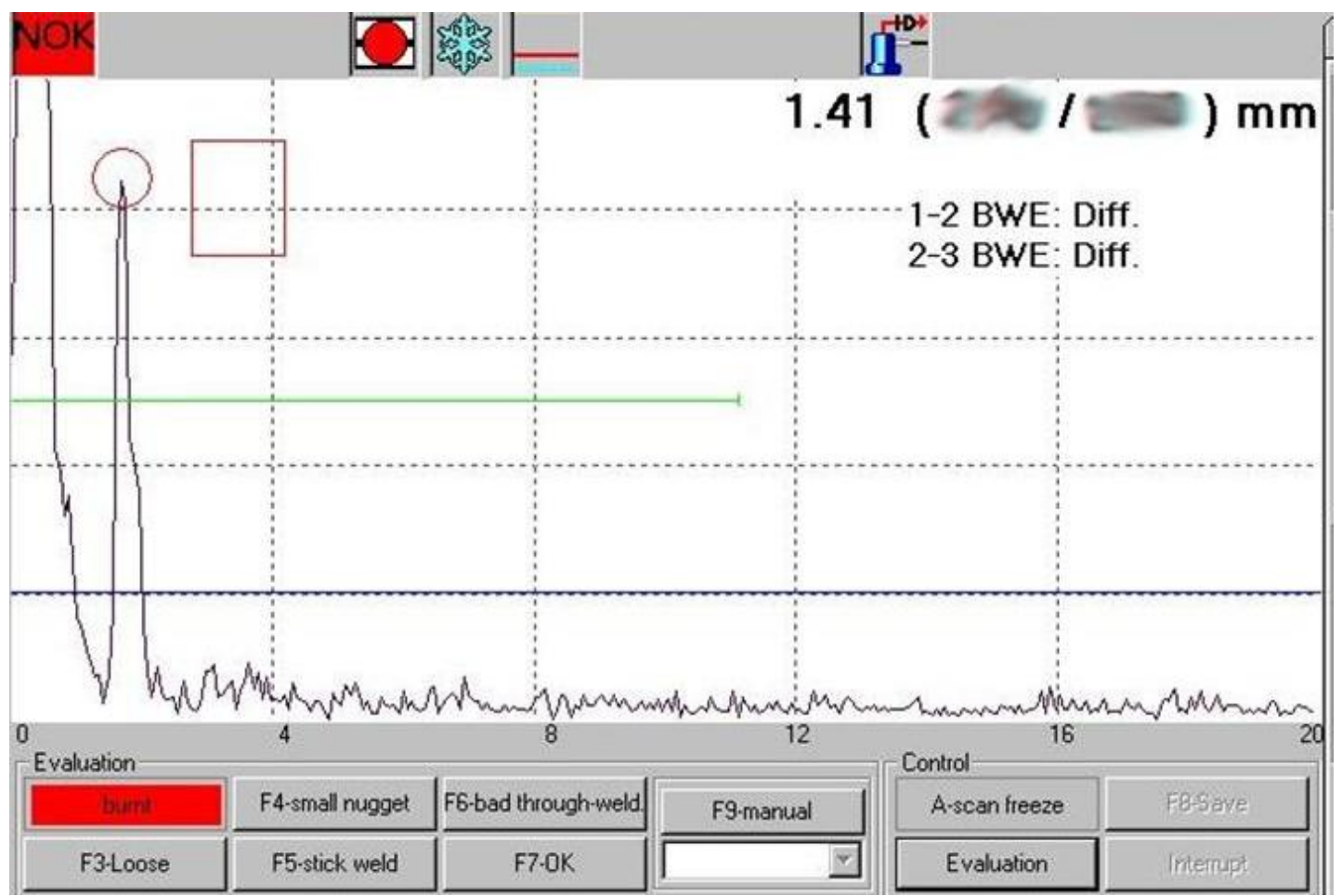

Figura 55: Imagem ultra-sônica representando indicações de eco característica de um ponto queimado

As demais características da falha apresentadas no Capítulo 2, como trincas superficiais e depósito de material do eletrodo não podem ser diretamente detectadas no ensaio, mas o ultra-som é a técnica que pode mesmo de maneira indireta identificar este tipo de falha. 


\subsection{Técnica de ensaio utilizando o transdutor matricial (B- scan)}

A técnica de ultra-som utilizando o transdutor matricial (MAEV, 2000) pode ser considerada o estado da arte na tecnologia de inspeção por ultra-som na solda por resistência a ponto. Os equipamentos utilizados nesta técnica não apresentam diferenças significativas em relação àqueles mostrados no capítulo 6.11, sendo então as principais diferenças entre as técnicas o transdutor utilizado e a evolução do software, que passa a utilizar algoritmos utilizados anteriormente em microscópios acústicos, realmente simplificando o manuseio e interpretação dos operadores.

\subsubsection{Transdutor matricial}

De mesmo princípio ao apresentado no capítulo 5, o transdutor matricial utiliza-se da técnica de impulso-eco, com o diferencial da utilização de múltiplos cristais.

DENISOV (2004) define a aplicação da medição por ultra-som 2-D como um novo conceito no ensaio de solda por resistência a ponto, que ao invés da varredura mecânica, o sinal percorre uma matriz de pequenos transdutores. Cada elemento desta matriz, mostrada na Figura 56, envia e recebe sinais independentemente coletando assim a informação estrutural da amostra detectada por aquele elemento específico. 


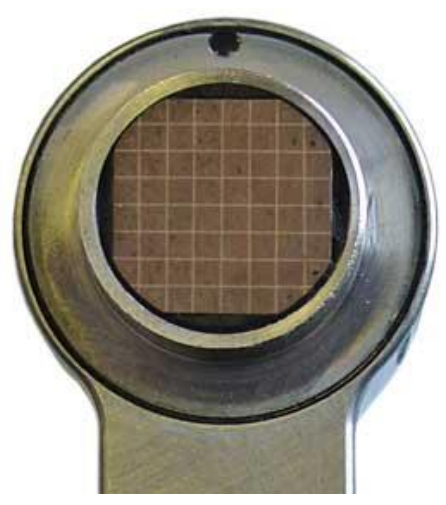

Figura 56: Imagem ampliada de transdutor matricial (DENISOV, 2004)

Através da resposta combinada de todos estes elementos (MAEV,2000), é possível construir uma imagem ultra-sônica da estrutura interna do ponto de solda em uma determinada profundidade (uma matriz com 52 elementos, utilizada nesta técnica, gasta aproximadamente de 0.3 a 0.7 segundos para visualizar uma área de $10 \times 10 \mathrm{~mm}$ ). A resolução da varredura $2 \mathrm{D}$ é geralmente limitada pelo tamanho dos elementos.

\subsubsection{Geração de imagens e interpretação dos resultados}

Inicialmente a captação e análise de imagens parte do mesmo princípio adotado na técnica a-scan, pois cada um dos elementos do transdutor matricial é disparado individualmente, produzindo seu eco característico. A apresentação da onda sonora é feita no modo absoluto.

Como ilustrado na Figura 57, quando são inspecionadas solda a ponto, a presença na região central da junção pode indicar que existe uma separação entre as chapas, correspondendo a uma área não soldada (A). Se a solda existe, não existem reflexões internas, e apenas a reflexão da superfície limite da chapa inferior ao lado inspecionado é detectada (C). Analogamente, se o elemento disparado cobrir uma área que está parcialmente soldada, o sinal resultante será uma combinação das áreas mostradas em A e C. 


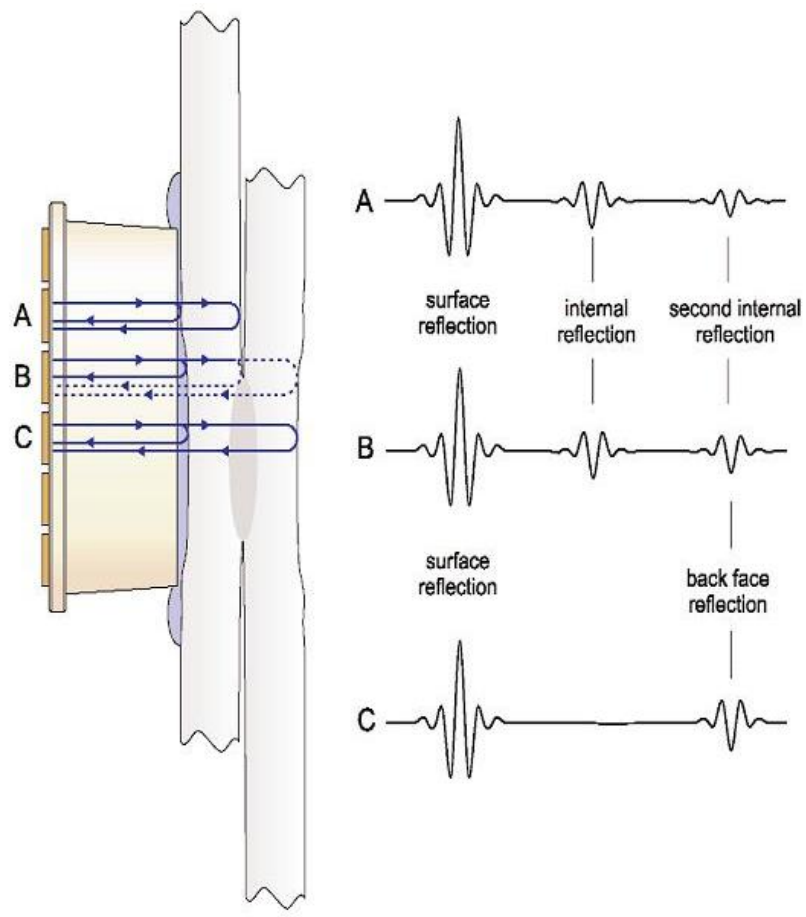

Figura 57: Representação do percurso sonoro dentro da amostra e a representação do sinal correspondente (DENISOV, 2004).

Depois do sinal coletado, o controlador ativa o elemento seguinte, e assim sucessivamente pelos 52 elementos do transdutor (DENISOV, 2002), até que todos os sinais estejam processados.

As amplitudes de sinal registradas nos cristais são utilizadas para construir uma imagem ultra-sônica da região inspecionada. Esta imagem pode ser apresentada sob uma escala de cinza ou com uma codificação por cores através do mapeamento da máxima amplitude de uma escala pré-definida relacionada com o brilho ou a cor de cada pixel formando uma escala de cores da maior amplitude (vermelho) até a menor amplitude (verde). Na Figura 58, a área verde no centro corresponde à região soldada, enquanto que a região vermelha corresponde à área não soldada. 


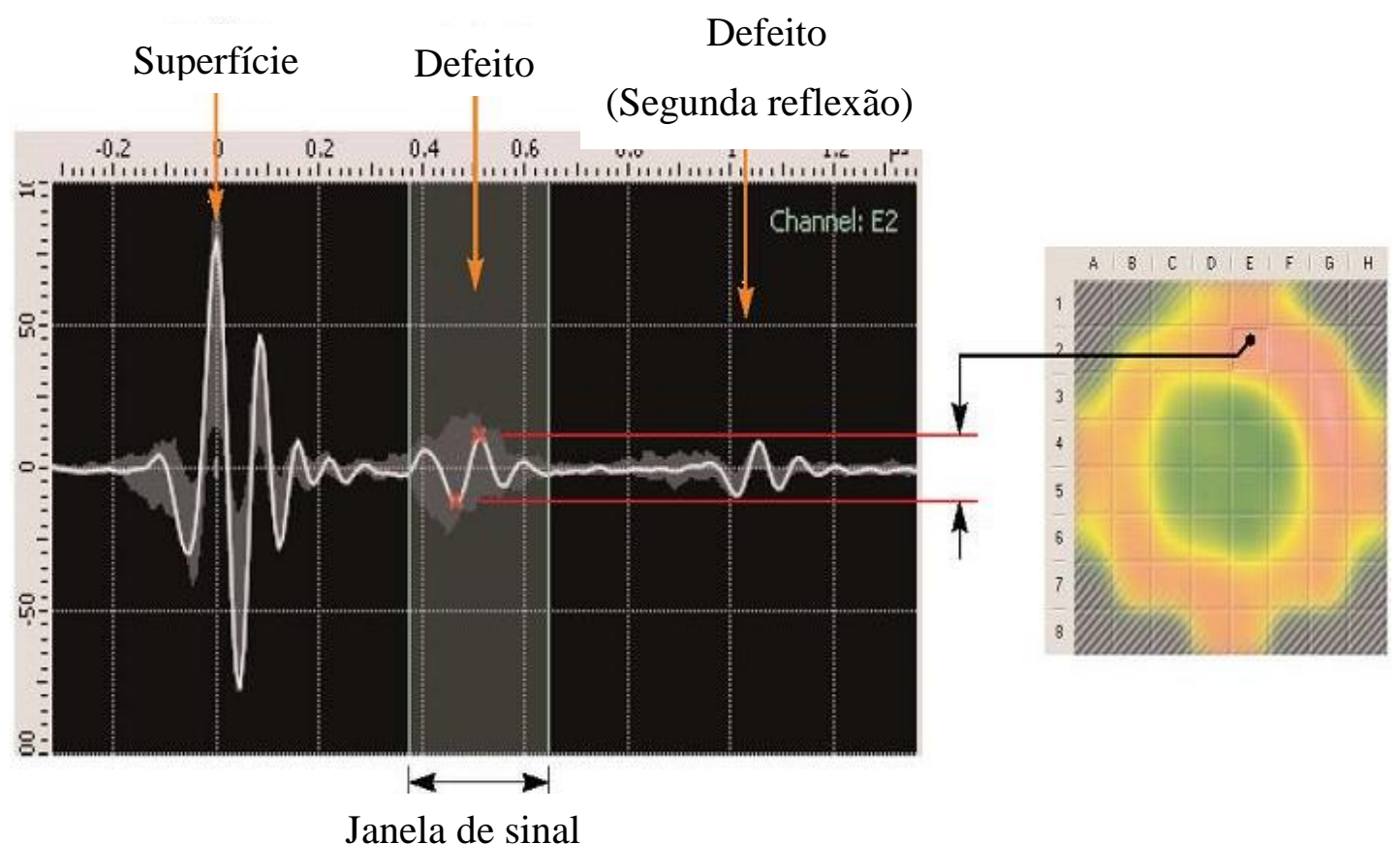

Figura 58: Imagem a-scan e respectiva representação b-scan na tela do equipamento.(DENISOV, 2004).

São utilizados diversos recursos para estabilizar e melhorar a qualidade da imagem apresentada, com o objetivo de facilitar a visualização e interpretação dos operadores.

Esta imagem, em conjunto com uma combinação de algoritmos, permite gerar uma estimativa automática do diâmetro da região fundida, parâmetro considerado o mais importante no controle de qualidade na soldagem por resistência a ponto, como pode ser observado em detalhes na Figura 59, onde é possível verificar a estimação automática do diâmetro da lentilha (A), após a análise dos sinais gerados por cada um dos cristais (B). 


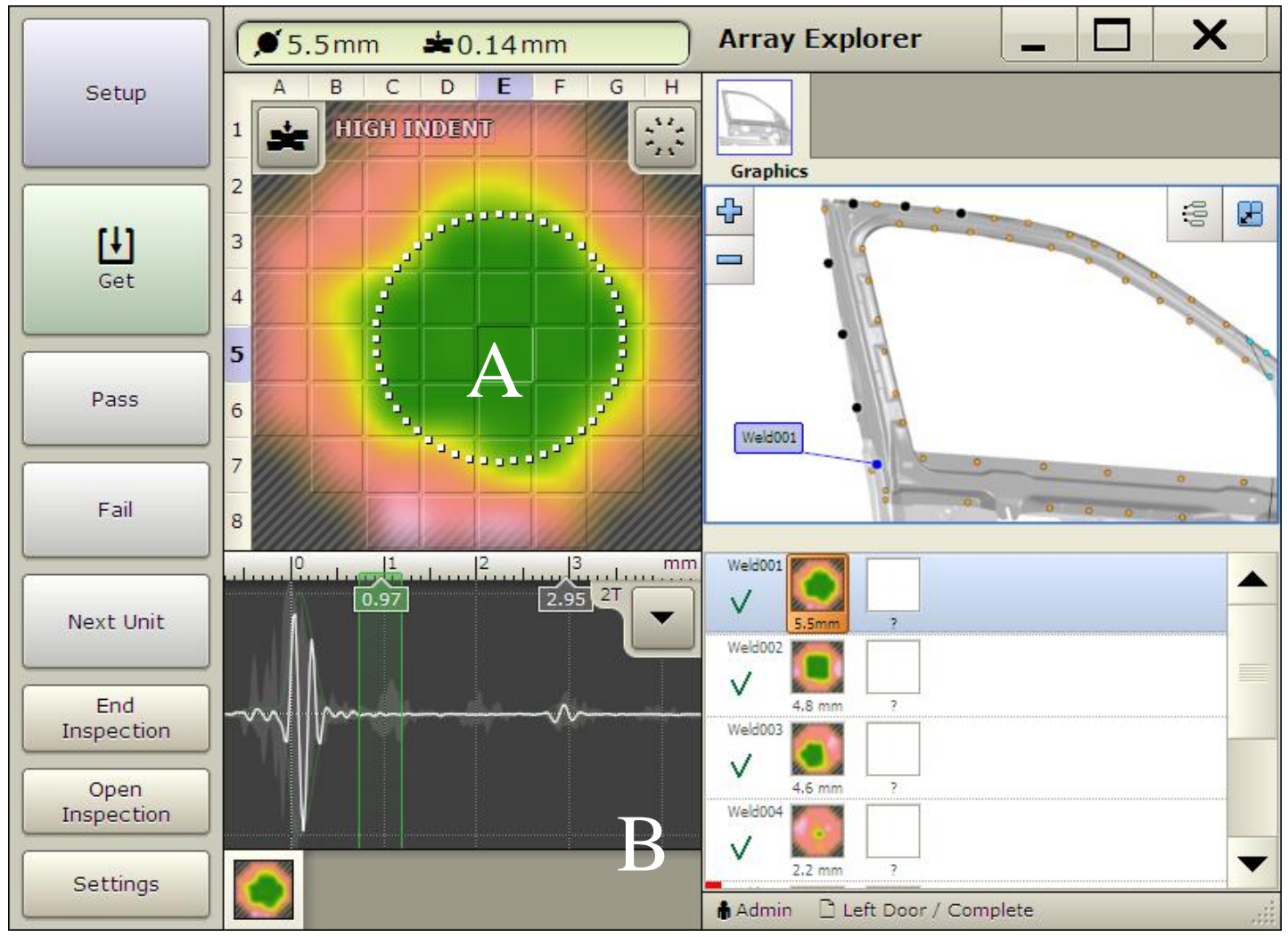

Figura 59: Imagem da tela do equipamento, mostrando a imagem gerada (A), e o respectivo sinal a-scan $(B)$.

Assim sendo, este pode ser considerado o grande diferencial desta técnica quando comparada à técnica do transdutor de simples elemento, pois é possível fazer uma medição direta do diâmetro do ponto de solda a uma determinada profundidade da junta a ser inspecionada. Usualmente o foco da medição será a região compreendida pela interface entre oas duas chapas da junta, como será demonstrado no experimento realizado no capítulo 7.

Da mesma forma observada no a-scan, pequenas variações no posicionamento do transdutor ou geometria do ponto a ser inspecionado podem eventualmente produzir pequenas falhas na geração desta imagem, que podem ser percebidas instantaneamente pelo operador do equipamento.

Pontos de solda que apresentam geometrias diferenciadas da forma circular tem uma estimação do diâmetro prejudicada, pois o algoritmo apresenta dificuldades na detecção. 
O algoritmo que estima automaticamente o diâmetro age em dois estágios: Inicialmente, a posição do centro e o diâmetro do círculo da solda são estimados através de uma transformada de Hough (Illingworth, 1988 apud Denisov, 2004). No segundo passo, a medição do diâmetro do círculo é refinada em coordenadas polares. Este refinamento, como mostra Figura 60, faz com que as medições de diâmetro se tornem bastante precisas.
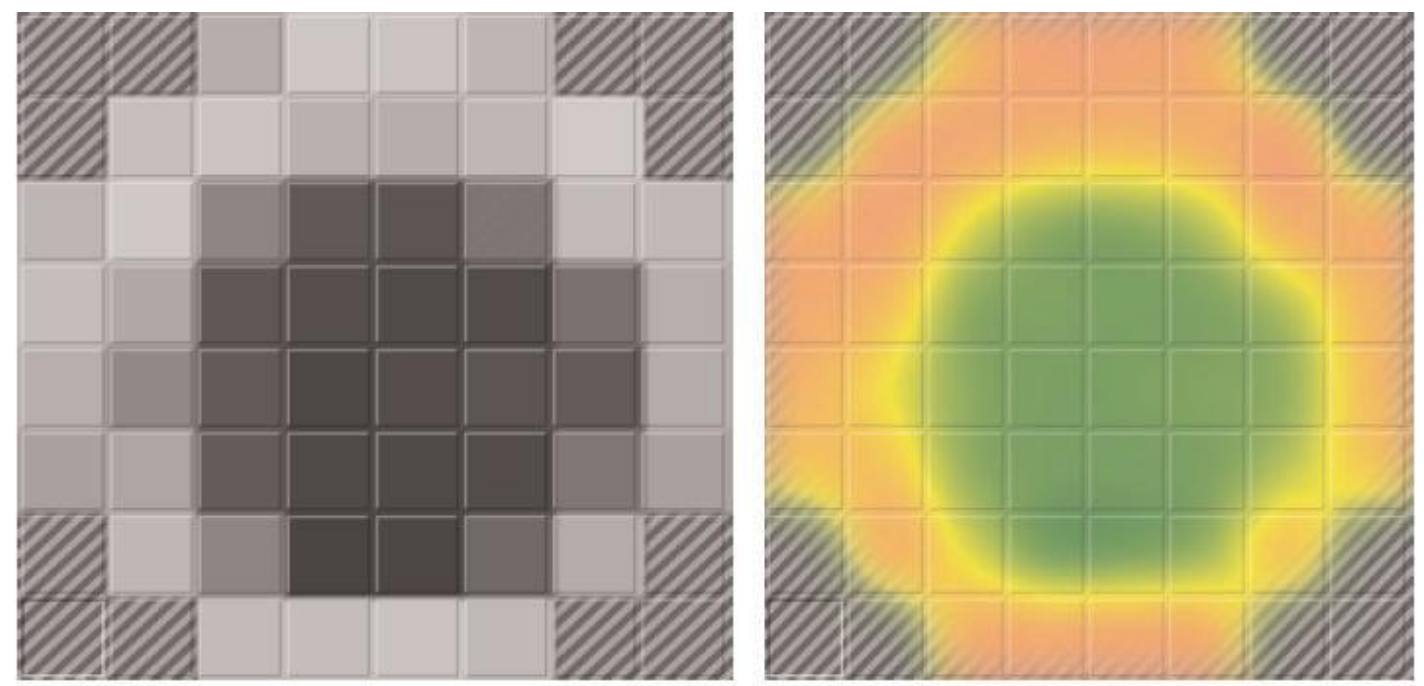

Figura 60: Imagem de uma região soldada, obtida com o transdutor matricial sem interpolação (esquerda), e após interpolação (direita). Cada célula cobre $1 \mathrm{~mm}^{2}$ de área (DENISOV, 2004).

Assim sendo, a correlação das medições efetuadas com esta técnica versus os ensaios de destacamento fica prejudicada, uma vez que podem ser encontradas diferenças de até $20 \%$, especialmente devido à subjetividade do ensaio de destacamento, conforme demonstrado no capítulo 4. Ainda assim, esta forma de avaliação é ainda considerada importante, uma vez que em sua maioria, os procedimentos das grandes empresas estão baseados na medição deste diâmetro.

Assim, a correlação mais precisa deste tipo de ensaio será verificada frente aos ensaios metalográficos e à medição utilizando-se de microscópio acústico, onde os desvios dimensionais não ultrapassam $0,05 \mathrm{~mm}$, mostrando neste caso a maior confiabilidade do equipamento, conforme mostram as figuras 61 a 64. Estes 
resultados, posteriormente comparados aqueles demonstrados no capítulo 7 , não apresentaram correlação tão representativa a esta aqui demonstrada.

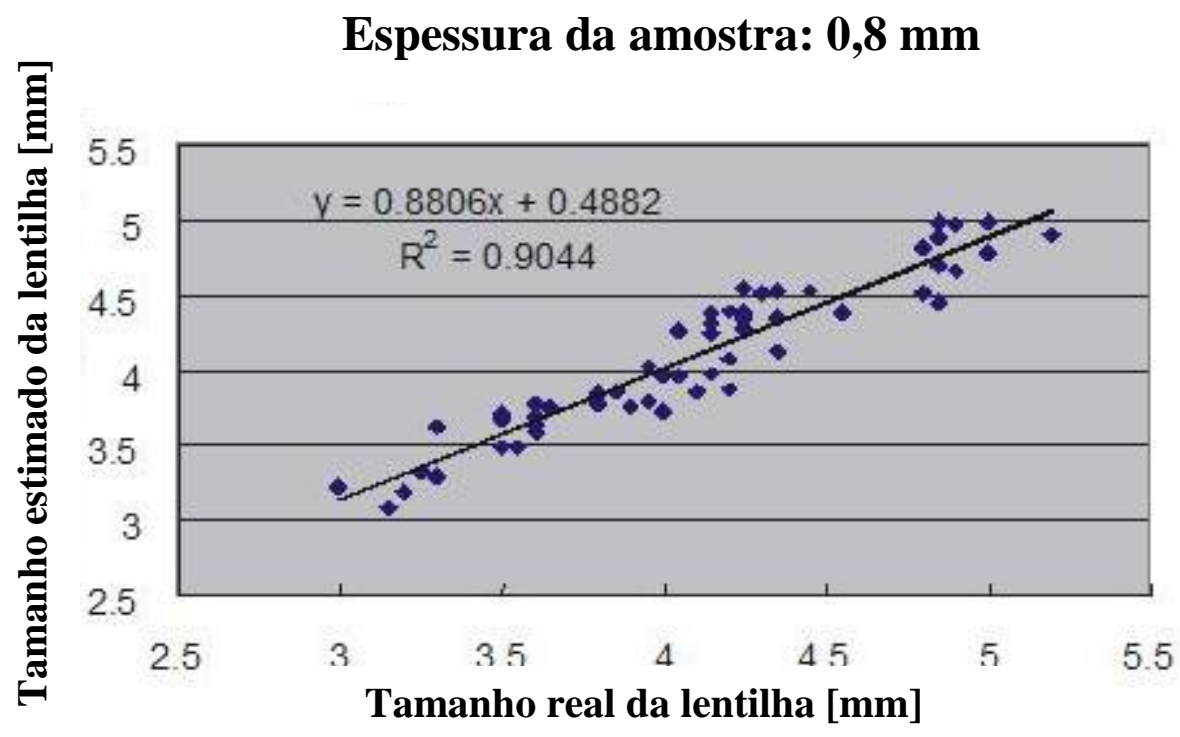

Figura 61: Ensaios de correlação apresentando comparação entre diversos diâmetros de ponto medidos através do RSWA X medição real do ponto através de microscopia (a) $0.8 \mathrm{~mm}$ - (DENISOV, 2004 - modificado).

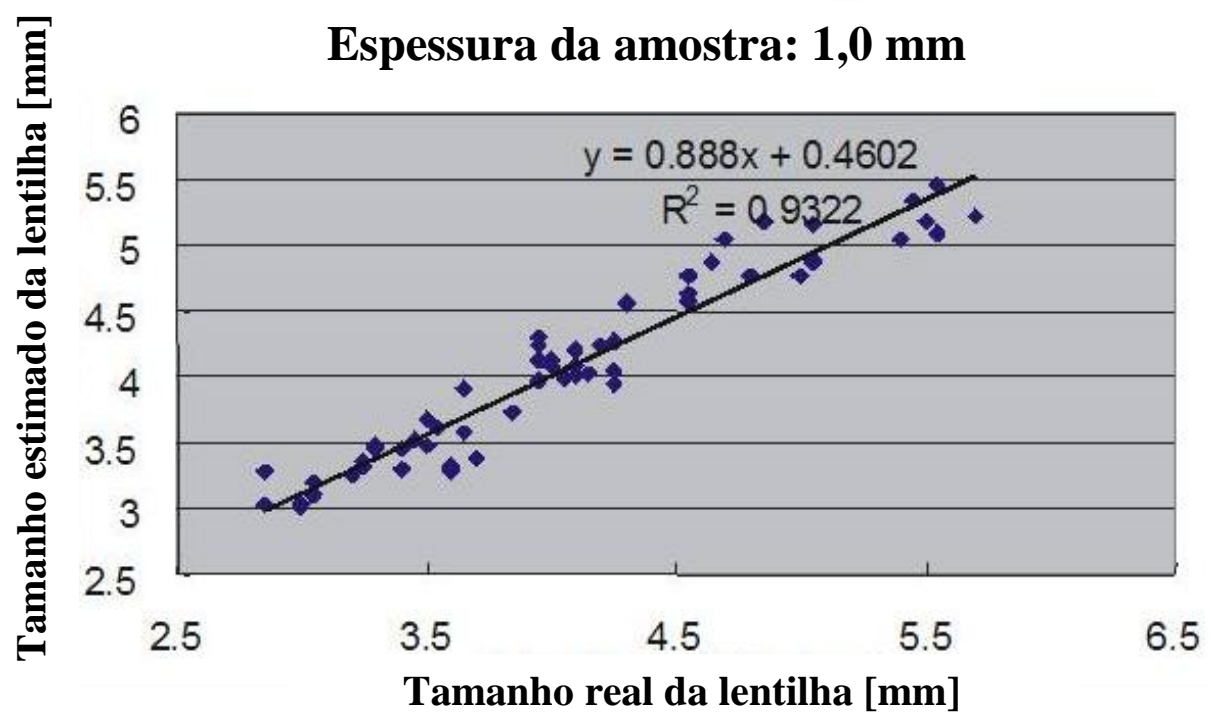

Figura 62: Ensaios de correlação apresentando comparação entre diversos diâmetros de ponto medidos através do RSWA X medição real do ponto através de microscopia - $1.0 \mathrm{~mm}$, (DENISOV, 2004 - modificado). 
Espessura da amostra: $1,2 \mathrm{~mm}$

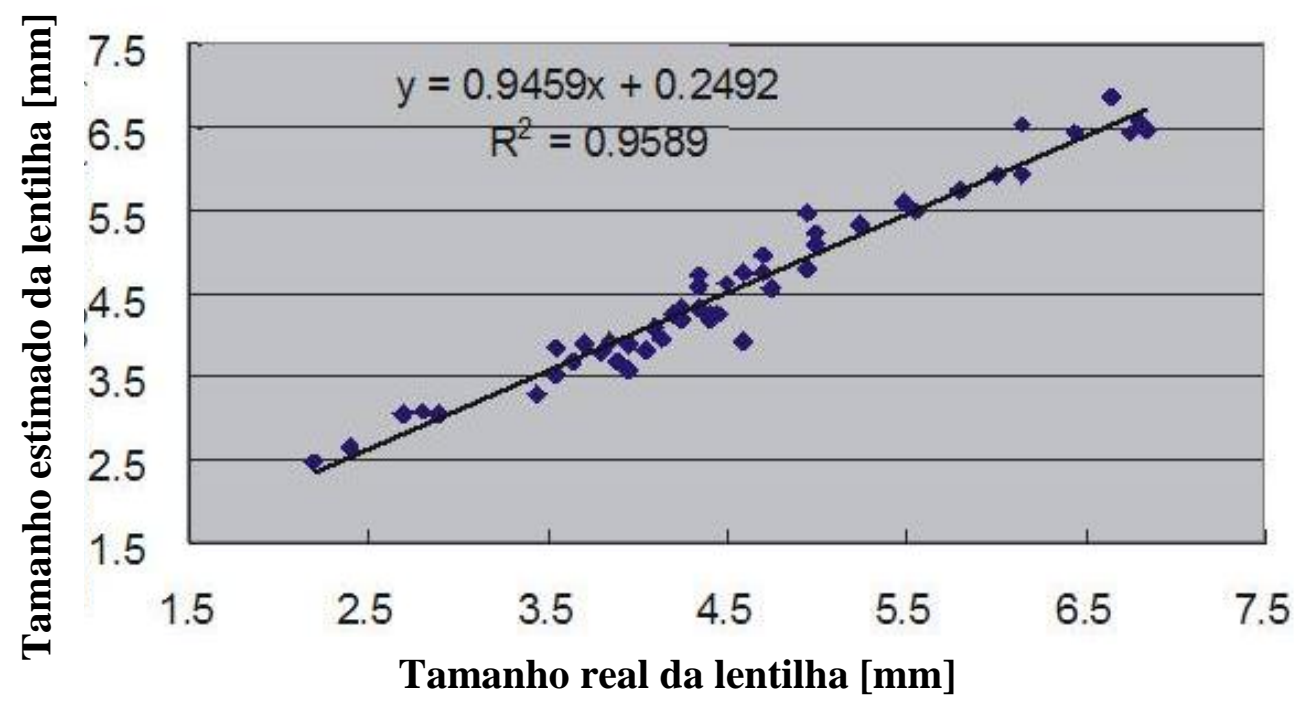

Figura 63: Ensaios de correlação apresentando comparação entre diversos diâmetros de ponto medidos através do RSWA X medição real do ponto através de microscopia (c) $1.2 \mathrm{~mm}$, (DENISOV, 2004 - modificado).

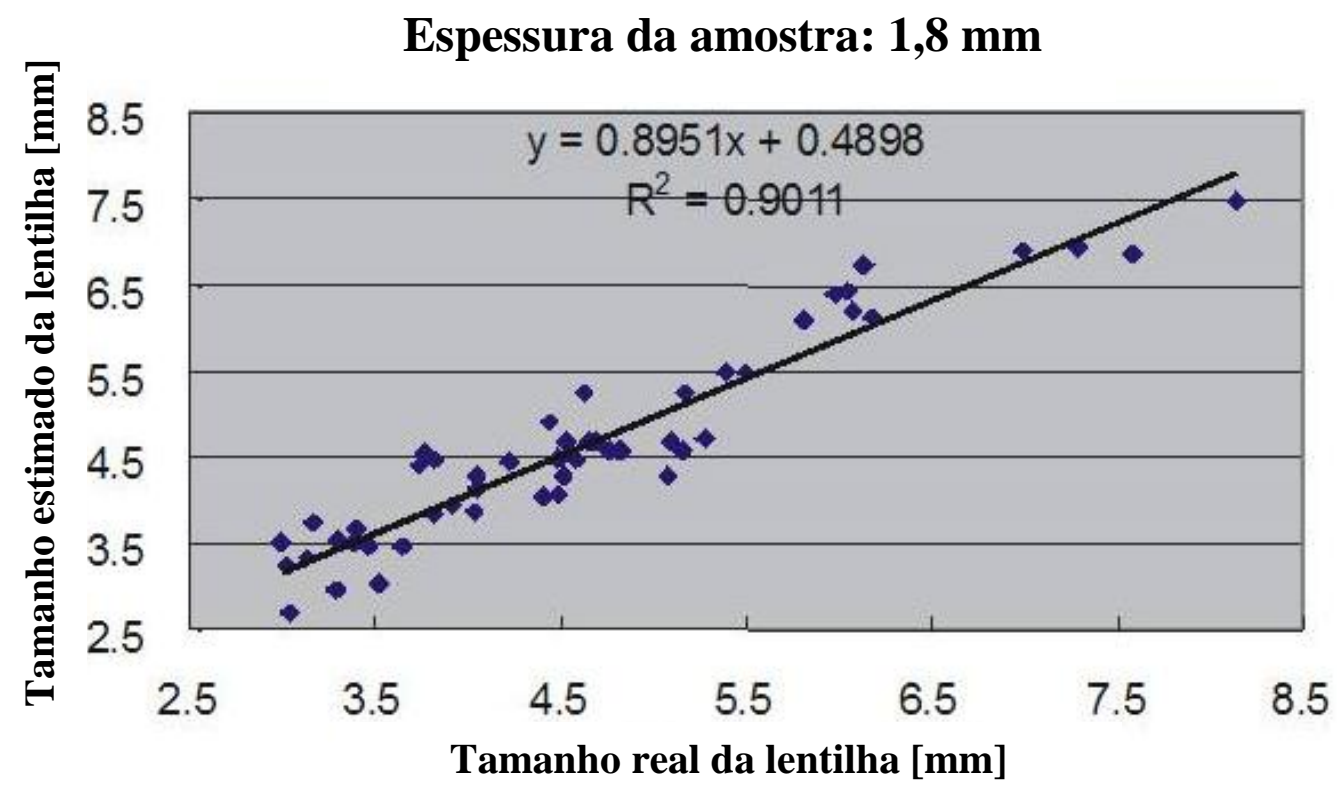

Figura 64: Ensaios de correlação apresentando comparação entre diversos diâmetros de ponto medidos através do RSWA $\mathrm{X}$ medição real do ponto através de microscopia, (d) 1.8 mm (DENISOV, 2004 - modificado). 


\section{PROCEDIMENTO EXPERIMENTAL}

\subsection{Objetivos}

Neste capítulo serão mostrados basicamente dois procedimentos experimentais visando demonstrar a eficiência e confiabilidade dos ensaios de ultrasom, quando comparados aos ensaios metalográficos e ensaios de fadiga e tração.

O primeiro experimento visa determinar o parâmetro para aprovação de uniões de chapas de aço baixo carbono por solda a ponto, através de técnicas de ultra-sonografia, usando como critério de determinação deste parâmetro os resultados de ensaios de fadiga em juntas soldadas por três pontos, com dois diferentes graus de indentações previamente determinados por técnicas de ultra-sonografia (STOCCO, 2003).

O segundo experimento tem por objetivo verificar a correlação entre os ensaios de ultra-som utilizando o transdutor matricial (b-scan), quando comparados ao ensaio de destacamento e aos ensaios metalográficos, visando verificar a efetividade dos resultados apresentados no capítulo 6.

\subsection{Utilização de inspeção por ultra-sonografia para aprovação de uniões por solda a ponto submetidas à fadiga.}

\subsubsection{Materiais e métodos}

A partir de chapas de aço baixo carbono de $1,5 \mathrm{~mm}$ de espessura, com a composição química mostrada na Tabela 7.1 e as propriedades mecânicas nominais mostradas na Tabela 7.2, foi obtido tiras de $50 \mathrm{~mm}$ de largura e $110 \mathrm{~mm}$ de comprimento. Tais tiras foram sobrepostas e unidas por três pontos de solda, gerando as juntas soldadas detalhadas na Figura 65. Vale ainda ressaltar que para este estudo as chapas utilizadas não possuem qualquer tipo de proteção superficial. 
Tabela 7.1: Composição química nominal do aço em estudo (\% massa).

\begin{tabular}{|cccccc|}
\hline Elemento & $\mathrm{C}$ & $\mathrm{Mn}$ & $\mathrm{P}$ & $\mathrm{S}$ & $\mathrm{Al}$ \\
\% massa & 0,08 & 0,45 & 0,03 & 0,03 & 0,02 \\
\hline
\end{tabular}

Tabela 7.2: Propriedades mecânicas do aço em estudo.

\begin{tabular}{|cc|}
\hline Módulo de elasticidade $(\mathrm{GPa})$ & 207 \\
\hline Limite de escoamento $(\mathrm{MPa})$ & 195 \\
\hline Limite de resistência $(\mathrm{MPa})$ & 304 \\
Alongamento total em 50 mm (\%) & 49,2 \\
Dureza (HV) & 100 \\
\hline
\end{tabular}
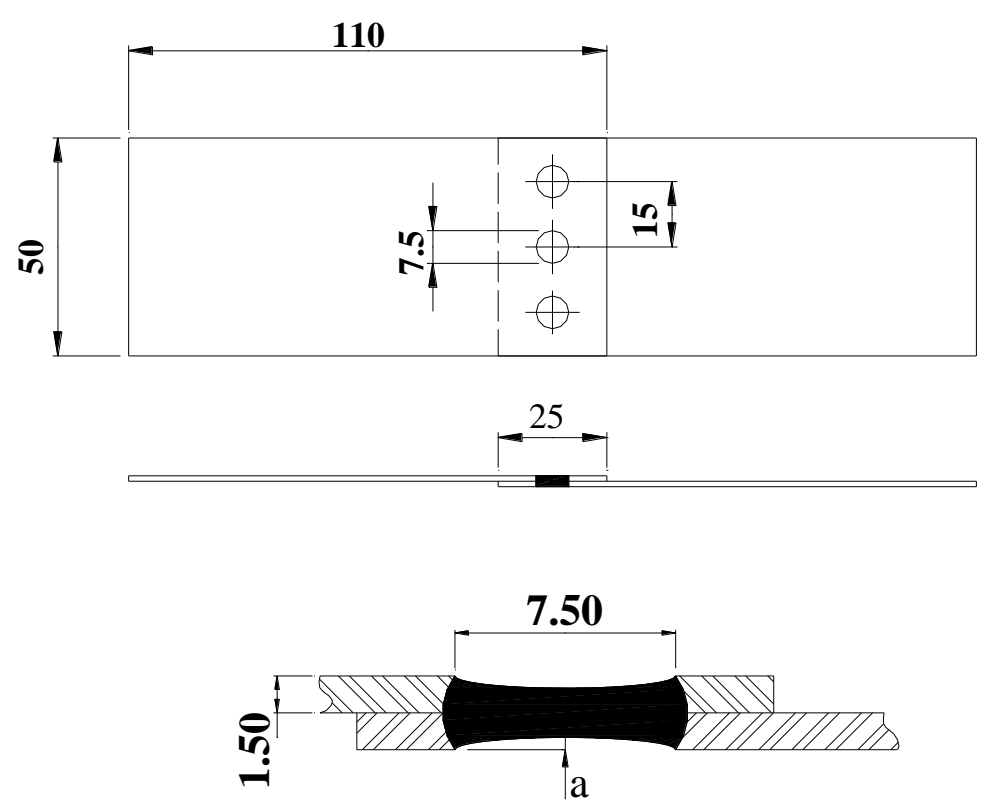

$[\mathrm{mm}]$

Figura 65: Junta soldada em estudo e geometria do ponto ae solaa.

Os parâmetros de soldagem foram alterados com o intuito de se obter dois conjuntos distintos de juntas, quanto à indentação dos pontos de solda. As indentações foram medidas por técnica de ultra-sonografia utilizando um equipamento de inspeção USLT 2000 DP, fabricante Krautkramer, com um 
transdutor de $20 \mathrm{MHz}, 4,5 \mathrm{~mm}$ de diâmetro, com coluna d'água, fabricante Vogt. Após este procedimento, as juntas soldadas puderam ser divididas em dois grupos:

A: juntas onde a indentação não ultrapassou $20 \%$ da espessura das chapas

B: juntas onde a indentação situou-se entre $20 \%$ e $40 \%$ da espessura das chapas

Os dois grupos de juntas soldadas, contendo respectivamente 4 e 6 amostras, foram submetidos a carregamento cíclico controlado pela carga aplicada, que variou de zero a $14 \mathrm{kN}$, com o intuito de se determinar o número de ciclos até a fratura para os dois grupos de juntas soldadas. Tais ensaios foram conduzidos em máquina universal de ensaios MTS, servo-controlada, de $250 \mathrm{kN}$ de capacidade máxima, mostrada na Figura 66. A freqüência de reversão de cargas nos ensaios foi de $8 \mathrm{~Hz}$.

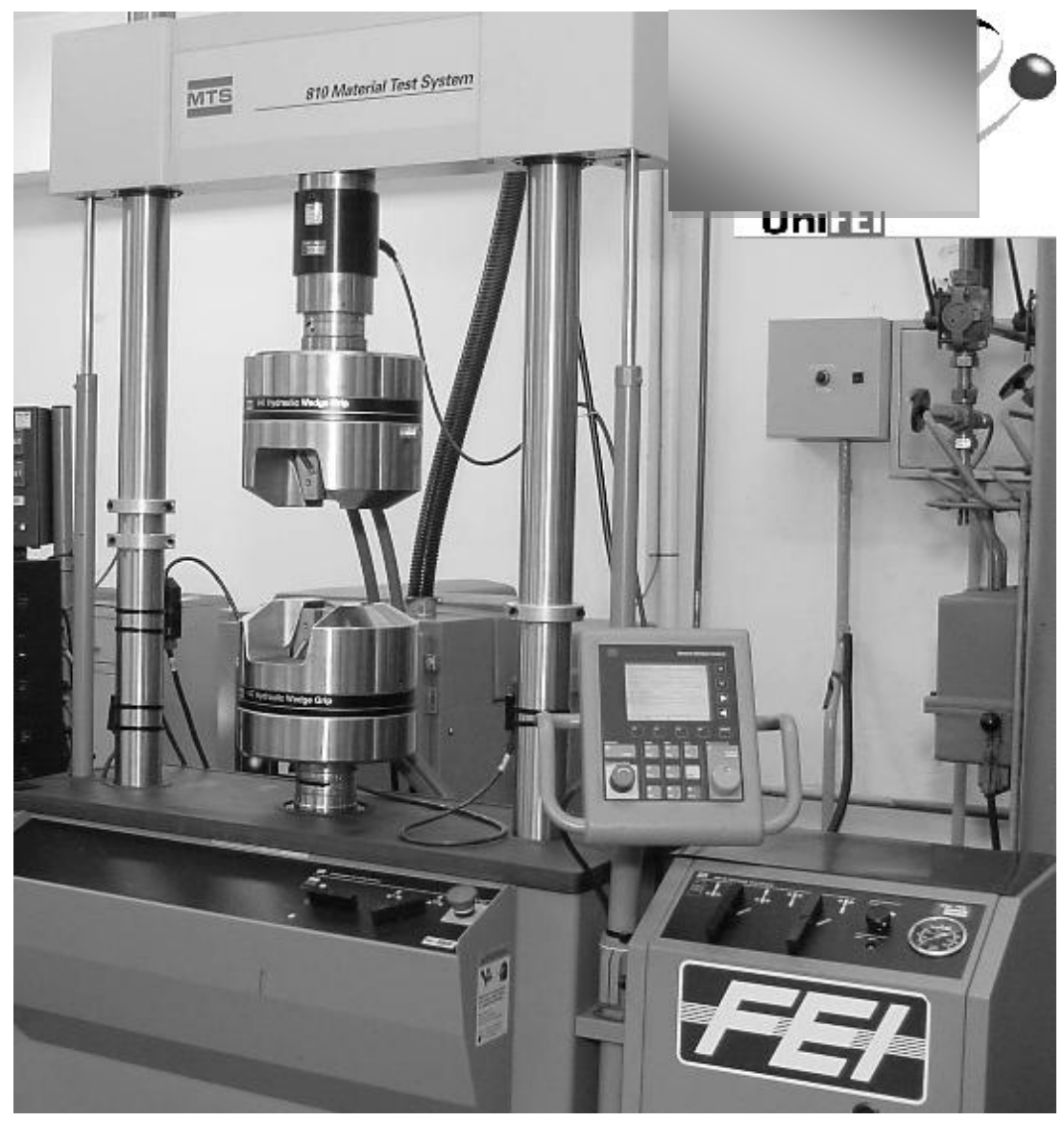

Figura 66: Máquina universal de ensaios MTS do LabMat-FEI. 
A determinação do valor de tensão a ser aplicado na junta estudada foi definido após ensaios de tração realizados no componente, conforme demonstrado nas curvas geradas para 5 amostras aleatórias do grupo estudado, apresentadas na Figura 64.

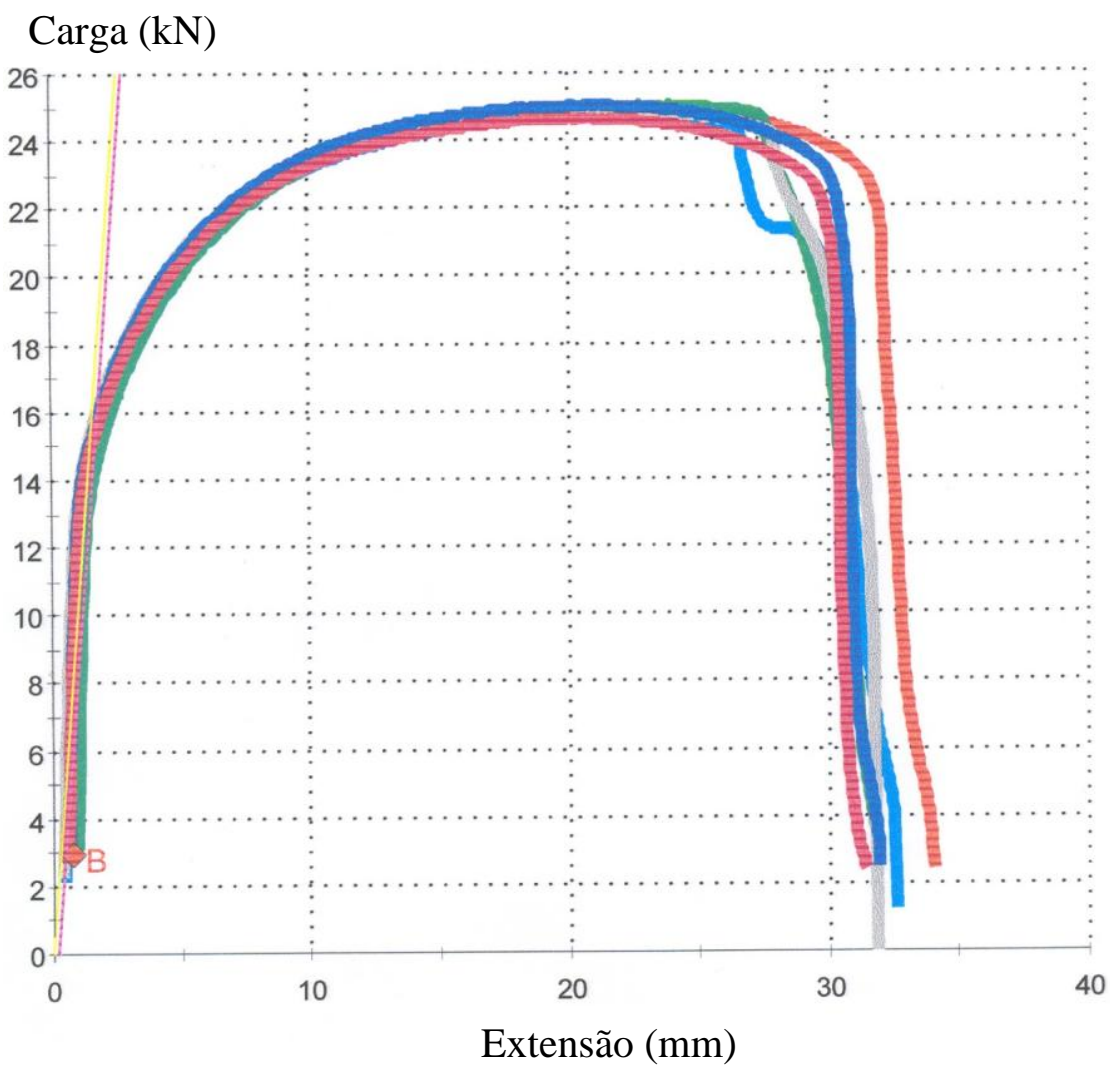

Figura 67: Curva tensão X deformação para as juntas estudadas.

Conforme podemos observar na Figura 67, os valores encontrados para os dois parâmetros de amostras apresentaram resultado semelhante quando submetidos ao ensaio de tração, fato que pode ser explicado devido à geometria da junta estudada, que quando submetida à tração apresenta ruptura no material base, conforme pode ser observado na Figura 68. 


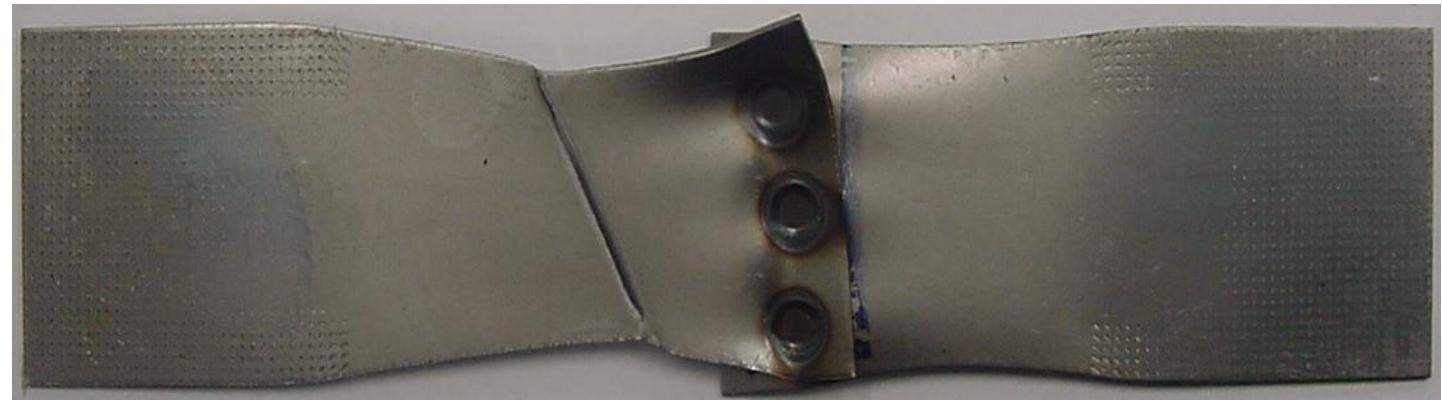

Figura 68: Aspecto do corpo de prova fraturado após ensaios de tração.

Sendo assim, os valores de resistência à tração do componente se situaram em torno de $334 \mathrm{MPa}$, e de acordo com a curva foi possível determinar claramente que o limite de escoamento do componente ocorre por volta da posição de $16 \mathrm{kN}$. Desta forma foi utilizado o valor de carga de $14 \mathrm{kN}$ para assegurar que o ensaio cíclico se realize abaixo do limite de escoamento previsto para o componente.

\subsubsection{Modelamento pelo método dos elementos finitos}

Uma vez que o propósito da análise está em se identificar os pontos críticos de concentração de tensão bem como as amplitudes de tensão resultantes da aplicação cíclica do carregamento, nenhum esforço foi feito no sentido de simular as tensões residuais decorrentes do resfriamento do ponto de solda. Lingren (2001) reporta que, no caso da simulação do processo de soldagem de chapas de aço carbono com $1 \mathrm{~mm}$ de espessura pelo MEF, foram observadas tensões residuais entre -75 MPa e 75 MPa dependendo das condições da simulação.

$\mathrm{Na}$ abordagem do problema de fadiga pelos critérios normalmente empregados de Goodman ou Soderberg, tais tensões residuais representam tensões médias e, uma vez analisadas, podem ser facilmente incorporadas nos critérios acima. No entanto, a simulação do processo de soldagem por ponto envolve a determinação de inúmeros fatores empíricos e, portanto, foge ao escopo deste trabalho. Optou-se, portanto, pela determinação das variações de tensão correspondendo a um carregamento senoidal variando entre 0 e $14 \mathrm{kN}$. Uma vez que ainda é pouco conhecida a influência do amortecimento material no comportamento à fadiga de juntas soldadas, o material foi modelado como viscoelástico linear com 
1,0 \% de amortecimento histerético. A simulação no tempo foi feita utilizando-se 20 pontos por período para uma freqüência de $8 \mathrm{~Hz}$ para um tempo de 0 a $1,25 \mathrm{~s}$, correspondendo a 10 ciclos de aplicação do carregamento.

$\mathrm{Na}$ presente análise, as chapas e os pontos de solda foram modelados utilizando-se elementos sólidos de interpolação quadrática no domínio do tempo com integrador lagrangeano através do MSC-NASTRAN®. Foi feita também uma simulação utilizando elementos planos segundo a técnica spider descrita por Zhang (1999) utilizando elementos rígidos e de viga para simular o ponto de solda. Os resultados desta simulação com parâmetro de malha de $0,8 \mathrm{~mm}$ mostram que a tensão desenvolvida no interior da chapa se concentra, sobretudo ao redor dos pontos externos, fato validado experimentalmente, uma vez que as trincas de fadiga nuclearam próximas as regiões identificadas na análise do MEF como as regiões com a maior concentração de tensões, como mostra a Figura 69. No entanto, os resultados obtidos para a tensão de Von Mises, onde $\Delta \sigma \mathrm{VM}=191.7 \mathrm{MPa}$ e $\sigma$ medVM $=189$ MPa, estão abaixo dos encontrados via simulação com elementos sólidos, embora sigam exatamente a mesma distribuição ao redor dos pontos. Estes resultados estão mostrados nas Figuras 69 e 70. A variação das componentes da tensão principal máxima em função da indentação do ponto de solda com a simulação via elementos sólidos estão apresentados na Figura 71.

Percebe-se que, para níveis de indentação entre $0 \%$ e 15\%, os resultados mostram uma discreta elevação no nível de tensão enquanto que, para uma indentação entre $15 \%$ e $50 \%$ (Figura 71), este aumento de tensão é bem mais acentuado, resultados estes que estão de acordo com os observados por CHAO (2002) para o caso de tensões combinadas. 


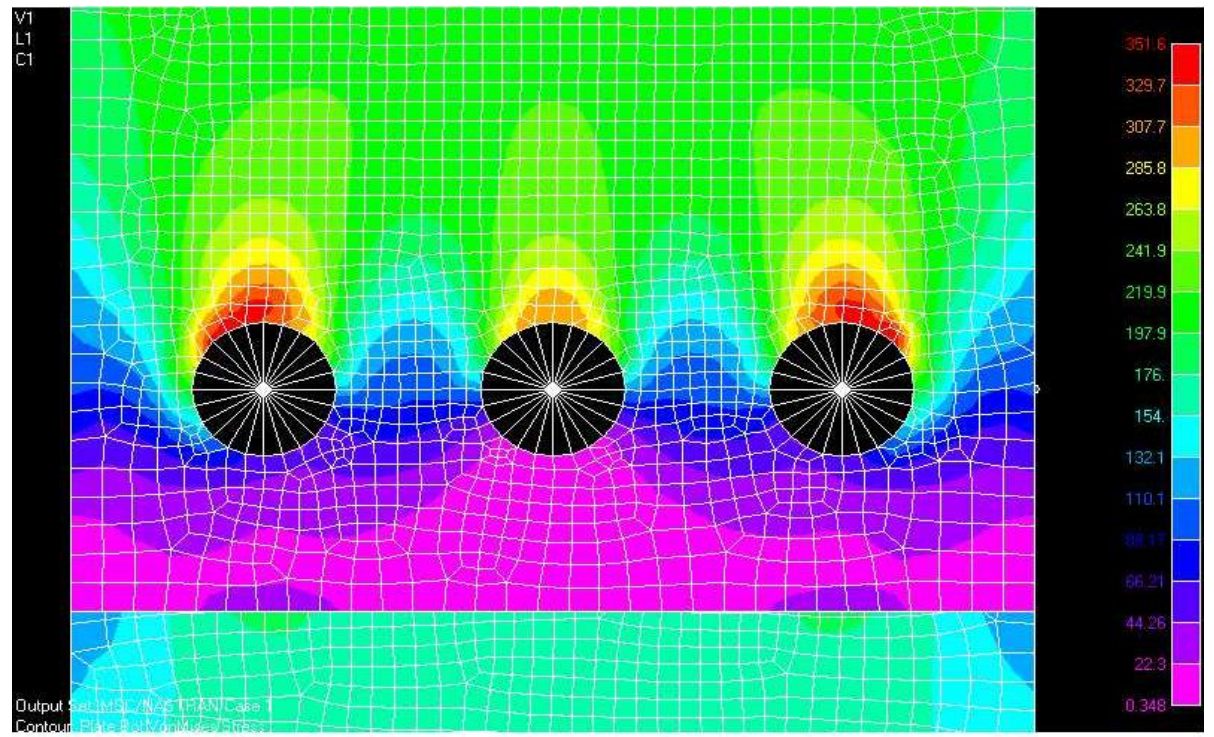

Figura 69: Resultados da simulação via MEF para a tensão principal máxima $(\sigma \max P R=\sigma \operatorname{medPR}+\Delta \sigma \mathrm{PR})$ com elementos planos, mostrando as área de concentração de tensão nos pontos mais externos.

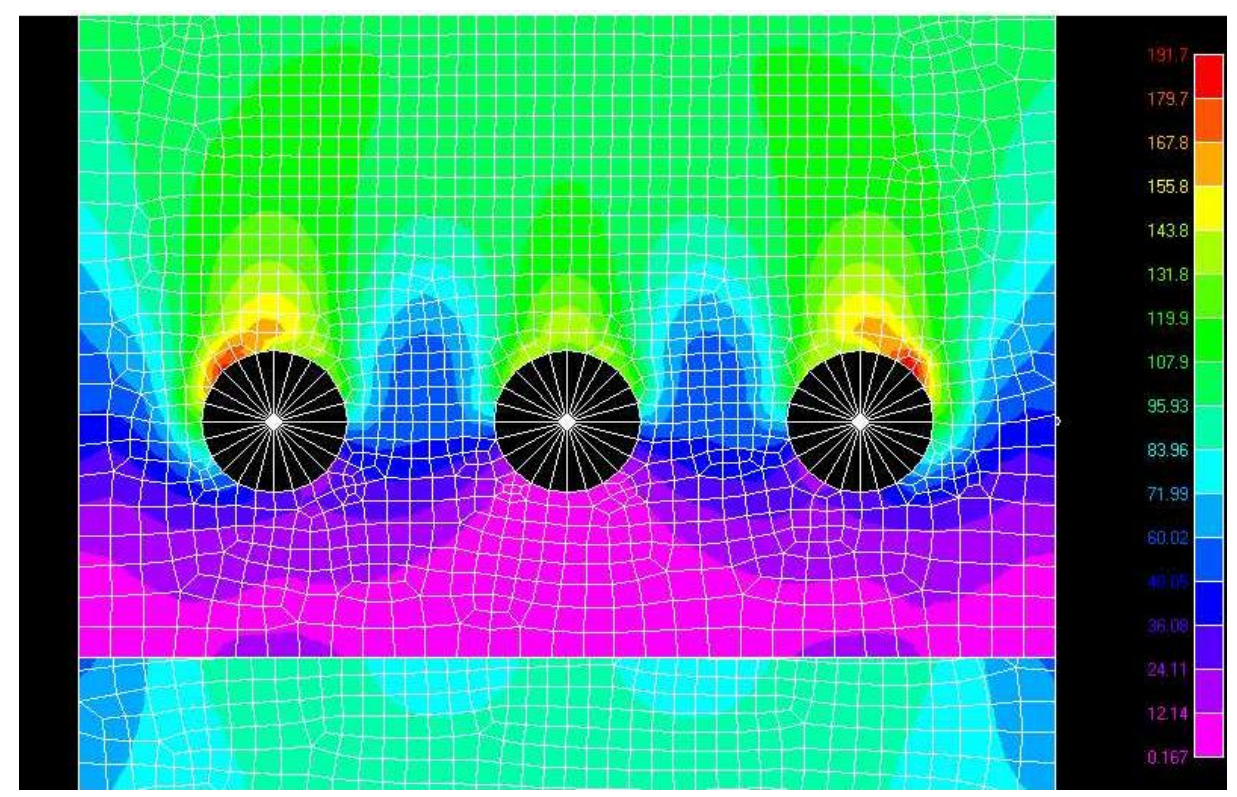

Figura 70: Resultados da simulação via MEF para a tensão de von Mises com elementos planos, mostrando as área de concentração de $\Delta \sigma \mathrm{VM}$ nos pontos mais externos da chapa. 


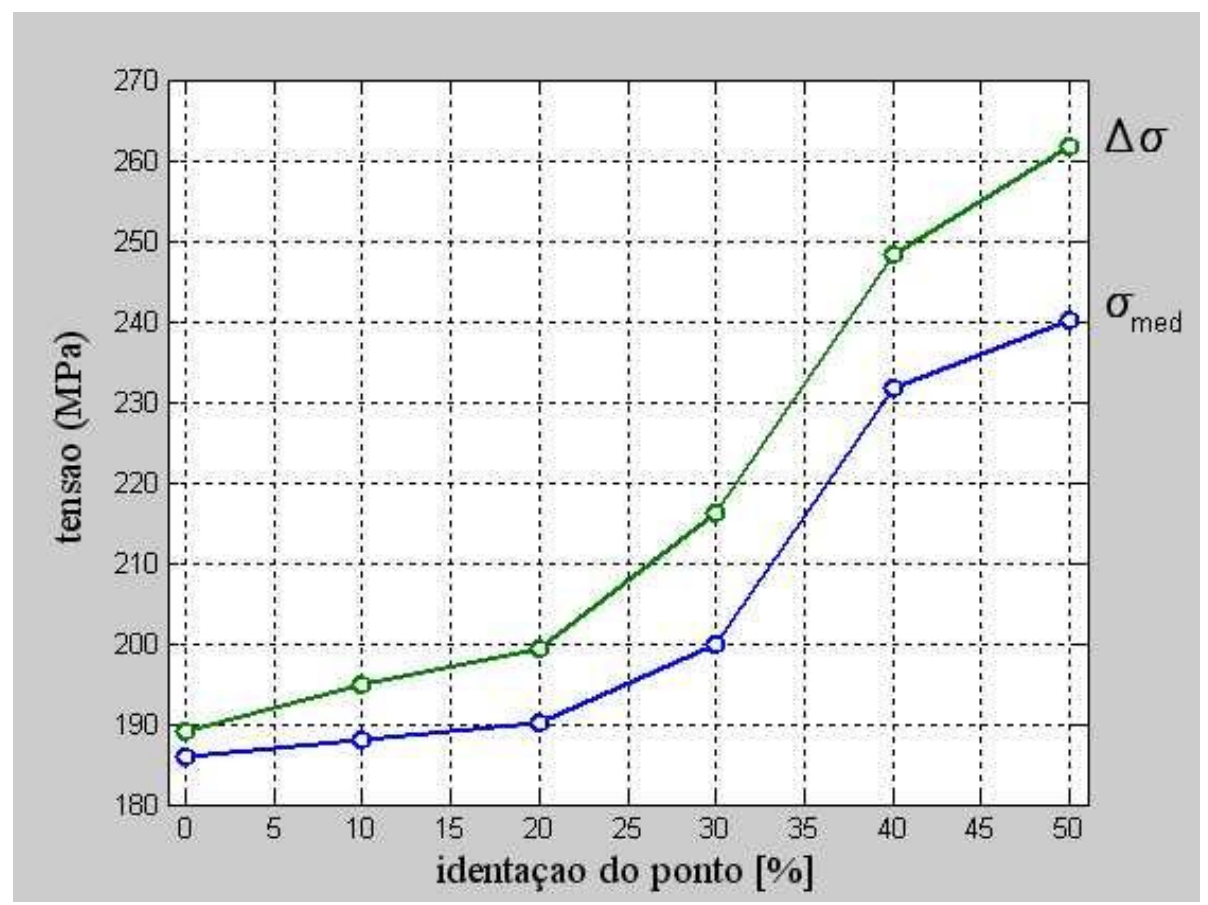

Figura 71: Variação das componentes da tensão principal máxima em função da indentação do ponto de solda. Resultado da simulação via MEF com elementos sólidos.

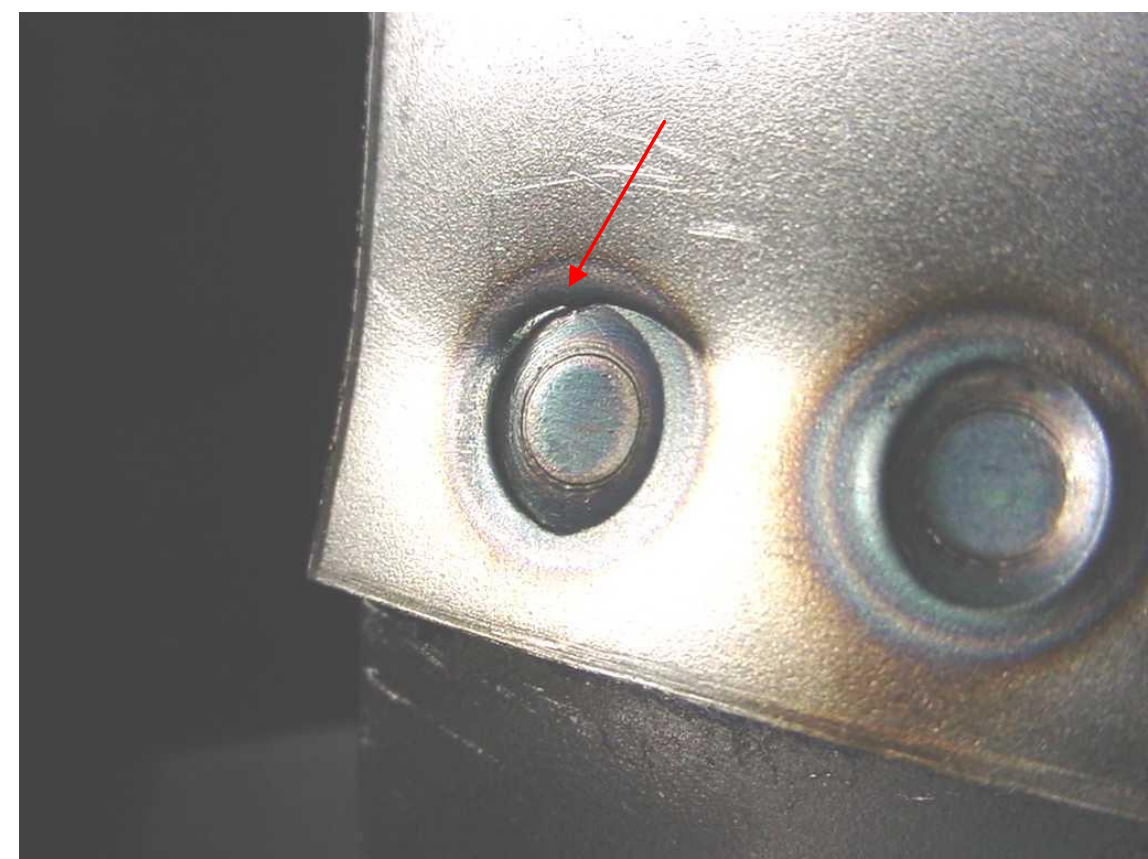

Figura 72: Comprovação experimental: surgimento de trinca na região da tensão de von Mises máxima. 


\subsubsection{Resultados e discussão}

Após os ensaios realizados para os dois grupos de amostras, onde foi registrado o número de ciclos até a fratura do componente, foi possível verificar que a ruptura ocorreu ao redor dos pontos de solda, e não mais no material base, fenômeno constatado após os ensaios de tração. O aspecto do corpo de prova fraturado está demonstrado na Figura 73.

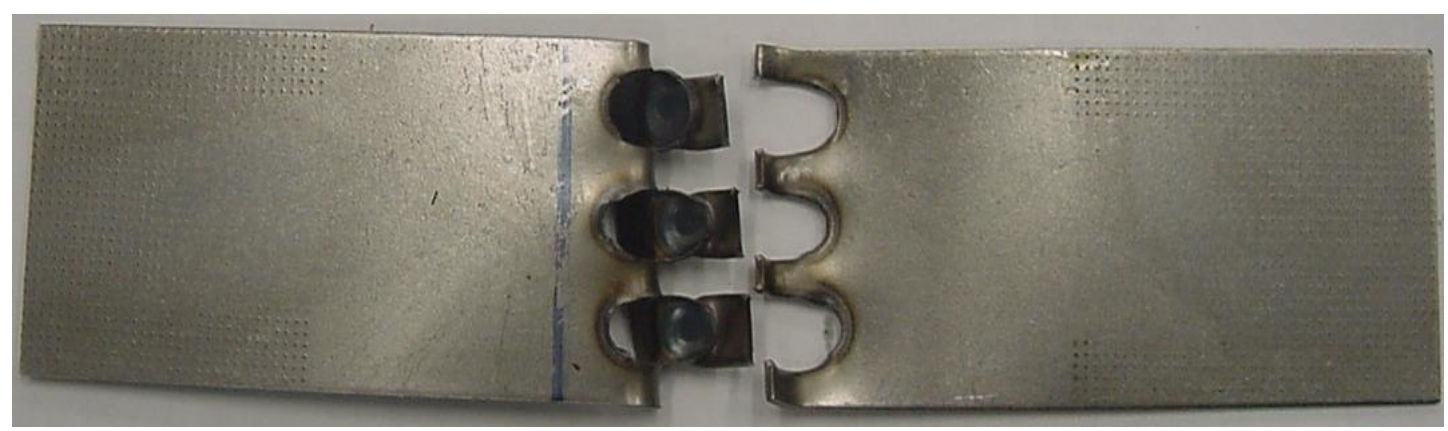

Figura 73: Aspecto do corpo de prova fraturado após o ensaio cíclico.

Buscando a comprovação da efetividade do ensaio realizado, ou seja, se realmente existiu o efeito de fadiga sobre os corpos de prova, foi realizado um ensaio no corpo de prova fraturado através de microscopia eletrônica de varredura, onde foi possível distinguir claramente após o ensaio as regiões de quebra busca do componente, bem como as estrias características de fadiga, conforme demonstrado em detalhes nas Figuras 74, 75 e 76. 


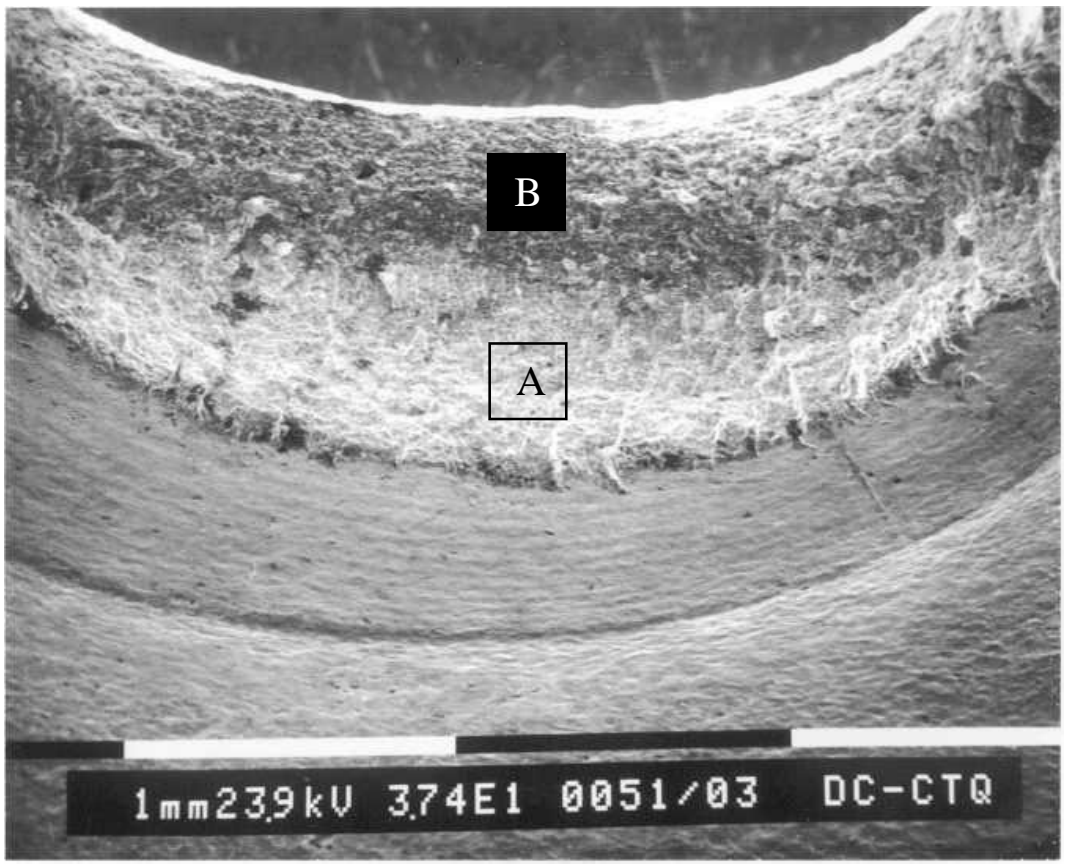

Figura 74: Microscópio Eletrônico de Varredura (MEV) com 37,4 vezes de aumento, onde a região A demonstra a quebra inicial por fadiga, enquanto que a região $\mathrm{B}$ mostra a quebra final brusca.

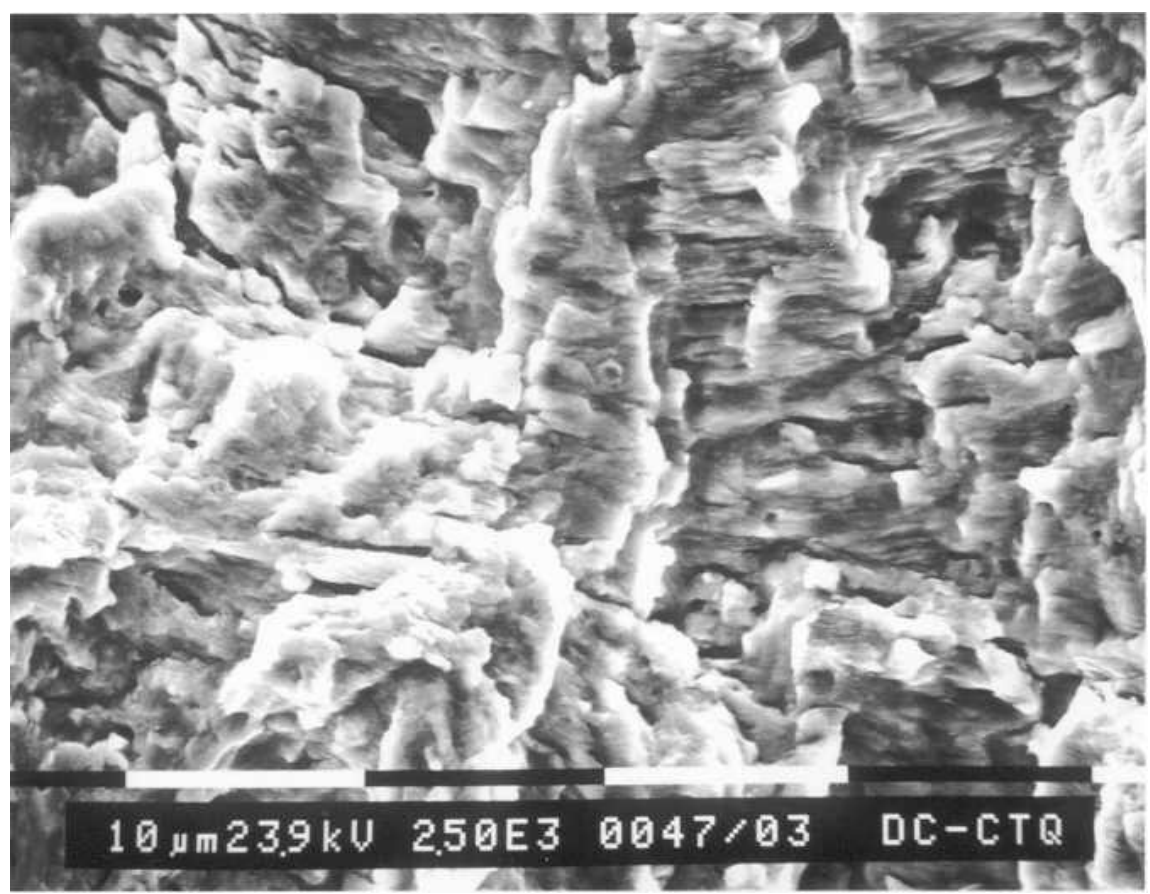

Figura 75: Microscópio Eletrônico de Varredura (MEV) com 2500 vezes de aumento, mostrando detalhe da região A, evidenciando estrias de fadiga. 


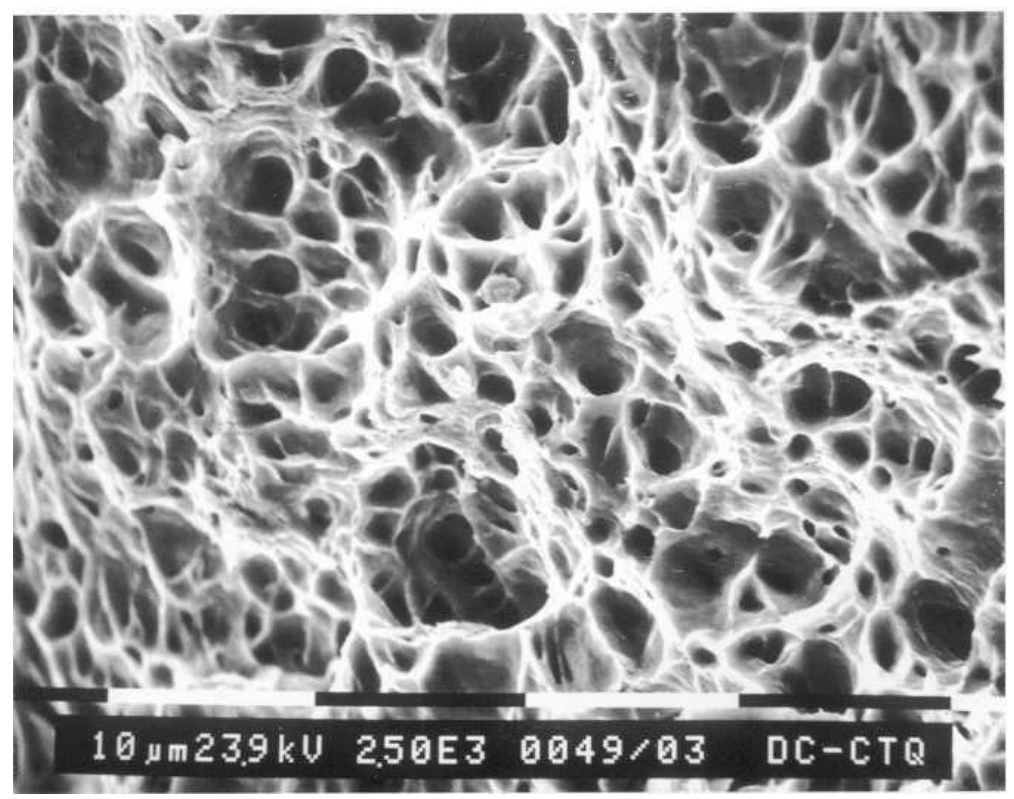

Figura 76: Microscópio Eletrônico de Varredura (MEV) com 2500 vezes de aumento, mostrando detalhe da região B, evidenciando fratura alveolar, característica de uma quebra dúctil.

A Tabela 7.3 traz os valores médios e respectivos desvios-padrão do número de ciclos até a fratura para os dois grupos de amostras, ensaiadas sob amplitude de carga constante, variando-se as cargas mínima e máxima entre zero e 14 kN.

Nota-se que as amostras com indentações de até $20 \%$ da espessura das chapas resultam em vida em fadiga da junta, no carregamento estudado, $30 \%$ maiores que a vida encontrada nas juntas onde a indentação situa-se entre 20 e $40 \%$ da espessura das chapas.

Além disso, nota-se na Tabela 7.3 que o desvio-padrão da vida em fadiga das juntas com indentação de até $20 \%$ equivale a $9 \%$ da vida média, enquanto que para as juntas onde a indentação situa-se entre 20 e $40 \%$ da espessura das chapas o desvio-padrão corresponde a $35 \%$ da vida média. Tais fatos mostram o efeito do aumento da indentação na vida em fadiga dos componentes, e demonstram que o parâmetro utilizado nas medições de ultra-sonografia (aceitar pontos de solda com até $20 \%$ de redução de espessura nominal das chapas) para tais juntas garante melhor segurança no projeto mecânico. 
Tabela 7.3. Valores médios e respectivos desvios-padrão do número de ciclos até a fratura para os dois grupos de amostras, ensaiadas com cargas mínima e máxima de zero e $14 \mathrm{kN}$.

\begin{tabular}{|lc|}
\hline \multicolumn{1}{|c}{ Grupo de amostras } & Vida em fadiga (ciclos) \\
\hline Até $20 \%$ de redução de espessura nominal das chapas & $24663 \pm 2316$ \\
de $20 \%$ a $40 \%$ de redução de espessura nominal das & $18935 \pm 6647$ \\
chapas & \\
\hline
\end{tabular}

Foi possível observar que as trincas de fadiga nuclearam nas regiões de máxima tensão equivalente de von Mises calculada em simulação por MEF, e que a propagação das mesmas se deu na direção da máxima tensão principal também calculada por MEF, conforme mostram as Figuras 65, 66, 67 e 68. É interessante notar um grande aumento na concentração de tensão para os pontos para altos níveis de indentação do ponto.

\subsection{Correlação entre os ensaios de ultra-som 2D, quando comparados ao ensaio de destacamento e aos ensaios metalográficos.}

\subsubsection{Materiais e métodos}

Semelhante ao ensaio realizado o capítulo 7.2, para o experimento foram utilizadas chapas de aço baixo carbono, com espessura variando de 0,8 até $2.0 \mathrm{~mm}$, comumente utilizadas na indústria automotiva. Estas chapas foram sobrepostas e unidas por um único ponto de solda. Os conjuntos soldados formados, bem como o parâmetro de solda utilizado na confecção dos mesmos está listado na tabela 7.4. 
Tabela 7.4. Parâmetros de solda utilizados em cada uma das amostras ensaiadas.

\begin{tabular}{|ccccc|}
\hline \multicolumn{5}{c}{ Parâmetros de solda aplicados em cada amostra } \\
Amostra & Eletrodo & Força & Corrente $(\mathrm{KA})$ & Tempo (ciclos) \\
1 & $\mathrm{R}=25$ & $3 \mathrm{kN}$ & 8,2 & 14 \\
2 & $\mathrm{R}=25$ & $3 \mathrm{kN}$ & 7 & 22 \\
3 & $\mathrm{R}=25$ & $2 \mathrm{kN}$ & 6,5 & 22 \\
4 & $\mathrm{R}=25$ & $2 \mathrm{kN}$ & 6,5 & 10 \\
5 & $\mathrm{R}=25$ & $1 \mathrm{kN}$ & 6 & 10 \\
6 & $\mathrm{R}=25$ & $4 \mathrm{kN}$ & 6,5 & 10 \\
7 & $\mathrm{R}=25$ & $4 \mathrm{kN}$ & 6,5 & 22 \\
8 & $\mathrm{R}=25$ & $4 \mathrm{kN}$ & 8 & 22 \\
9 & $\mathrm{R}=25$ & $4 \mathrm{kN}$ & 11 & 22 \\
10 & Cônico $=6 \mathrm{~mm}$ & $3 \mathrm{kN}$ & 8,2 & 14 \\
11 & Cônico $=6 \mathrm{~mm}$ & $3 \mathrm{kN}$ & 9 & 14 \\
12 & Cônico $=6 \mathrm{~mm}$ & $3 \mathrm{kN}$ & 9,8 & 14 \\
13 & Cônico $=6 \mathrm{~mm}$ & $3 \mathrm{kN}$ & 10,8 & 14 \\
14 & Cônico $=6 \mathrm{~mm}$ & $3 \mathrm{kN}$ & 10,8 & 14 \\
15 & Cônico $=8 \mathrm{~mm}$ & $3 \mathrm{kN}$ & 9 & 30 \\
16 & Cônico $=8 \mathrm{~mm}$ & $3 \mathrm{kN}$ & 7,3 & 30 \\
17 & Cônico $=8 \mathrm{~mm}$ & $3 \mathrm{kN}$ & 6,4 & 30 \\
18 & Cônico $=8 \mathrm{~mm}$ & $3 \mathrm{kN}$ & 8,6 & 40 \\
19 & Cônico $=8 \mathrm{~mm}$ & $3 \mathrm{kN}$ & 8 & 16 \\
\hline 20 & Cônico $=8 \mathrm{~mm}$ & $3 \mathrm{kN}$ & 9,7 & 16 \\
21 & Cônico $=8 \mathrm{~mm}$ & $3 \mathrm{kN}$ & 11 & 40 \\
\hline 22 & Cônico $=8 \mathrm{~mm}$ & $4 \mathrm{kN}$ & 9 & \\
\hline
\end{tabular}

Os parâmetros de solda foram alterados com o intuito de se obter juntas com diâmetros e características diferenciadas, visando aferir a capacidade de detecção do equipamento de ultra-som. As juntas soldadas foram medidas por técnica de ultrasonografia utilizando um equipamento RSWA da Tessonics Corporation com um transdutor matricial de $20 \mathrm{MHz}, 10 \mathrm{~mm}$ de diâmetro. Os parâmetros de medição do equipamento foram ajustados com o intuito de se obter os valores médios do diâmetro estimado da lentilha, com o objetivo de se efetuar uma comparação com os resultados apresentados no capítulo 6, quando demonstrada a técnica de ultra-som utilizando o transdutor matricial. Assim sendo, as medições aferidas com o equipamento se limitaram apenas a tomar os dados de diâmetro, indentação e aspecto visual do ponto em uma determinada altura, proporcionado pela geração de imagens do equipamento.

Posteriormente, os pontos foram destruídos utilizando a técnica de ensaio de destacamento e através de metalografia, como mostrado em capítulos anteriores. 


\subsubsection{Resultados e discussão}

A Tabela 7.5 traz os valores de diâmetro encontrados na medição dos corposde-prova utilizando o equipamento de ultra-som, bem como a respectiva imagem observada na tela do mesmo.

Tabela 7.5. Resultados do ensaio utilizando o equipamento RSWA e respectiva imagem 2D gerada pelo equipamento.

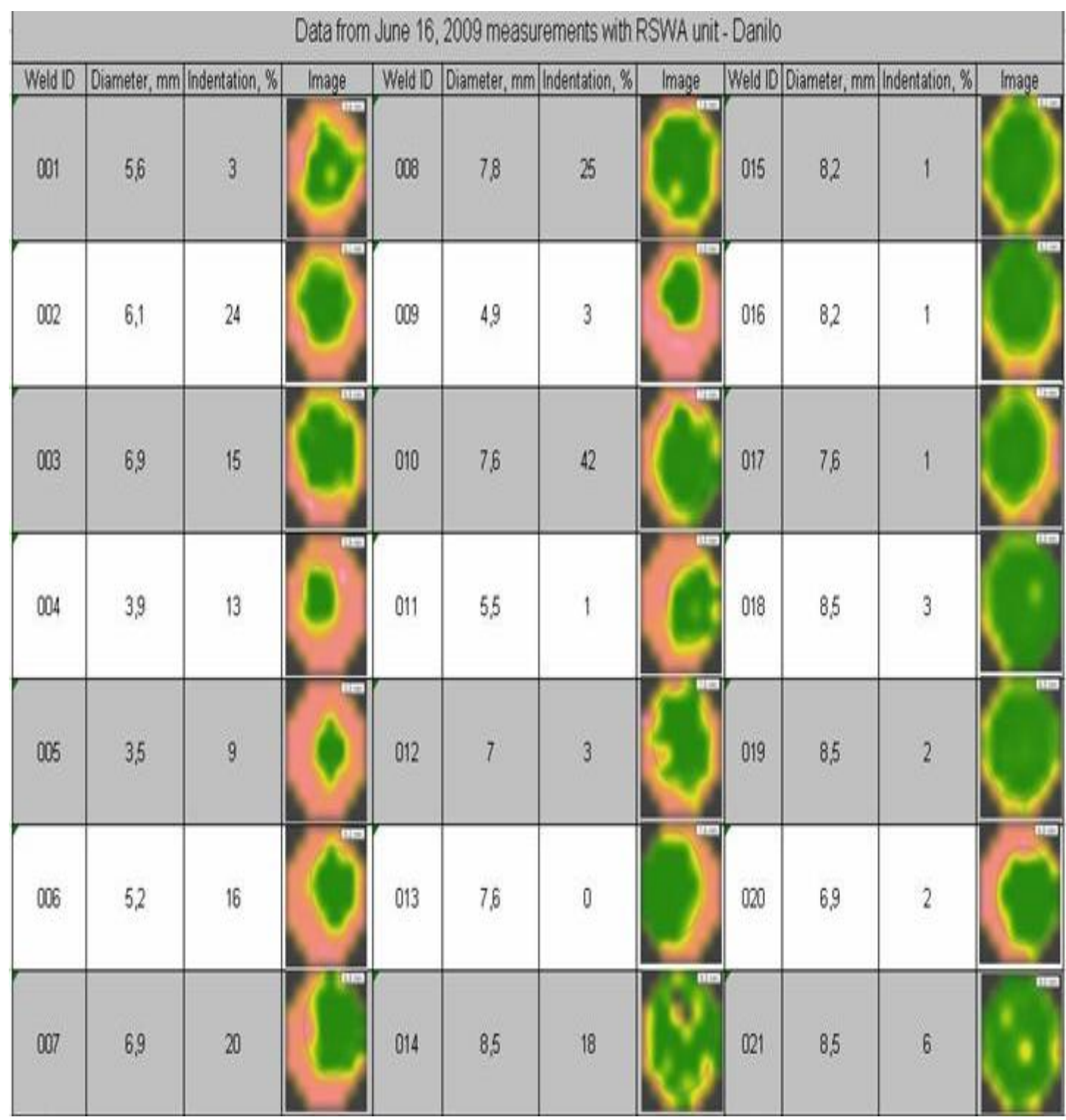

Este resultado foi comparado diretamente com os ensaios destrutivos aplicados, apresentando resultados conforme a Figura 77. 


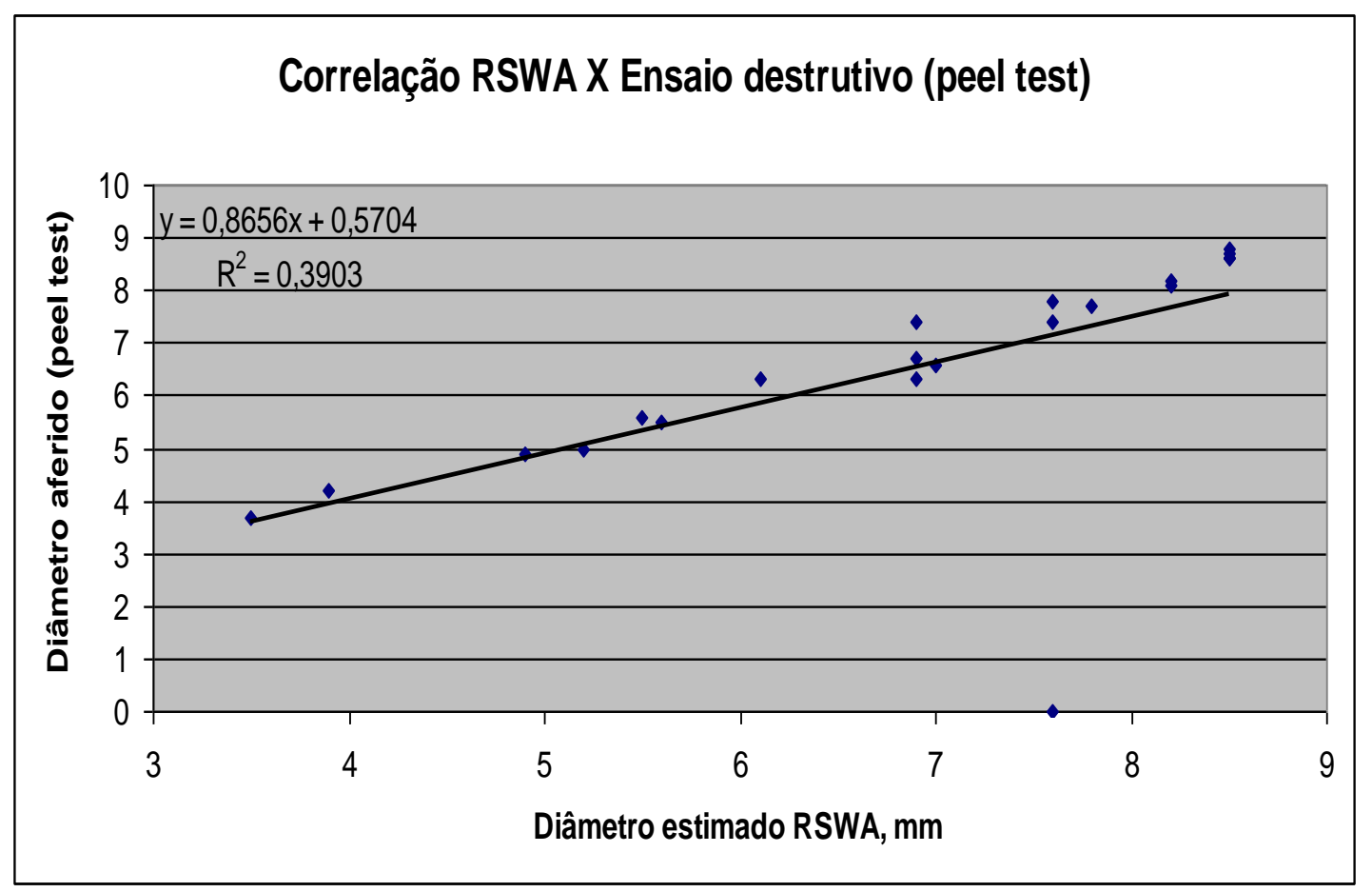

Figura 77: Correlação entre ensaios realizados através do equipamento RSWA x diâmetro aferido durante ensaio destrutivo de martelo e talhadeira.

Nota-se que sob esta avaliação que o valor de $\mathrm{R}^{2}$ não ultrapassou 0,4 , valor muito abaixo aos encontrados no capítulo 6, onde os ensaios efetuados apresentaram valores entre 0,90 e 0,95. Este desempenho baixo ocorreu em especial devido ao fato haver uma amostra que apresentou ruptura durante o ensaio (amostra 10), caracterizando uma ausência total da lentilha de solda, contradizendo a medição de diâmetro inicialmente aferida pelo equipamento. Entretanto, a detecção deste defeito pode ocorrer através de outros parâmetros determinados pelo software do equipamento, como por exemplo, neste caso os valores de indentação da amostra 10 não ultrapassariam 1\%, indicativo de uma penetração da solda não adequada. Estes são indicativos de que um ensaio de correlação conforme apresentada no capítulo 6 não é suficiente para se obter uma avaliação da qualidade de uma determinada junta, sendo necessária a determinação do resultado de parâmetros combinados para que exista uma maior precisão do ensaio. 
Além disso, existem diversos outros parâmetros que podem ser observados nas imagens geradas das amostras que podem ser considerados indetectáveis através do ensaio de martelo e talhadeira, como visto em detalhes nos capítulos anteriores. Um claro exemplo destes fatores pode ser observado na Figura 78, referente a amostras 1 e 8 , e confirmado pelo exame metalográfico demonstrado pela figura 79 .
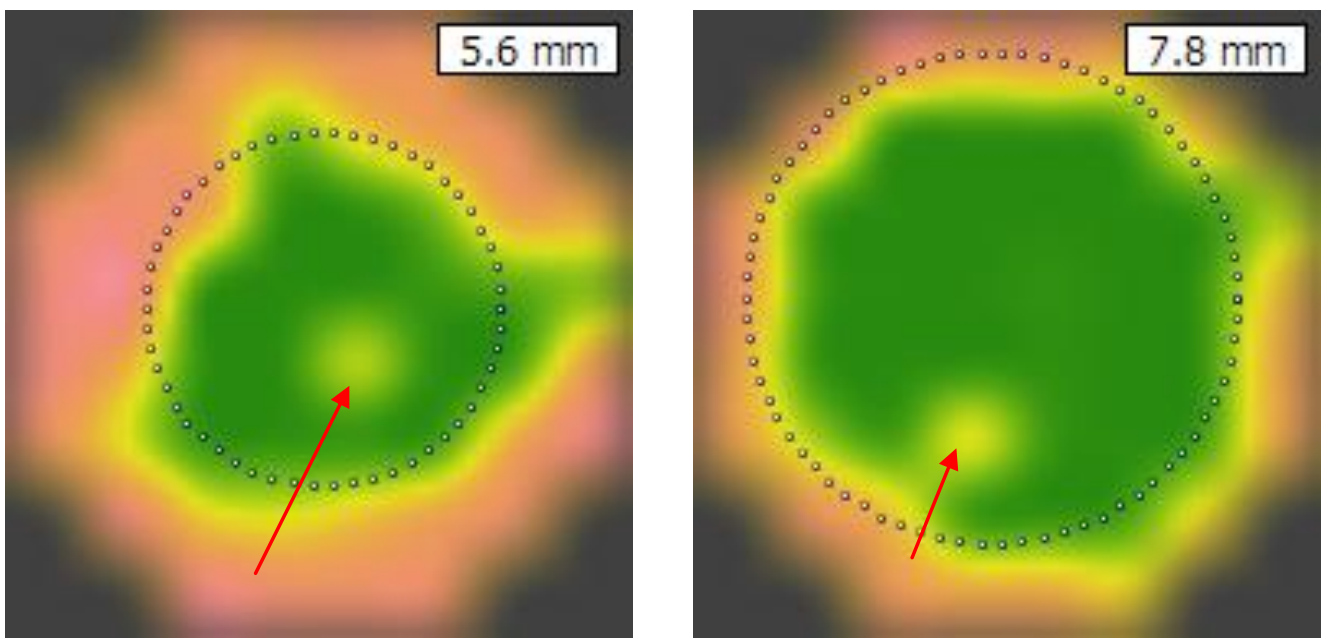

Figura 78: B-scan das amostras 1 e 8, apresentando indicação de provável descontinuidade interna, sinalizadas pelas setas.

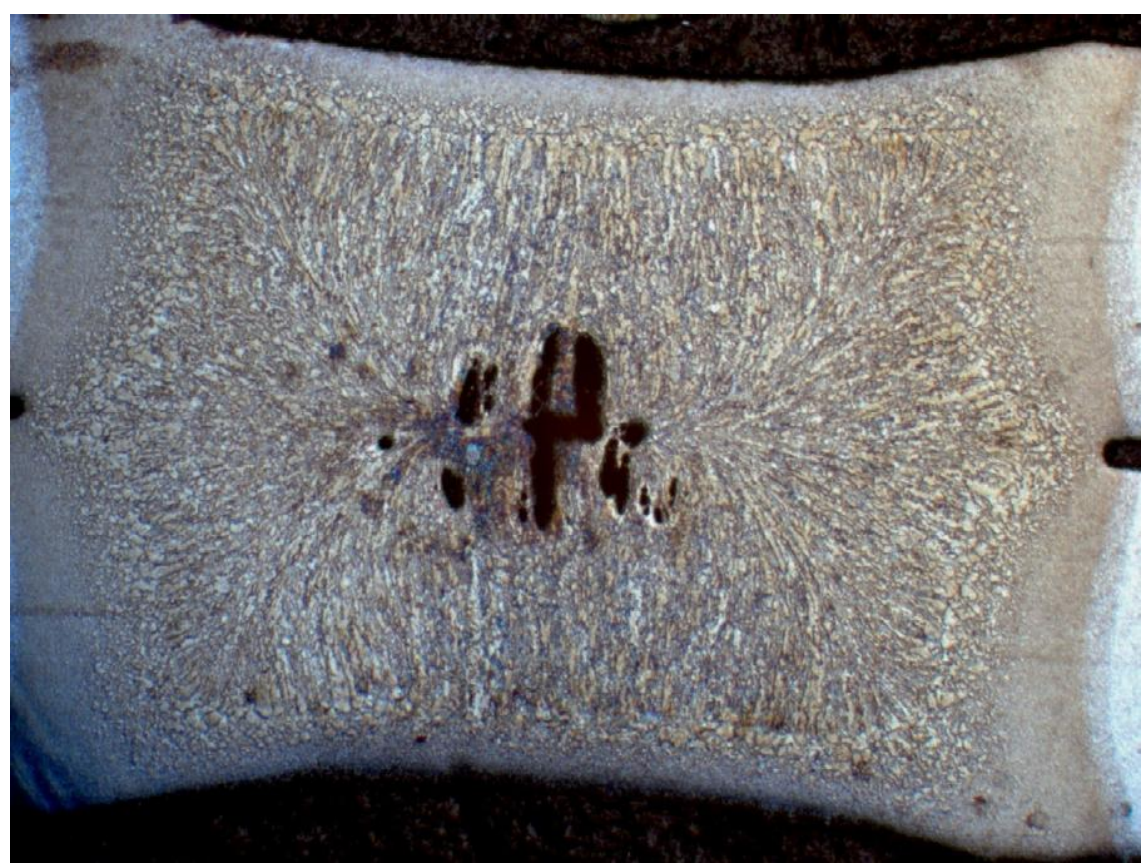

Figura 79: Metalografia da amostra 1, apresentando indicação de descontinuidade interna, confirmando o exame ultra-sônico, $50 \mathrm{X}$ de aumento. 
É importante ressaltar que apesar de o algoritmo auxiliar na avaliação, apenas o manejo correto do transdutor, aliado a uma boa interpretação do operador poderá identificar e interpretar corretamente as imagens geradas pelo equipamento, que de maneira geral é de interpretação muito melhor do que aqueles verificados no ensaio a-scan, demonstrado no capítulo 6 . 


\section{CONCLUSÕES}

Do presente trabalho pode-se concluir que:

- O parâmetro utilizado nas medições de ultra-sonografia - aceitar pontos de solda com até $20 \%$ de redução de espessura nominal das chapas - para as juntas estudadas garante melhor segurança no projeto mecânico, uma vez que a vida média em fadiga é superior nas amostras com esta característica é maior; além disso, tal parâmetro garante menor dispersão na vida em fadiga.

- A técnica de inspeção e controle de solda por resistência a ponto por ultrasom apresenta uma série de vantagens em relação aos ensaios destrutivos convencionalmente utilizados. A medição nos equipamento A - scan e B-scan permitem detectar uma série de indicações anteriormente detectadas somente pelos ensaios metalográficos.

- Embora os ensaios e resultados aqui demonstrados ainda sejam iniciais, a técnica de ultra-som 2D permite aos operadores uma melhor visualização do sinal captado pelo equipamento, em especial devido à aquisição de imagem em tempo real. Resta agora o estabelecimento de parâmetros de monitoramento da técnica, bem como o estabelecimento de normas e procedimentos adaptados a maior sensibilidade deste ensaio.

- Apesar de os algoritmos dos softwares se encontrem em um estágio avançado de desenvolvimento, é fundamental que os operadores dos equipamentos de ultra-som estejam extremamente treinados e familiarizados com a apresentação dos ecos e os demais parâmetros utilizados na avaliação de um ponto de solda, pois como pode ser observada no capítulo 7, a avaliação do diâmetro do ponto automaticamente pelo equipamento não pode ser considerado um bom parâmetro de avaliação, cabendo esta parte a correta interpretação do executor do ensaio. 


\section{TRABALHOS FUTUROS / OPORTUNIDADES}

- Deverão ser estabelecidos parâmetros de monitoramento da técnica, bem como o estabelecimento de normas e procedimentos adaptados a maior sensibilidade deste ensaio;

- A verificação da efetividade da técnica de ultra-som quando submetido ao ensaio com chapas apresentando proteção superficial, uma vez que esta condição não foi abordada neste estudo, embora ensaios práticos demonstram preliminarmente que esta condição não deve ser impeditivo para o ensaio;

- O comportamento do transdutor matricial no ensaio de solda por resistência à projeção, bem como sua aplicação na soldagem por pinos (Stud Weld), o que representa um avanço em relação aos ensaios conhecidos pra esta técnica de soldagem. 


\section{REFERÊNCIAS}

ABEND. "ensaio por ultra-som", Disponível em: $\langle$ http://www.abend.org.br $>$. Acesso em 18 de março de 2008.

ADIS INDÚSTRIA E COMÉRCIO. Catálogos de máquinas, Disponível em: <www.adis.com.br $>$. Acesso em 3 de janeiro de 2005.

ALICH, F. , "Ultraschall - Prüfaufsicht", Daimler Interne Schulungsunterlagen, 2001, Juiz de Fora - MG, p. 1-27.

CHAO, Y.J., "Ultimate Strength and Failure Mechanism of Resistance Spot Weld Subjected to Tensile, Shear, or Combined Tensile/Shear Loads", Journal of Engineering Materials Technology, n.125, p.125-132. 2002

CHERTOV, A. M., NORMAN, J., GAVRILOV, D., MAEV, R. Gr. "Evaluation of Spot Weld Formation as a Function of Degradation and Electrodes Relative Position Using Longitudinal Acoustic Wave Reflection Mode", University of Windsor, 2004

CHERTOV, A.M., R. Gr. MAEV. "Determination of Resistance Spot Weld quality in Real Time Using Reflected Acoustic Waves. Comparison with ThroughTransmission Mode." 16 WCNDT, Montreal, 2004.

DAIMLERCHRYSLER. “Resistance Welding Maintenance Manual”. Detroit, 1999.

DAIMLERCHRYSLER. "Treinamento para operadores de ultra-som em solda a ponto". São Bernardo do Campo, 2002.

DENISOV, A. A., "Modeling and Optimization of Non-Phased 2D Ultrasonic Arrays", PhD thesis, University of Windsor, July 2002.

DENISOV, A. A., "Spot Weld Analysis With 2D Ultrasonic Arrays", J. Res. Natl. Inst. Stand. Technol. 109, 233-244, 2004.

DIETER, G.E. "Engineering Design: A Materials and Processing Approach", McGraw-Hill Inc., New York, USA, 1991.

DIN EN ISO "10447 - Resistance welding - Peel and chisel testing of resistance spots and projection welds", 2006

DIN EN ISO "14329 - Failure types and geometric measurements for resistance spot, seam and projection welds", 2003

FURLANETTO, V. "soldagem por resistência", Instituto de Engenharia de São Paulo, II Soldares, 2004.

GM, “GME 60642-1 - Ultrasonic Testing of Resistance Weld Spots”, 2006

GM, "GMW 14057 - Weld Acceptance Criteria and Repair Procedures Resistance Spot Welds - Steel”, 2006

GM, “QT 001130 - Pressure Welded Joints", 2002

HAIN, R. "Resistivity Testing of Spot Welds Challenges Ultrasonics," Welding Journal, May 1988. 
KAVAMURA, H. A. \& BATALHA, G. F. (2008) "Mechanical strength evaluation for Nd-YAG laser and electric resistance spot weld (ERSW) joint under multiaxial loading", Journal of Materials Processing Technology, V. 201, n. 1-3, p. 507-14.

KAVAMURA, H.A. (2007) "Aplicação de solda laser em carrocerias automotivas : estudo comparativo entre a solda laser e a solda ponto por resistência", 108 p., Professional Master Thesis, Master on Mechanical Engineering of the EPUSP, São Paulo,SP, Brazil. http://www.automotivapoliusp.org.br/mest/banc/pdf/haroldo_akira.pdf

KEARNS, W. H. "Welding Handbook": Resistance and Solid-State Welding and Other Joining Processes. Miami: American Welding Society, 1984.

KOLOSOSKI, J. "Metalografia do Cobre e suas ligas", DaimlerChrysler, 2003

KRAUTKRAMER, J., KRAUTKRAMER, H. "Ultrasonic testing of materials", Springer- Verlag New York, Inc. 1977, 667 p

LANE, J.D. (1987) "Robotic Welding - International Trends in Manufacturing Technology", IFS Publications Ltd., Kempston, ISBN 0-948507-25-X.

LEITE, P. G. P., “Ensaios Não Destrutivos”, ABM: São Paulo, 8.ed., 1977, cap 11.

LINDGREEN, L., "Finite Element Modeling and Simulation of Welding", Journal of Thermal Stresses, n.24, p.141 - 192.

MAEV, R. Gr., CHERTOV, A. M. "Ultrasonic In-Process Monitoring and Feedback of Resistance Spot Weld Quality", submitted to the US Patent Office in June 2004, et al. United States Patent Application 20060076321.

MAEV, R.G., PTCHELINTSEV, A., DENISOV, A. A. "Ultrasonic Imaging With 2D Matrix Transducers", Journal for Material Characterization, Bristol, UK, 25th Intern. Acoustical Imaging Symposium, Mar. 2000, p.326

MANSOUR, T.M., "Ultrasonic Inspection of Spot Welds in Thin-Gage Steel," Materials Evaluation, Vol. 46, No. 4, April 1988, pp. 650-658.

MARIMAX. "Apostila de soldagem". Disponível em: <www.marimax.com.br>. Acesso em 23 de fevereiro de 2005.

MEDAR COMÉRCIO E SERVIÇOS. "Apostila do Treinamento Básico do Processo de Soldagem por Resistência, 2004,

METALURGICA MARIMAX. "Catálogos técnicos", Disponível em: <www.marimax.com.br>. Acesso em 23 de fevereiro de 2005.

MITCHELL, M. R., "Fatigue analysis for design", I Seminário internacional de fadiga - SAE Brasil, 31 de outubro de 2001, São Bernardo do Campo - SP, p. 1-29.

ROGEON, P, CARRE, P., COSTA, J., SIBILIA, G., SAINDRENAN, G. "Characterization of electrical contact conditions in spot welding assemblies", Journal of Materials Processing Technology, Disponível em: <www.elsevier.com/locate/jamtprotec >. Acesso em 23 de junho de 2007 
ROSSI, G.P. (2007) "Correlation Study of Spot Welded Specimens' Behavior Using Finite Element Method", Master Thesis on Mech. Engineering EPUSP, SP, Brazil.

RSWA USER'S MANUAL. Disponível em: <www.tessonics.com>. Acesso em 3 de fevereiro de 2009.

SAE, "SP-1621 - Fatigue and Failure of Spot Welds and Weld Joints", 2001

SENAI, “Soldagem”, 5ª Edição, SãoPaulo - Brasil, Senai , 1997, p. 130.

STOCCO, D., BATALHA, G.F. "Characterization of electric resistance spotweld main defects by ultrasonic inspections and their metallographic interpretations", $3^{\circ} \mathrm{COBEF}$, São Pedro, Brazil, 2007

STOCCO, D., GONÇALVES, R. "Caracterização dos defeitos encontrados em solda a ponto utilizando a técnica do ultra-som, apoiado à exames metalográficos)", $3^{\circ}$ PANNDT, Rio de Janeiro, Brazil, 2003

STOCCO, D., GONÇALVES, R., BARROS, R. M., "Analysis of spotweld joints by ultrasonic inspection, FEM and residual stress measurements", $16^{\circ}$ WCNDT, Montreal, 2004

STOCCO,D, MAEV, R Gr., CHERTOV, A.M., BATALHA, G.F.. "Comparison between in - line ultrasonic monitoring of the spot weld quality and conventional NDT methods applied in a real production environment". $17^{\circ}$ WCNDT, Shangai, 2008

SURESH, S., "Fatigue of materials", Cambridge Press:Boston, 2. ed., 1998, cap. 4.

T. OKUDA, M. INADA, "Ultrasonic testing method and apparatus for resistance welding," U.S. Patent 4,099,045, Nov. 29, 1976.

VARGAS, J. E., "Estudo da Formação, Geometria e Resistência do Ponto na Soldagem por Resistências: Uma Abordagem Estatística". Dissertação de Mestrado em Sistemas Mecatrônicos", Publicação: DM-05/2006, Departamento de Engenharia Mecânica, Universidade de Brasília, Brasília, DF, 143p - 2006.

WAINER, E., "Soldagem - Processos e metalurgia", Edgard Blücher:São Paulo, 1995, p. 217-242.

WELDING DESIGN \& FABRICATION, "RW Spot Welds Sound Good," Vol. 60, March 1987, pp. 67-68.

WELDING DESIGN \& FABRICATION,"UT Measures Spot-Weld Quality,"Vol. 61, July 1988, p 24.

ZHANG, S., "Stress Intensities derived from stresses around a spot weld", International Journal of Fracture, n.99, p. 239-247. 